Portland State University

PDXScholar

1993

\title{
State Policy and Public Administration Impacts on an Emerging Industry: The Wine Industry in Oregon and Washington
}

Anthony Gene White

Portland State University

Follow this and additional works at: https://pdxscholar.library.pdx.edu/open_access_etds Let us know how access to this document benefits you.

\section{Recommended Citation}

White, Anthony Gene, "State Policy and Public Administration Impacts on an Emerging Industry: The Wine Industry in Oregon and Washington" (1993). Dissertations and Theses. Paper 1291.

https://doi.org/10.15760/etd.1290

This Dissertation is brought to you for free and open access. It has been accepted for inclusion in Dissertations and Theses by an authorized administrator of PDXScholar. Please contact us if we can make this document more accessible: pdxscholar@pdx.edu. 


\title{
STATE POLICY AND PUBLIC ADMINISTRATION \\ IMPACTS ON AN EMERGING INDUSTRY: THE WINE INDUSTRY \\ IN OREGON AND WASHINGTON
}

by

ANTHONY GENE WHITE

A dissertation submitted in partial fulfillment

of the requirements for the degree of

\author{
DOCTOR OF PHILOSOPHY \\ in \\ PUBLIC ADMINISTRATION AND POLICY
}

Portland State University

1993 
TO THE OFFICE OF GRADUATE STUDIES:

The members of the Committee approve the dissertation of Anthony Gene White presented November 4, 1993.

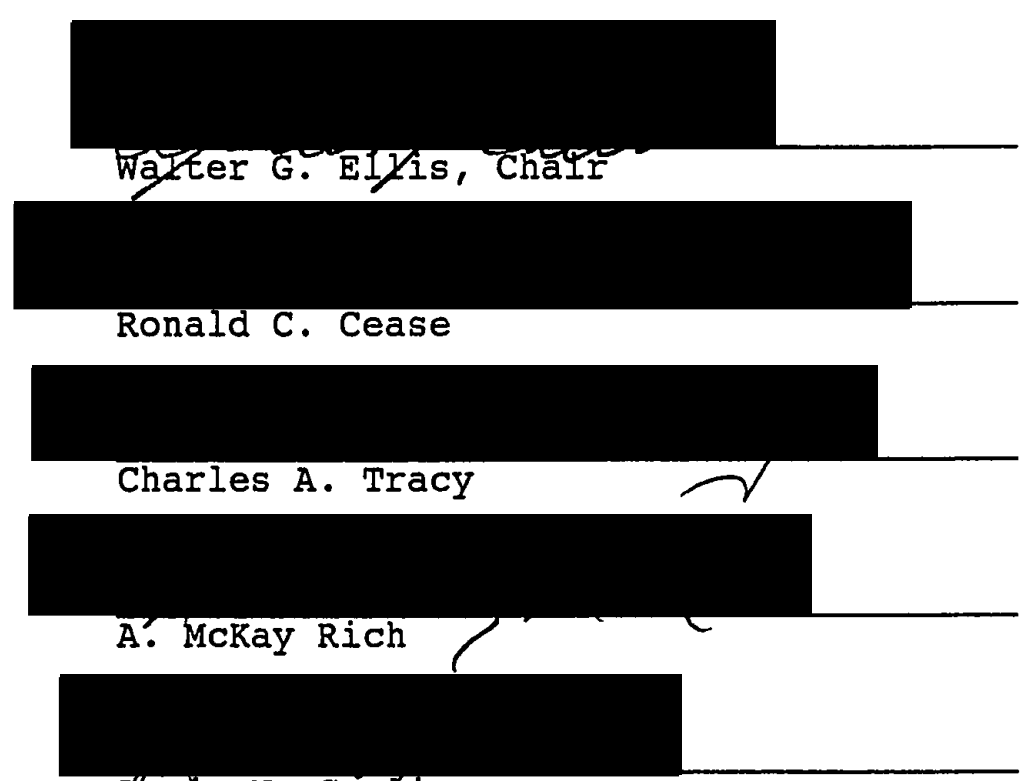

Ilew is N. Gosin

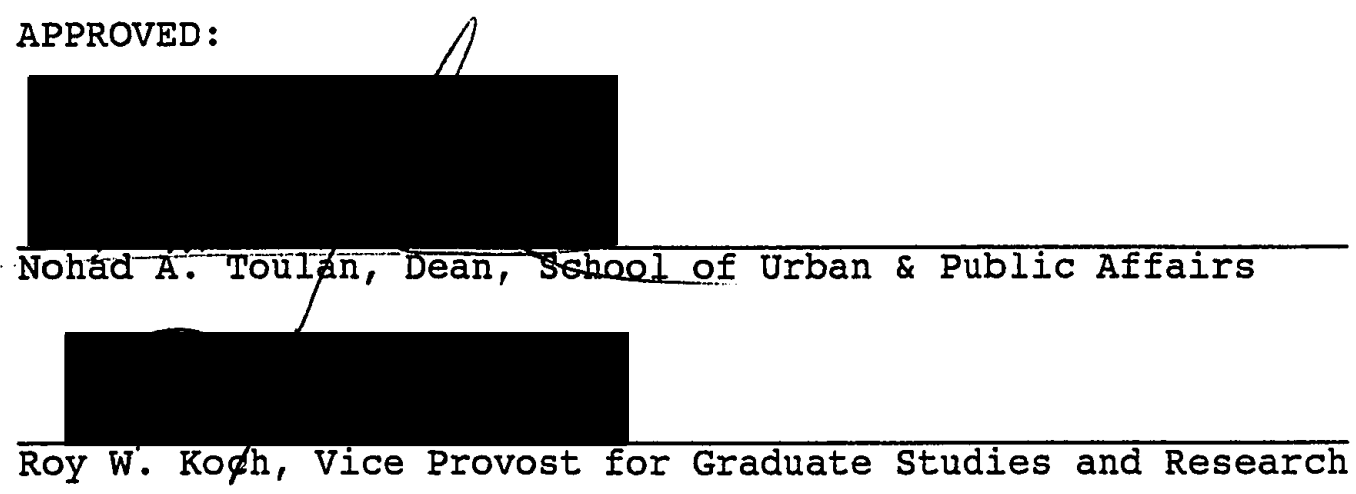


AN ABSTRACT OF THE DISSERTATION OF Anthony Gene white for the Doctor of Philosophy in Public Administration and Policy presented November 4, 1993.

Title: State Policy and Public Administration Impacts on an Emerging Industry: The Wine Industry in Oregon and Washington

APPROVED BY THE MEMBERS OF THE DISSERTATION COMMITTEE:

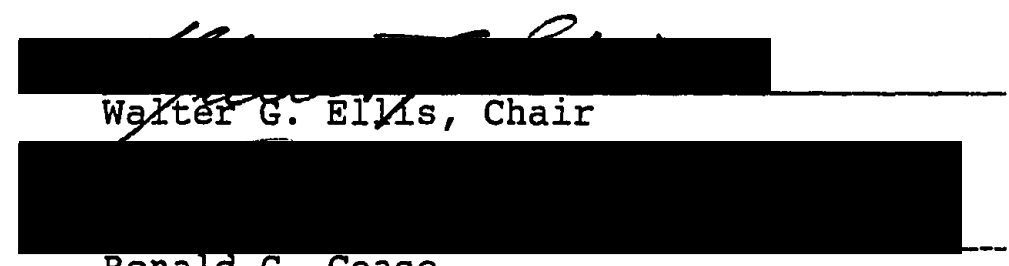

Ronald C. Cease

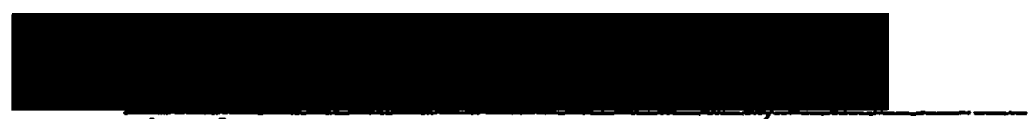

Charles A. Tracy

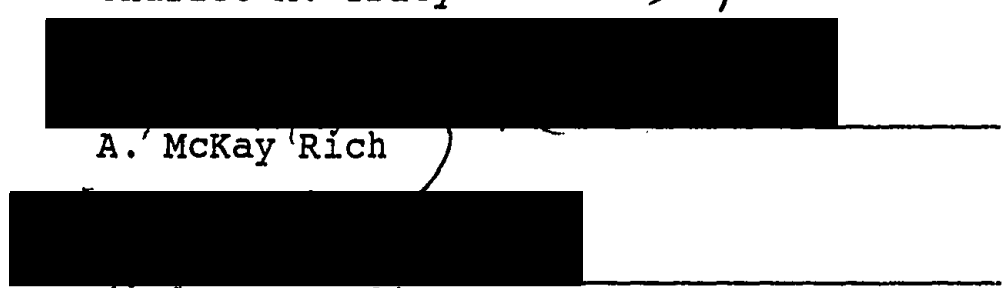

hewils N. Goslin

Oregon and Washington state administrative agencies' impacts on economic development within the winery industry are examined. Policy cluster development appears to impact economic development programs differently in each state. 
The wine industry has flourished in both states since 1970, yet Oregon with 608 of Washington's population supports 108 more wineries. Oregon winery numbers continue to grow while Washington's seem to have leveled out.

From the literature and industry interviews, three variables were selected to be tested for their industry impacts: (1) domestic consumption (state population times wine industry per-capita consumption); (2) market domination (estimated from interviews and proportional market share); and (3) net government intervention, an outgrowth of policy cluster analysis (policies cannot be examined in isolation, but must consider the impacts of direct and indirect collateral state agency policies as well).

Comparisons between states were made. Multiple regression analysis determined these three variables accounted for approximately $95 \%$ of the variability of numbers of Oregon and Washington commercial wineries. Different equations were derived for each state.

of the three variables, Oregon's number of wineries appears to be more influenced by government policy than in Washington. In Washington domestic consumption has more impact on winery numbers than in oregon. No substantial impacts of oligopoly could be determined in either state. 


\section{ACKNOWLEDGEMENTS}

The author gratefully acknowledges the help and suggestions of the disseration committee, both individually and collectively. Additionally, the unique group of women and men who are winemakers, winery owners and managers, vineyard masters, and tasting room employees has contributed materially to the shape of this research.

Individually, several people have provided invaluable assistance or counsel, or just listened and nodded at the appropriate times. These include: Bill and Virginia Fuller of Tualatin Vineyards, Lincoln and Joan Wolverton of Salishan Winery, Pat and Joe Campbell of Elk Cove Winery, and Tom and Wendy Kreutner of Autumn wind Winery.

Finally, the author is indebted to, and acknowledges the contributions of his wife, Carole Ann White, without whose thoughtful insights, palate, culinary skills, and navigational talents this work would never have been brought to completion.

Anthony G. White

Fall 1993

West Linn, Oregon 
TABLE OF CONTENTS

PAGE

ACKNOWLEDGEMENTS . . . . . . . . . . . . . . . . iii

LIST OF TABLES . . . . . . . . . . . . . . . . vi vi

LIST OF FIGURES. . . . . . . . . . . . . . . . . . vii

CHAPTER

I INTRODUCTORY OVERVIEW. . . . . . . . . . . . I

General Considerations. . . . . . . 1

Business/Legal Background . . . . . . 3

State Government Comparison . . . . 6

Policy Considerations . . . . . . . 7

wine in the Northwest......... . 9

Economic Development Policy . . . . . 10

Policy/Analysis Questions . . . . . . 13

I I REVIEW OF THE LITERATURE . . . . . . . . . 16

State Entrepreneurship. . . . . . . 17

Relevant Public Policy in the Northwest. 20

Wine and Its Impacts. . . . . . . . 36

Oregon Wine History . . . . . . . . 37

Washington Wine History . . . . . . . 40

III CONTEXT. . . . . . . . . . . . . . . 4 46

Definitions . . . . . . . . . . . 46

Public Policy . . . . . . . . . . 47 
Public Policy Clusters. . . . . . 50

Cultural Comparisons. . . . . . . 51

Political Comparisons . . . . . . . 54

Structures of State Governments . . . 56

Economics of Wine . . . . . . . . 59

Summary . . . . . . . . . . . 65

IV DESCRIPTION OF THE MODEL . . . . . . . . . 70

Initial Data. . . . . . . . . 71

Methods and Techniques. . . . . . . 78

Time Frame. . . . . . . . . . 78

Variables . . . . . . . . . . 79

V OBSERVATIONS . . . . . . . . . . . 83

Winery Data . . . . . . . . . 83

Variable Data . . . . . . . . 83

Analysis. . . . . . . . . . 86

VI CONCLUSIONS AND RECOMMENDATIONS. • . . • . . 97

Commentary. . . . . . . . . . 97

Interpretation. . . . . . . . . . 98

Conclusions . . . . . . . . . 102

Cautions. . . . . . . . . . 107

Recommendations ......... 108

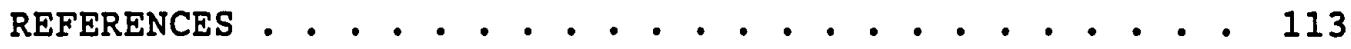

GLOSSARY . . . . . . . . . . . . . . 138 


\section{LIST OF TABLES}

TABLE

PAGE

I Alcoholic Beverages . . . . . . . 8

II Components of the wine Industry . . . . . 11

II State Administrative Agency Function Area

Centralization/Decentralization, 1970-1990 . . . . . . . . 35

IV Wineries in Oregon, 1970-1993 . . . . 39

V Wineries in Washington, 1970-1993 . . . 44

VI State Administrative Agencies and Their

Assistive Impacts on the Wine

Industry, 1970-1990...... . 66

VII State Administrative Agencies and Their

Restraining Impacts on the wine

Industry, 1970-1990... . . . 67

VIII Commercial Wineries in Oregon and

Washington. . . . . . . . 74

IX Collected/Processed Data, Oregon and

Washington wine Industries. . . 85

$\mathrm{X} \quad$ Industry Differences, Oregon and

Washington. . . . . . . . 87

XI Oregon Industry Regression Summary. . . . 93

XII Washington Industry Regression Summary. • 95 


\section{LIST OF FIGURES}

FIGURE

PAGE

1. Policy Development . . . . . . . . 50

2. Policy Cluster . . . . . . . . . 51

3. Per Capita Wine Consumption. . . . . . . 71

4. Wineries in Oregon and Washington. . . . . 75

5. Washington Wineries as Time Series.. . . 90

6. Oregon wineries as Time Series . . . . . . 91 
Well can ye mouth fair Freedom's classic line. And talk of Constitutions o'er your wine. ${ }^{1}$

\section{GENERAL CONSIDERATIONS}

Governments spend money to develop and implement policies. Inevitably, questions arise in this spending. Who is to make the policy -- voters, legislators, special interests, bureaucrats -- or all of the preceding? What is the money to be spent on? Can it be spent, if indeed it should be spent, effectively?

What goes wrong, or right, when government develops policies and spends money on matters many believe should be left solely to the marketplace? Why do single governments, the states of America, seem to battle within themselves in developing and carrying out some policies? How can two adjacent states, created from a common territory and history, with similar legal/governmental structures, arrive at different results in carrying out basically the same policy?

\footnotetext{
'Thomas Campbell, on Poland, Vol. 1, at 65.
} 
Public administration, although practiced for millennia by governments throughout the world, is still a field still "under construction," a fermenting vat whose ultimate results are still unknown. ${ }^{2}$ Competing views, techniques, values and philosophies often obscure the underlying reasons why things happen the way they do. In America, where many value systems may come into play, the application of techniques such as the "scientific method" to public administration - and especially policy development analysis - may become hopelessly entangled. ${ }^{3}$

It is not the intent of this discussion to evaluate various techniques of policy analysis. However, it is notable that there are other techniques of approaching and analyzing various issues in public administration, and that the ones utilized herein are not free of controversy.

${ }^{2}$ Robert H. Simmons and Eugene P. Dvorin, Public Administration: Values, Policy, and Change (Port washington, NY: Alfred Publishing, 1977), Chapter 1; Edward V. Schneier (Ed.), Policy-Making in American Government (New York: Basic Books, 1969), pp. ix-xii. Public administration, as a field, is far younger and less well-developed than its cousin, business administration.

3M.E. Hawksworth, Theoretical Issues in Policy Analysis (Albany, NY: State University of New York Press, 1988), p. 4. Hawksworth argues that empiricism and the scientific method, as proposed by "positivist philosophers of science" (at 38, et seg), is flawed inasmuch as "carefully controlled, neutral observation of empirical events" is not possible in the human experience. See also H.M. Blalock, Causal Models in the Social Sciences (Chicago: Aldine, Atherton, 1971). 
BUSINESS/LEGAL BACKGROUND

Imbedded within the U.S. Constitution ${ }^{4}$ are the requirements that the federal and state governments should not interfere with any person's life, liberty or property without due process of law. Just what kind and level of interference should be avoided changes over time and is unclear; the U.S. Supreme Court has never been willing to put a clear definition on what "due process" is necessary at any one point in time. 5

From the 1780's through the $1870^{\prime} \mathrm{s}$, the scale of business activity and economic policy in America was generally too small to raise concerns about government interference, the most notable exceptions being the Whiskey Rebellion of 1794 and the development of the transcontinental railroads. Business usually did as it wished with little or no hindrance from state and local governments with no administrative resources to bring to bear, little or no interest in such matters, ${ }^{6}$ and an overriding desire after

\section{${ }^{4} \mathrm{U} . \mathrm{S}$. Constitution, Amendments $\mathrm{V}$ and XIV.}

${ }^{5}$ James MacGregor Burns and Jack Walter Peltason, Government by the People (Englewood Cliffs, NY: Prentice-HaIl, 1963), 5th Edition, p. 186.

${ }^{6}$ See, for example, Marshall E. Dimock and Gladys 0 . Dimock, Public Administration (New York: Holt, Reinhart and winston, 1964), Chapter 2, for a discussion of the historical perspective on public administration. 
1865 to recover from the devastation of the Civil War.

It was not until the $1880^{\prime}$ 's that the U.S. Supreme Court began substituting its judgments for those of elected officials, formalizing and codifying the policies of laissez faire, or "hands-off."7 within the context of a "weak state" relative to business, government did not perceive its role as actively regulating business, but rather as being subordinate to capital. ${ }^{8}$ As Burns and Peltason explain, - . The Supreme Court from about 1880 to 1937 was composed for the most part of conservative gentlemen who considered almost all social welfare legislation unreasonable and hence contrary to substantive due process . . . elevating the doctrine of laissez faire into a constitutional principle, vetoed laws adversely affecting property rights unless the judges could be persuaded that such laws were absolutely necessary to protect public health or safety."

However, it was also during this period that

countervailing forces were heralding the twilight for

laissez faire, as described by Joseph zimmerman:

- . (1) change in the methods of manufacturing from the small shop in which the owner worked with a few hands to the giant corporation with tens of thousands of employees; (2) change from a primarily local distributing system to one that is primarily concerned with national and international markets; (3) popular demands for governmental protection against the overweening power of big business and big labor; and (4) development of increased social

${ }^{7}$ Ibid. p. 18; see also Burns and Peltason, op cit., p. 187 and Joseph F. Zimmerman, State and Local Government (New York: Barnes \& Noble, 1962), p. 207.

${ }^{8}$ Peter Eisinger, The Rise of the Entrepreneurial state (Madison, WI: University of Wisconsin Press, 1988), p. 81.

${ }^{9}$ Burns and Peltason, Op cit., p. 187. 
consciousness." 10

Business thus began facing increasing regulation from circa 1880, although a regulation which together with a substantive infrastructure was intended to be supportive ${ }^{11}$ rather than suppressive.

In recent decades, cycles of recession, expansion, and inflation placed strains on state tax bases and unemployment insurance. The national economy shifted from an emphasis on manufacturing and resource exploitation to a service base. As federal administrations sought to extricate themselves from financing state activities, the need to have a diversified economic foundation became clear to many state officials. State governments found themselves in the 1960's and 1970's competing with one another for new businesses.

Oregon and washington were no different; their primary economic emphasis of the 1960's and 1970's was utilization of natural resources such as agriculture, forestry, energy and fisheries. Energy intensive industry such as aluminum smelting could take advantage of the region's inexpensive electric power, supporting the aircraft industry.

Dawning on both states was a need to diversify; oneeconomy states seem to be hit harder and longer in a recession, especially when that economy is centered around

\footnotetext{
${ }^{10}$ zimmerman, op cit., p. 207.

${ }^{11}$ See Eisinger op cit., p. 5; John zyman, Governments, Markets and Growth (Ithica, NY: Cornell Press, 1983), p. 19.
} 
basic industry such as home building, or aircraft building for transportation and defense.

\section{STATE GOVERNMENT COMPARISON}

Before considering some of Oregon and washington state agencies' policy-making structures, it is noted that both states have similar governmental structures. Unsurprising: the two states are neighbors, and were created from the same Oregon Territory; physical, economic and political issues arise within similar time contexts; and their major constitutional provisions are very similar to one another.

In fact, due to this similarity, the central puzzle of this investigation arose. How can two states, so similar in history, climate, geology, geography, and governmental structure have the same industry grow within their borders in different ways? Are purely economic forces supplanted or enhanced by something else?

In the next chapter, when attention is turned to the actual state governmental structures, observe that the same issues are addressed by agencies of almost identical names, sizes and relationships to the overall bureaucratic structure. ${ }^{12}$

$$
\text { POLICY CONSIDERATIONS }
$$

${ }^{12}$ In fact, such similarities suggest an answer; if the agencies are the same, there must be some internal bureaucratic differences that reflect how policy is made and executed in how these agencies relate to the new, emerging wine industry. 
Among the premier controversial policy topics in 20 th century United States is the role of alcohol, its use, and its impacts. For some, drinking alcoholic beverages is self destructive, and the moral issue of allowing others to deliberately intoxicate themselves, to lose control of absolute sobriety and mental control, is inflammatory.

The U.S. Constitution, America's principal policy document, has been twice amended to address public policy relative to alcohol. ${ }^{13}$ Thousands of Americans died or were imprisoned during the era called "Prohibition," in the battle to control the trade in alcoholic beverages ${ }^{14}$-including wine. What is wine, and why should it have policy impacts?

wine -- the fermented juice of fruits, especially grapes -- is one of the oldest processed beverages known to humankind, some found to be over 5,400 years old. ${ }^{15}$ Any pulpy fruit containing natural sugars, exposed to wild

${ }^{13} \mathrm{U} . \mathrm{S}$. Constitution, Articles XVIII and XXI.

${ }^{14}$ David E. Kyvig, Repealing National Prohibition (Chicago: University of Chicago Press, 1979), pp. 74-75, 111-112, 122123. Estimates based upon three years' statistics from one city, Chicago, where the body count directly attributable to Prohibition was 375 (1923-26).

${ }^{15} \mathrm{John}$ N. Wilford, "The Earliest Wine. . .," New York Times, 140 (April 30, 1991), p. BI. 
yeasts present in the air, will produce wine ${ }^{16}$ without any human intervention. One must add preservatives to, or otherwise treat, fruit juices to prevent wine formation. Wines fall within the middle of the range of alcoholcontent beverages, as shown in Table $I$.

TABLE I

ALCOHOLIC BEVERAGES ${ }^{17}$

$\begin{array}{llc}\text { Beverage } & \text { Source } & \text { \&Alcohol by Volume } \\ \text { Beers } & \text { Hops, Malt } & 28-68 \\ \text { Wine, Unfortified Grapes; Fruit } & 68-148 \\ \text { Wine, Fortified } & \begin{array}{l}\text { Unfortified wine } \\ \text { Grains }\end{array} & \text { approx } 258 \\ \text { Liquor } & 15 \%-1008 \\ \text { In terms of policy impacts, the existence of alcoholic }\end{array}$
beverage production as an industry within a state develops many issues in many policy areas:

(1) land use;

(2) agriculture;

(3) health;

(4) social services;

(5) economic development;

Each of these policy areas is briefly examined in the literature review of the next chapter, as they relate to the impacts they impose on Pacific Northwest wine industries.

${ }^{16}$ See John Arlott, Wine (New York: Oxford" University Press, 1974); Gerald Asher, on Wine (New York: Random House, 1982); and other general texts on wine and wine-making.

${ }^{17}$ The definitions will vary according to source. See Revised Code of Washington Annotated (RCWA), Title 66 . 
WINE IN THE NORTHWEST

By the 1840's the Pacific Northwest was occupied and operated as a part of the British Empire under the Hudson's Bay Company. The Treaty of 1846 relinquished control of what was then the Oregon Territory to the United States government. This area encompassed what is now Oregon, Washington, Idaho, and parts of Wyoming and Montana. Oregon entered the Union first, in 1859, followed in 1889 by Montana and Washington and in 1890 by Idaho and Wyoming. Grape growing has a long tradition in the Oregon Territory. By the mid-1820's, grapes were grown near Fort Vancouver, on the Columbia River, probably planted by Hudson's Bay employees. As one writer reports, - . vines (were) planted at Fort Walla Walla by French settlers before the arrival of Marcus Whitman - these vines may predate the first plantings in the Napa Valley . . . a commercial winery operated in the Walla Walla valley in the 1860's and $1870^{\prime} \mathrm{s}$. . Grapes were also among the crops planted by settlers in the fertile willamette valley in the middle of the nineteenth century, although most of these were probably table grapes. The 1860 census reports 2,600 gallons of wine produced in (Oregon) . . . (by) 1880 ... Jackson County . . was producing 15,000 gallons of wine a year. By 1890 there was a commercial winery in the Umpqua Valley, near Roseburg . . ."18

No records from this era survive to tell of Territorial or State government involvement in aiding or regulating the developing wine industry.

${ }^{18}$ Corbet Clark, American Wines of the Northwest (New York: William Morrow and Company, 1989), pp. 39-40, 45. 
With the passage of the Volstead Act ${ }^{19}$, most commercial wineries in the Pacific Northwest were put out of business. The few survivors made kosher wine for religious ceremony. With the repeal of Prohibition ${ }^{20}$, a number of new wineries sprang up in both states. Most failed to survive into the $1960^{\prime} \mathrm{s} .{ }^{21}$ It was into the mid- and late-1960's when both states saw a rejuvenation of the wine industry.

\section{ECONOMIC DEVELOPMENT POLICY}

Within the late $1960^{\prime}$ s and early 1970's the various states recognized that careful economic development was necessary to attract and retain citizens, increase tax revenues, and maintain a positive and healthy environment. One question that required immediate attention was, "What constitutes an industry?" After all, it is industry that comprehensive economic development policies try to develop. For the purposes of this discussion, a "business" is any organization (corporation, partnership, sole proprietor) providing goods and/or services to customers for the principal reason of making a profit for its owner(s). An 1920 .

${ }^{19} \mathrm{U} . \mathrm{S}$. Constitution, Article XVIII, effective January 16, 1933. ${ }^{20}$ U.S. Constitution, Article XXI, effective December 5,

${ }^{21}$ Clark, op cit., pp. 40-41. Those that did survive this span included the predecessors of Ste. Michelle in Washington and Honeywood in Oregon. 
"industry," on the other hand, is a group of interrelated businesses that produce, distribute and sell the same or similar types of goods and services, including the economic infrastructure required for existence and those complementary businesses needed for increased efficiency or market effectiveness. 22

In the case of the wine industry, at the least, it consists of those components listed in Table II.

TABLE II

COMPONENTS OF THE WINE INDUSTRY

Sector

Agricultural

Manufacturing

Marketing
Components

Vine-growers/sellers Grape growers/Vineyards Bio-technical innovators Fertilizer/insecticide developers Bird chasers Labor suppliers

Vine equipment: screening, trellises Winery equipment makers, sellers and repairers: vats, crushers, presses, barrels, etc.

Glass producers

Post-production

Bottlers

wholesalers

Negotiants

Distributors

Retailers

Books and publications: authors, producers, graphic artists, copywriters, photographers

winery-specific accessories: glasses, shirts, aprons, posters, calendars

${ }^{22}$ These and other business sector definitions are adapted from those in Douglas Greenwald, The McGraw-Hill Dictionary of Modern Economics (New York: McGraw-Hill, 1965). 
TABLE II

$$
\begin{gathered}
\text { COMPONENTS OF THE WINE INDUSTRY } \\
\text { (continued) }
\end{gathered}
$$

\section{Sector}

Service

Others

\section{Components}

Real estate specialists

Accountants

Attorneys

Business/financial planners

Tour designers and conductors

Tour transportation

Festival/event designers/coordinators

Specialty hotels and inns

Seminars/work-shops

Formal and informal education providers

Artisans/craftspeople specializing in wine-related items

Note that this brief list does not include governmental agencies. As an industry, the wine industry can at some times (e.g., the Pacific Northwest during the $1800^{\prime} \mathrm{s}$ ) and in some countries (South America) does operate, sell, produce, and distribute without any direct government involvement. ${ }^{23}$ Indirectly, however, the wine industry relies (as do other industries) on the existence of an underlying infrastructure provided by government. This infrastructure consists in part of: a common currency, regulated and backed by government; a system of roads and bridges; a postal system; communications; and protection in the form of police

${ }^{23}$ There are always indirect effects that are in evidence. For example, the viticulture research and education program of the University of California at Davis, while performed in California, contributes knowledge, vines, and wine makers to both Oregon and washington throughout much of the $1900 \mathrm{c}$. 
and fire services against certain hazards and risks.

Clearly, the economic magnitude of the wine industry in just one state is the result of far more than that of 100 wineries, but of thousands of businesses and entrepreneurs. Some are located out of state, and may not contribute directly to state tax revenues. Many are privately held and do not reveal their finances, and thus data is unavailable. Many devote only a small part of their overall business to the wine industry, so that economic differentiation is not possible.

A substitute measure for the whole industry, such as the number of wineries in commercial operation, will be needed in any evaluation. Unfortunately, any such measure will by necessity be coarse, and lose fine detail data.

\section{POLICY/ANALYSIS QUESTIONS}

Some significant policy questions arise from state governments' involvement in private enterprise activity: [a] why become involved in a potentially controversial activity such as making and selling alcoholic beverages, and once choosing to be a proponent (from an economic development standpoint): [b] how and why do state government agencies and policies -- in particular Oregon and Washington -differ from ore another in achieving successful growth of that industry?

Specific policy questions that are investigated in this 
exploration include:

[1] What does the literature say, pro and con, about government support of an industry that may contribute to social ills? Does the public administration literature provide some clues to which states and agencies might be more instrumental than others in enhancing or retarding economic development?

[2] What variables should be considered by public managers to most effectively help in encouraging the growth of a new, start-up industry?

Specific analytical questions investigated herein are perhaps more focused as a result of the two policy questions:

[3] Is the number of commercial, operating wineries in a state in any one year directly related to the policy-relevant state administrative agencies' expenditures on wineries?

[4] Are there identifiable market variables, and what are their relative impacts, which might be directly related to the number of commercial, operating wineries in a state in any one year? [5] Are the relationships of [3] and [4], if any, the same from one state to another? Answers to these questions lie in what a comparative study can show about the interrelationship between market 
forces and public entrepreneurial forces in the development of a new, start-up industry. How, and how well, state agencies react internally and interact with one another in such policy implementation may also point the way to development of a multi-policy theory.

To bring some analytical structure to bear on these questions, multiple approaches are utilized. To address the first question, an in-depth literature search and analysis is employed.

To evaluate the remaining four question, a statistical model is developed which examines the growth of the wine industry in both states, Oregon and Washington, in light of: the market for the product; market domination by participants; and changing influence(s) of state government policies and actions. The usefulness of such a model is evaluated both in explanatory and predictive terms.

Finally, the literature search and model analysis are considered in the light of interviews with principals in the Northwest wine industry, associated persons, and government officials, as a reality check.

After evaluating what answers can be ascertained, a research agenda is presented to suggest lines along which future public administration enquiries might follow. Effectiveness of government and improvement of its actions has long been a rich crop to cultivate; an orderly approach to such harvests would be of value to the field. 


\section{CHAPTER II}

\section{REVIEW OF THE LITERATURE}

If God forbade drinking, would He have made wine so good? ${ }^{24}$

Interest in state entrepreneurship and public policy development in the literature has taken root in the same time frame, the decades of the 1970's and $1980^{\prime} \mathrm{s}$. Several factors interplay here as societal change took place:

-- the end of the Vietnam War, and a redirection of national, economic and academic attentions; ${ }^{25}$

-- a recession deepened by energy shortages; ${ }^{26}$

-- ever-increasing urbanization, coupled with a disenchantment with urban renewal; ${ }^{27}$

${ }^{24}$ Attributed to Armand Cardinal Richeliu; see Clifton Fadiman and Sam Aaron, The Joys of Wine (New York: Harry $N$. Abrams, 1975), p. 79.

${ }^{25}$ George E. Berkeley, The Craft of Public Administration (Boston: Allyn \& Bacon, 1978), 2nd Edition, pp. 214-215.

${ }^{26}$ Ibid. , pp. 24,341 .

${ }^{27}$ Janet Pack, "Determinants of Migration to Central Cities," Journal of Regional Science 13: August 1973, pp. 249260; James Q. Wilson (Ed.), Urban Renewal: The Record and the Controversy (Cambridge, MA: MIT Press, 1966). 
-- the shift from the "rust belt" northern industrial centers to the "sun belt" southern and western regions; ${ }^{28}$

-- a fading of the Federal initiatives for directing federally-collected money to specific social and economic issues, ${ }^{29}$ which in turn placed more pressure on states and localities to generate jobs and revenue through economic development; and

-- an alteration in America's economy from industrial production to high technology and service sectors. 30

STATE ENTREPRENEURSHIP

Prior to the 1970's, the focus of the political/tax/ public administration literature was on fiscal reasons why industries located in a given state, based upon taxes and other factors. ${ }^{31}$ Business researchers when looking at

${ }^{28} \mathrm{D}$. Perry and A. Watkins (Eds.), The Rise of the sunbelt Cities (Beverly Hills, CA: Sage, 1977); Richard McKenzie, Fugitive Industries: The Economics and Politics of Deindustrialization (San Francisco: Pacific Institute, 1984).

${ }^{29} \mathrm{U} . \mathrm{S}$. Department of Housing and Urban Development, Urban Development Action Grant Program: Annual Reports (Washington, D.C.: Government Printing office), annually from 1981.

${ }^{30} \mathrm{D}$. Gray et al. Technological Innovations: Strategies for a New Partnership (Amsterdam: North Holland, 1986); Edward Malecki, "High Technology and Local Economic Development," Journal of the American Planning Association 50: Summer 1984, pp. 262-269.

${ }^{31}$ Albert Lepawsky, State Planning and Economic Development in the South (Washington, D.C.: National Planning Association, 1949); Charles Colton, State and Local Taxes on Business (Princeton, NJ: Tax Institute of America, 1965), pp. 209-224; Benjamin Bridges, "State and Local Inducements for Industry," National Tax Journal, 18 (March and June, 1965), pp. 1-14, 
government were more interested in how government controls and regulations impacted business and industry. ${ }^{32}$

In the late 1960's and early 1970's, the spotlight began to shift. To be sure, fiscal/financial incentives were still a key focus, ${ }^{33}$ but authors began addressing the concept of government as "incubator tender," or entrepreneur. ${ }^{34}$ At the same time, states began creating administra-

175-192. See also Melvin Anshen and Francis D. Wormuth, Private Enterprise and Public Policy (New York: Macmillan, 1954); Douglass North, "Location Theory and Regional Economic Growth," The Journal of Political Economy 63: June 1955, pp. 243-258; Harry Richardson, Regional Growth Theory (London: Macmillan, 1973).

${ }^{32}$ Harold D. Koontz, Government Control of Business (Boston: Houghton Mifflin, 1941); George A. Steiner, Government's Role in Economic Life (New York: McGraw-Hill, 1953); Clair wilcox, Public Policies Toward Business (Homewood, IL: Richard D. Irwin, 1955).

${ }^{33}$ Daryl Hellman et al., State Financial Incentives to Industry (Lexington, MA: Lexington Books, 1976).

${ }^{34}$ Linda Liston, "States spar in sizzling Contest for Industry," Industrial Development and Manufacturers Board $136: 6$, 1967, pp. 22-28; Stuart Holland (Ed.), The State as Entrepreneur (London: Weidenfeld and Nicolson, 1972); Leonard Iund, Business/Government Partnership in Local Economic Development Financing (New York: Conference Board, 1976); Walter Plosila and David Allen, "Small Business Incubators and Public Policy: Implications for State and Local Development Strategies," Policy Studies Journal 13: June 1985, pp. 729-734. 
tive agencies to create jobs and attract businesses. ${ }^{35}$

Entrepreneurship journals were started in the mid1970's, focusing on the innovative spirit and business development, inspiring new approaches, reaching ever wider audiences and maturing. ${ }^{36}$

With the end of the 1970's came the election of a series of conservative Federal administrations, and an emphasis toward "privatization" of government services. States were left to their own devices to compete in the market for new industry in innovative fashions. ${ }^{37}$

What had been innovations in the 1960's and 1970's to increase citizen involvement (neighborhood councils, advisory committees, local interest groups) and revenue (ergo, state lotteries and revenue bonding) had become a

${ }^{35}$ William Thomas, Historical and Functional Aspects of State Industrial Development Organizations (Columbia, SC: University of South Carolina Press, 1975); US Congressional Budget office, The Federal Role in state Development Programs (Washington, D.C.: Government Printing Office, 1984); US Small Business Administration, state Policies and Programs to Enhance the Small Business Climate (Washington, D.C.: Government Printing Office, 1984) and The States and Small Business (Washington, D.C.: Government Printing Office, 1979).

${ }^{36}$ Specifically, the 1970 inception of Growth \& Change, Entrepreneurship: Theory \& Practice begun in 1974 and Economic Development, started in 1975.

${ }^{37}$ Michael P. Mokwa and Steven E. Permut, Government Marketing: Theory and Practice (New York: Praeger, 1981), p. xiii. 
core of entrepreneurial techniques. ${ }^{38}$ Finally, by the midand late-1980's, contributors to the literature had an opportunity to consolidate initial concepts and reflect on 25 years of state entrepreneurial activities. ${ }^{39}$

\section{RELEVANT PUBLIC POLICY IN THE NORTHWEST}

Much of the preceding material, of course, combines a specific focus on economic development with a more general focus on public policy. Other areas of public policy impact on the development of a wine industry. ${ }^{40}$

The literature provides many clues to the involvement of state and federal government agencies in these areas of public policy. It is also useful to note at this point

${ }^{38}$ Ibid.; Robert Premus, Location of High Technology Firms and Regional Economic Development (Washington, D.C.: U.S. Congress, 1982); Carol Steinbach and Robert Guskind, "High-Risk Ventures Strike Gold with State Government Financing, "National Journal 16 (September 22, 1984), pp. 1767-1771; Joseph A. Yarzebinsky, "Understanding and Encouraging the Entrepreneur," Economic Development Review $10: 1$, 1992, pp. 32-35; Zyman, op cit.

${ }^{39}$ Leonard wheat, Regional Growth and Industrial Location (Lexington, MA: Lexington Books, 1983); Eisinger, Op cit.; Roger Wilson, State Business Incentives and Economic Growth: Are they Effective? A Review of the Ijiterature (Washington, D.C.: Council of State Governments, 1989), Vol. 1 .

${ }^{40}$ General surveys of oregon public policy can be found in Iluana McCann, Oregon Policy Choices 1989 (Eugene, OR: Bureau of Governmental Research and Service, 1989) and Oregon Progress Board, Oregon Benchmarks (Salem, OR: Oregon Progress Board, 1992). Discussions of Washington public policies are available in B. Narver et al, Washington Policy Choices: 1990s (Seattle, WA: University of Washington, 1990) and other publications of that University's Institute for Policy studies. 
whether the agencies are centralized or decentralized in their activities and policy making; such aspects may provide clues to why some agencies (or states) are more effective than others in encouraging the creation of new businesses. Decentralized agencies tend to be less insular and more broadly representative of their constituencies than centralized organizations, ${ }^{41}$ although decentralization tends to discourage specialization and be more expensive. 42 Policy implementation at the local level may not be uniform across the jurisdiction, which may in turn attract new firms to (or repel them from) a specific area.

\section{Land Use}

In states where land use has become an important element, such as Oregon, ${ }^{43}$ land use laws and administrative structures favor preservation of agricultural lands for food production purposes. ${ }^{44}$ washington, on the other hand, has only recently (1990) enacted comprehensive land use laws

\footnotetext{
${ }^{41}$ Robert H. Simmons and Eugene P. Dvorin, op cit., pp. $327-330$.

42Berkeley, op cit., pp. 323-334.

${ }^{43} \mathrm{E}$. Thompson, Farming in the Shadow of Suburbia (Washington, D.C.: National Association of Counties Research Foundation, 1980); also see W. Toner, Saving Farms and Farmlands: A Community Guide (Chicago: American Society of Planning Officials, 1978).

${ }^{44}$ oregon Revised Statutes (ORS), Chapter 197, first enacted in 1973. See also Oregon Land Conservation and Development Commission (LCDC), Farm and Forest Research Study (Salem, OR: LCDC, 1991).
} 
requiring local governments to preserve a balance between urban, suburban and rural uses. ${ }^{45}$ Naturally, in either state the farmer/grower would be expected to grow whatever legal crop will bring the highest price commensurate with that grower's skills and experience.

In Oregon, the state agency charged with carrying out state policy with regard to land use is the Land and Conservation Development Department (ICDD), overseen by an appointed Land and Conservation Development Commission (LCDC). Early efforts by LCDC to limit or prohibit wineries from operating ("manufacturing") in exclusive farm-use zones were fought and turned back by individual wineries. ${ }^{46}$

In Washington, the newly enacted comprehensive land use ${ } \mathrm{aw}^{47}$ is directed by the Department of Community Development but administered by county land use planning agencies. During the period 1970-1990, Washington had no comprehensive state-wide land use planning laws.

There is no federal land use planning agency, although between 1965 and 1975 the U.S. Department of Housing and

\footnotetext{
${ }^{45}$ RCWA 36.70A, Laws 1990, 1st Extraordinary session, Chapter 17.

46"Wineries Win Land-Use Fight," Oregon Business 19:2, 1983, p. 15; John Mills, "HillCrest Vineyards: An LCDC Tale of Woe," Landmark 1:4, 1984, pp. 24-25. In 1993, Oregon's governor attempted to heal some of these historical wounds by signing into law a major revision of LCDC statutes at one of the state's largest wineries. 201.

47Ibjd; See also RCWA Chapter 35.63, Laws 1959, Chapter
} 
Urban Development played a key role in fostering planning concepts and intergovernmental planning agencies. Through the so-called "A-95" grant process, regional councils of government innovated many core land use planning programs. ${ }^{48}$

\section{Agriculture}

How crops are grown, under what conditions, and how marketed by state supported commodity agencies are a matter of public policy ${ }^{49}$ as well as historical imperative. Land which is not suitable for wheat or berries may well be ideal for grapevines. ${ }^{50}$ Together with land use law and policy, tax law, and the creation of commodity marketing commissions, the agricultural policies developed by a state can encourage (or discourage) the growing of wine grapes and the

${ }^{48}$ U.S. Congress, Housing and Urban Development Act of 1966, Title III (July 15, 1966) and Demonstration Cities and Metropolitan Development Act of 1966, Title II (August 9, 1966), 89th Congress, Second Session). See also Columbia Region Association of Governments, Columbia-Willamette Region Comprehensive Plan: Discussion Draft (Portland: The Association, 1974) and CRAG Overview: Data for the Planning Process (Portland: The Association, 1975).

${ }^{49} \mathrm{~A}$. Baliscan and $\mathrm{J}$. Roumasset, "Policy Choices of Agricultural Policy. . . " ouarterly Journal of Economics, p. 371. Crop subsidies, and controls on use of fertilizers and pesticides in certain areas, are expressions of such public policy.

${ }^{50}$ Row crops such as grains and berries are best planted and harvested on flat terrain. Grape vines do best on the south side of rolling hills, whose soil provide good drainage. 
making of wine. ${ }^{51}$

The federal Department of Agriculture (USDA) conducts some limited research into growing practices, pesticide use, and rotation practices, and provides a statistical reporting service on wineries and vineyards within the states. 52

The Oregon Department of Agriculture (ODA), working with the land-grant Oregon State University (OSU) and a subordinate Extension Service, conducts research and disseminates results on the success of various agricultural techniques. 53 The Wine Advisory Board (OWAB or WAB), whose members are appointed by the Director of ODA, is a quasicommodity commission of ODA created at the request of the wine industry to promote marketing of oregon wines. ${ }^{54}$ The state's Governor has become involved in highly visible

\footnotetext{
${ }^{51}$ At least one Oregon commercial winery exists expressly as a result of a combination of tax and land-use administrative policies.

${ }^{52}$ The USDA Agricultural Statistics Service works with state agricultural agencies and others to produce annual statistical reports.

${ }^{53}$ ORS Chapters in the 560- and 570-series.

${ }^{54}$ QRS Chapter 576. WAB promotes in-state viticultural research; ensures that oregon wines are a part of national and international agricultural trade missions, and are featured wines at social functions of state- and national-level political figures; advertises industry activities; and publishes an annual winery-location brochure.
} 
promotions in the marketing of state wines. 55

Similarly, the Washington Department of Agriculture (WDA) provides its research results to the Washington wine industry, and works with and has provided funds to the landgrant Washington State University (WSU), to develop programs impacting the growth of the wine industry. ${ }^{56}$ The seattlebased Washington wine Commission (WWC), originally underwritten by WDA, promotes the marketing of state wines. ${ }^{57}$

\section{Health}

In human beings, ethyl alcohol serves as a depressant to the central nervous system. ${ }^{58}$ under some circumstances, consumption can lead to dependency and addiction. ${ }^{59}$ Its overdose use leads to intoxication, degeneration of liver tissues, and in extreme cases death. ${ }^{60}$ Recently, some

${ }^{55}$ Each year, an international pinot noir festival is held in the heart of oregon's grape and wine territory. Both the current governor and her predecessor have made high-visibility visits and promotions of this festival.

${ }^{56}$ RCWA Chapter 43.23 .

${ }^{57}$ RCWA Chapter 15.88. WWC advertises, provides a conduit for Washington wine to Washington political figures, and irregularly publishes a guide to Washington wineries.

${ }^{58}$ Linda Hunt, Alcohol Related Problems (London: Heinemann Educational Books, 1982), p. 11 .

${ }^{59}$ Ibid., p. 12 .

${ }^{60}$ Ibjd. , p. 15-17. 
researchers are contending ${ }^{69}$ that fetuses subjected to

maternal alcohol use may be born at lower-than-average birth weights, and subject to disorders later in life.

On the other hand, alcohol in the form of wine, in

relatively small doses, has been prescribed by physicians

for centuries to relieve stress and sooth stomach

problems. ${ }^{62}$ Some evidence in modern science indicates wine

may be positively correlated with protection against

coronary heart disease, coronary artery disease, and certain

immune system disorders. ${ }^{63}$

State health agencies are concerned with the purity of

${ }^{61}$ Oregon Health Division, Reducing Risk Behaviors that Affect Health (Portland, OR: OHD, 1990); See also W.E. Strance, Alcohol Hospitality (Oregon City, OR: The Author, 1986) and OLCC's required wine tasting room label warning against maternal alcohol consumption. So-called "Fetal Alcohol syndrome," or FAS, is dismissed by others as simply a neo-prohibitionist tactic to return to a ban of all alcohol.

${ }^{62}$ Clifton Fadiman and Sam Aaron, The Joys of Wine (New York: Harry N. Abrams, Inc., 1975), p. 44. Louis Pasteur is perhaps the most famous physician to recommend wine consumption for health.

${ }^{63}$ T. Brenn, "The Troms Heart Study . . .," Journal of Epidemiology and Community Health $40: 3$ (1986), pp. 249-256; M.L. Burr, "A Tot a Day Keeps Disease Away," Proceedings of the Nutrition Society 47:2 (1988), pp. 129-133; Roland De Wolk, "Red Wines May Fight Cancer," The Wine Spectator 14 (1989), p. 7; R.G. Ferrance, "Drinking and the Prevention of Coronary Heart Disease . . . " Journal of Studies on Alcohol 47:5 (1986)， pp. 394-408; Elisabeth Holmgren's series of "Health Issues" articles in the journal Wines \& Vines; and D.R. Kaplan, "A Novel Mechanism of Immunosuppression Mediated by Ethanol," Cellular Immunology 102:1 (1986), pp. 1-9. Such reporting, and even grape-growing and wine-making by physicians is not without cost, as reported by Claudia Morain, "Grape-Growers' Wrath," American Medical News 35:24 (1992), pp. 45-49 on criticism directed at wine-making physicians. 
agricultural products. They regularly inspect for facility cleanliness, test for chemical compounds and levels proven harmful to human health, and can levy fines or require closure for failure of a facility to meet set standards. It is only in recent decades that the U.S. Surgeon General, through public relations efforts and a series of highly-publicized reports on tobacco and alcohol, has worked with state health agencies to influence the enactment of state laws regulating the consumption of tobacco and alcohol. ${ }^{64}$ success of this strategy remains in question. The relevant federal agency is the U.S. Surgeon General's office. ${ }^{65}$ Oregon's is the Health Division (OHD) of the Human Services Department. ${ }^{66}$ Washington's agency is the State Board of Health (WSBH) of the Department of Health. ${ }^{67}$

\section{Social Services}

How states and local governments collect and spend their funds for social services -- counseling, family assistance, housing, income and food assistance -- is a major element of policy debate in America. Alcohol depen-

\footnotetext{
${ }^{64} \mathrm{U} . \mathrm{S}$. Department of Health and Human Services, Healthy People 2000 (Washington, D.C.: Government Printing Office, 1990), pp. 163-184. (1944)

${ }^{65}$ United States Code (USC), Title 42, Sections 201 et seq.

${ }^{66}$ ORS Chapter 184.

${ }^{67}$ RCWA Chapter 43.20 and 43.70 .
} 
dency may be integral to other conditions which lead people to come to depend upon these services. A state's alcohol policies can support or undermine social service policy. The Oregon agency responsible for administering these policies is the Oregon Department of Human Resources (DHR), an agency with field offices scattered throughout the state $^{68}$. Washington's agency (similarly decentralized for service provision) is the Department of Social and Health Services. ${ }^{69}$ Both have subordinate Alcohol/Drug Commissions, established to provide public education on the hazards of addictive behavior and coordinate public and nonprofit services to those who become incapable of moderate use.

\section{Economic Development}

States spend money to develop industry. That money is intended to lead to state economic strength, augmented employment, expanded tax rolls, and expanded diversity of economic activity. ${ }^{70}$ The multiplier effect of creating one newly employed manufacturing person at a salary of $\$ 25,000$ may be as much as $\$ 75,000$ in secondary and tertiary jobs. ${ }^{71}$

\footnotetext{
${ }^{68}$ ORS Chapter 184.

${ }^{69}$ RCWA Chapter $43.20 \mathrm{~A}$.

${ }^{70}$ Eisinger, op cit., Chapter 3.

${ }^{71}$ This multiplier of three is estimated by the author based on interviews with wine industry sources. The multiplier effect is discussed in most modern economic textbooks. See Paul A. Samuelson, Economics, An Introductory Analysis (New York: MCGraw-Hill,1964), 6th Edition, p. 231; see also Thomas J. Hailstones, Basic Economics (Cincinnati,
} 
Oregon's relevant agency is the Economic Development Department (OEDD). ${ }^{72}$ Along with its other responsibilities, it operates welcome center/public information kiosks at each Oregon port of entry, provides tourists a variety of information, including winery brochures and events calendars, ${ }^{73}$ and administers grant and loan programs to new businesses.

A regional strategy implemented by EDD has to some extent decentralized to local, multi-county levels decision making about distribution of grant and loan funds. ${ }^{74}$

In Washington, the agency is the Department of Trade and Economic Development (WDTED). ${ }^{75}$ It also administers grant programs, but has refrained from directly supporting wine related businesses.

\section{Environmental Protection}

In concert with land use planning, what is done on the land is an important policy element in environmental protec-

$\mathrm{OH}$ : South-West Publishing Company, 1984).

${ }^{72}$ ORS Chapters 184 and 777 . Aid to wineries is made by Lottery money grants such as a $\$ 34,000$ made to willamette valley winery, guaranteed loans such as a $\$ 30,000$ loan made to Marquam Hill Vineyards, or revenue bonds ( $\$ 2$ million) used to lure Domaine Drouhain of France to locate in Oregon.

${ }^{73}$ Oregon Secretary of State, oregon Blue Book 1989-90 (Salem, OR: Secretary of State, 1989), p. 268 .

${ }^{74} \mathrm{Six}$ major regional offices of the Business Development Division, EDD in Oregon coordinate with local economic development councils to direct aid at the local level. oregon Blue Book 1987-88 (Salem, OR: Secretary of State, 1987), pp. 43-44.

${ }^{75}$ RCWA Chapter 43.31 . 
tion. An industry which pollutes air, land or water is deemed undesirable absent mitigating measures to minimize environmental consequences. On the other hand, a seemingly non-polluting farming industry is deemed highly desirable. ${ }^{76}$

As an agricultural use, wine grape growing is generally benign; the vines produce no toxic byproducts, and generally few pesticides or bird-repellant sprays are used to impact land or ground water, negatively affecting sales. Fertilizers are used, but do not include the types (manure) that typically cause runoff pollution. However, acetic acids drawn off from wine production processes, or wine which is deemed not commercially acceptable to the wine maker, can cause disposal problems."

In Oregon, the appropriate agency is the Department of Environmental Quality (DEQ) $i^{78}$ Washington's is the Department of Ecology. ${ }^{79}$ Both states' agencies are authorized to levy fines to enforce state laws and rules, and are centralized in their decision and policy making processes.

\footnotetext{
${ }^{76}$ Industries associated with clearly-defined contributions to the local environment's pollution load are called "point sources," while grape-growing and wine making may make small and incremental contributions -- "non-point" sources.

77 Because of terrain and drainage issues, acid- or wine"dumping" can impact the groundwater downstream from the winery. Environmental Quality regulations usually require some analysis by the winery of where groundwater goes once it leaves the vineyard or winery area.

${ }^{78} \mathrm{ORS}$ Chapter 468.

${ }^{79}$ RCWA Chapter $43.21 \mathrm{~A}$.
} 
The federal Environmental Protection Agency (EPA) has no records of involving itself in the wine making industry.

\section{Einance, Revenue, and Taxation}

A new, growing industry ${ }^{80}$ will need nurturing and testing in the marketplace, and will also bring in revenues to state and local government. This in turn impacts government finance, as problems arise that engender regulation or that policy makers determine need state supported finances. Finally, the agencies that see to the setting of tax policy, and the collection thereof, will also become involved.

In Oregon, three principal state agencies collect revenues and taxes from the wine industry: the Department of Revenue (ODOR), ${ }^{81}$ the Oregon Liquor Control Commission (OLCC), 82 and the Wine Advisory Board (WAB or OWAB). ${ }^{83}$ Washington has the same three agencies; the Department of Revenue (WDR), ${ }^{84}$ the Liquor Control Board (WLCB), ${ }^{85}$ and the

${ }^{80}$ It need not be wine; in Oregon and Washington, emerging new industries are being created around computers, microbreweries, and custom nurseries which might serve equally well as models.

${ }^{81}$ ORS Chapter 305.

${ }^{82}$ ORS Chapters 471-473.

${ }^{83}$ ORS Chapter 576. Moneys are collected by the Department of Revenue and surrendered to the Board.

${ }^{84}$ RCWA Chapters 43.17 and 82.01 .

${ }^{85}$ RCWA Chapter 66.08 . 
Wine Commission (WWC).${ }^{86}$ OLCC and WLCB are authorized to levy fines for infractions of the law and their rules.

Labor

A secondary issue which impacts almost all farm/ agricultural enterprise is how the crops are picked. California vineyards, which often are hundreds of acres in size, utilize a planting/trellising strategy which encourages the use of machinery to remove the grapes for processing. This minimizes their need for unskilled labor. Vineyards in the Northwest tend to be much smaller, with an average total size in 1991 of about 18 acres, ${ }^{87}$ of which about 10 acres were harvested. ${ }^{88}$ Like "stoop labor" crops, Northwest wine grapes are often picked by migrants. Watching over the laborers' rights (wages, working conditions, living conditions) in oregon is the Bureau of Labor. ${ }^{89}$ Washington's labor "watchdog" is the Department of Labor and Industries. ${ }^{90}$ Both are authorized to levy fines to enforce state statutes and administrative rules.

${ }^{86} \mathrm{RCWA}$ Chapter 15.88 .

${ }^{87}$ USDA Statistics Service, 1991 Oregon Vineyard Report (Portland, OR: USDA, 1992), p. 2. Oregon had 350 commercial vineyards, totalling 6,050 acres with 3,700 being harvested.

${ }^{88}$ This is the same average producing-vineyard size found in France; Loubere, op cit., chapters 1-2.

${ }^{89}$ ORS Chapters in the 660-series.

${ }^{90}{ }_{\text {RCWA }}$ Chapters 43.17 and 43.22 . 
Such watchdogs do not, of course, prevent labor problems from growing into labor disputes. However, the history of labor unrest among Northwest wineries is brief. ${ }^{91}$ Inspectors range throughout both states, while policy making is centralized in their respective state capitals.

\section{Law Enforcement}

Two sets of laws are of note here: the liquor laws, which detail who may sell alcoholic beverages to whom, where, when and under what circumstances; and the general good-of-the-order criminal laws which govern social conduct (public drunkenness, assaults, driving under the influence).

Oregon's OLCC interprets and administers the liquor laws, while social conduct laws are enforced by the Oregon State Police (OSP) 92 and local agencies. Washington's liquor laws come under the WLCB, while state enforced general laws come under the Washington State Patrol (WSP) ${ }^{93}$ and city and county police. ${ }^{94}$

91 "Chateau Ste. Michelle Workers Urge National Boycott of Winery," The Oregonian (September 8, 1992), p. C7.

${ }^{92}$ ORS Chapter 181.

${ }^{93} \mathrm{RCWA}$ Chapter 43.43 .

${ }^{94} \mathrm{As}$ an interesting side note, a 1989 local-level county jury in Everett, Washington determined that a wine bottle can be viewed as a "deadly weapon," after a convenience store robber hit a store clerk over the head with one during his escape attempt. The blow added two years to the robber's sentence. See "'Deadly Weapon' Cited," The Oregonian, November 3, 1989, p. B4. 
The primary load for enforcing state statutes in both Oregon and Washington relating to public drunkenness and other liquor offenses falls on city and county authorities.

\section{Transportation}

In addition to providing a key part of the infrastructure necessary to bring products to market, an important element to many wineries is the ability to draw tourists and casual travelers to their doorstep. Each state has tourist center and winery-signage programs to do just that, to encourage tourist expenditures throughout their areas.

Oregon's Department of Transportation includes a subordinate Travel Information Council, which establishes and operates a centralized policy on Tourist-Oriented Directional signage, including those for wineries. 95 Tourist centers at all ports of entry into the state, owned by the Highway Division but operated by the OEDD's Tourism Division, provide first point-of-contact information for out-of-state drivers seeking winery data.

On the other hand, Washington's Department of Transportation is decentralized into its several districts. It also operates several port-of-entry kiosks, providing tourist information on wineries and wine events. Its touristsignage programs are conducted at the option of the regional

\footnotetext{
${ }^{95}$ Oregon Secretary of State, Oregon Blue Book 1989-1990
} (Salem, OR: Secretary of State, 1989), p. 127. 
manager, and some have chosen not to provide winery-signage programs within their areas of administration. ${ }^{96}$

Table III summarizes the similarities and differences of centralized and decentralized policy making and program execution involvement of state administrative agencies responsible for wineries.

TABLE III

STATE ADMINISTRATIVE AGENCY

FUNCTIONAL AREA CENTRALIZATION/DECENTRALIZATION, 1970-1990

\begin{tabular}{|c|c|c|c|c|}
\hline \multirow[b]{2}{*}{ rea } & \multicolumn{2}{|c|}{ Oregon } & \multicolumn{2}{|c|}{ Washington } \\
\hline & Policy & Program & Policy & Program \\
\hline $\begin{array}{l}\text { Land Use } \\
\text { Agriculture } \\
\text { Research/Educ. } \\
\text { Health } \\
\text { Social Services } \\
\text { Economic }\end{array}$ & $\begin{array}{l}\text { Central. } \\
\text { Central. } \\
\text { Central. } \\
\text { Central. } \\
\text { Central. }\end{array}$ & $\begin{array}{l}\text { Decent. } \\
\text { Decent. } \\
\text { Decent. } \\
\text { Decent. } \\
\text { Decent. }\end{array}$ & $\begin{array}{l}\text { N/A } \\
\text { Central. } \\
\text { Central. } \\
\text { Central. } \\
\text { Central. }\end{array}$ & $\begin{array}{l}\mathrm{N} / \mathrm{A} \\
\text { Decent. } \\
\text { Decent. } \\
\text { Decent. } \\
\text { Decent. }\end{array}$ \\
\hline Development & Central. & $\begin{array}{l}\text { Central./ } \\
\text { Decent. }\end{array}$ & $N / A$ & $N / A$ \\
\hline $\begin{array}{l}\text { Environmental } \\
\text { Protection } \\
\text { Finance/Revenue } \\
\text { Labor } \\
\text { Liquor Control } \\
\text { Policing } \\
\text { Tourism } \\
\text { Signage } \\
\text { Marketing } \\
\text { Assistance }\end{array}$ & $\begin{array}{l}\text { Central. } \\
\text { Central. } \\
\text { Central. } \\
\text { Central. } \\
\text { Central. } \\
\text { Central. } \\
\text { Central. }\end{array}$ & $\begin{array}{l}\text { Decent. } \\
\text { Central. } \\
\text { Decent. } \\
\text { Decent. } \\
\text { Decent. } \\
\text { Central. } \\
\text { Central. }\end{array}$ & $\begin{array}{l}\text { Central. } \\
\text { Central. } \\
\text { Central. } \\
\text { Central. } \\
\text { Central. } \\
\text { Decent. } \\
\text { Decent. }\end{array}$ & $\begin{array}{l}\text { Decent. } \\
\text { Central. } \\
\text { Decent. } \\
\text { Decent. } \\
\text { Decent. } \\
\text { Decent. } \\
\text { Decent. }\end{array}$ \\
\hline
\end{tabular}

Table III illustrates that, between 1970 and 1990 , the bulk of Oregon and Washington agencies with similar respon-

${ }^{96}$ Richard and Charity Yates, 1992 washington State Yearbook (Seattle, WA: Information press, 1992), p. 79. The signage program information was gathered from several interviews of Washington winemakers, and survey returns. 
ibilities were organized and empowered as to centralized versus decentralized policy and program activities.

However, Oregon had in place laws, policies and programs at the state level to control land use and provide economic development assistance to wineries. In addition, policy making in the areas of tourist information and road signage relating to wineries was under centralized control in Oregon, but under decentralized control in Washington.

\section{WINE AND ITS IMPACTS}

Wine and wine making have been with mankind for perhaps over 100,000 years, although of course written history limits our knowledge to a mere 5,000 years. ${ }^{97}$ Most texts are broad in historical scope, focused on Europe, and tied to discussions of specific wines and their production. ${ }^{98}$

Throughout this history, wine has served not only social functions, but has been central to some religious ceremonies $^{99}$ and civil affairs, ${ }^{100}$ has been a key component in

${ }^{97} \mathrm{~J}$. Elizabeth Purser and Lawrence J. Allen, The Winemakers of the Pacific Northwest (Vashon Island, WA: Harbor House, 1977), p. 9 .

${ }^{98}$ Artlott, op cit.; Asher, op cit.; Fadiman and Aaron, op cit.; A.D. Francis, The Wine Trade (London: Adam and Charles Black, 1972); Hugh Johnson, The World Atlas of Wine (New York: Simon \& Schuster, 1977).

${ }^{99}$ Christianity utilizes wine as a sacrament, and wine serves as a blessing and celebration of life in Jewish ceremonies as well. Odelia E. Alroy, "Kosher Wine," Judaism: Quarterly Journal 39:4 (Fall 1990), pp. 452-460. 
some national economies, ${ }^{101}$ and has provided a safe substitute for polluted water. ${ }^{102}$

Wine has also served as a rallying point for national pride. Some national governments take this last point more seriously than others, putting to death those who would fraudulently misrepresent the national drink. ${ }^{103}$

One key to the posed problem is America's perception of wine as an alcoholic beverage, rather than a food. As an alcoholic beverage, wine is grouped together with beer and hard liquor, both in its use and its impacts. Other nations and cultures consider wine to be food, a complex set of hydrocarbons whose 200-plus components interact with food in a manner no simple ethanol drink can match. ${ }^{104}$

\section{OREGON WINE HISTORY}

Oregon's wine history is perhaps less well documented than Washington's. One of the most comprehensive recent

${ }^{100}$ purser, op cit., p. 10 .

${ }^{101}$ Leo A. Loubere, The wine Revolution in France (Princeton, NJ: Princeton University Press, 1990).

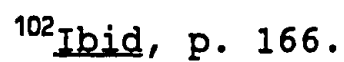

${ }^{103}$ In early 1993, the People's Republic of China executed Luo Deming for misrepresenting ordinary white table wine as "maotai," a prestige liquor distilled from sorghum. See "Menus \& Venues: Shoddy Spirits Bring Death Sentence," The Oregonian (March 10, 1993), p. D6.

${ }^{104}$ Cardiologist Dr. R. Curtis Ellison, in a speech before the "Women for Winesense" group, Portland, Oregon, February $17,1993$. 
texts, by Corbet Clark, ${ }^{105}$ addresses Oregon's general wine history as well as a brief note on each winery cited. ${ }^{106}$

Spreading outward from Fort Vancouver and the Hudson's Bay employees, grapes were grown in the willamette Valley in the mid-1800's. ${ }^{107}$ As early as 1835 , Oregonians had set up a still to convert wine into brandy. ${ }^{108}$

By the late $1800^{\prime} \mathrm{s}$, Oregon had several wineries located west of Portland and in Southern Oregon, most of which were probably farm wineries (farms whose principal business would have been with other products and crops). ${ }^{109}$ There was also a growing wine industry in the Roseburg area. ${ }^{110}$

This small industry produced mainly for local consumption, and was essentially eliminated by Prohibition. ${ }^{111} \mathrm{~A}$ brief resurgence in the $1930^{\prime}$ s failed in the face of stiff competition from California's rising tide of wineries. ${ }^{112}$ Winemakers from the University of California at Davis' wine making program began making their way north into Oregon

${ }^{105}$ Clark, Op cit., pp. 45-48.

${ }^{106}$ Ibid, pp. 139-241.

${ }^{107}$ Ibjd, p. 45; see also Purser, op cit., p. 153.

${ }^{108}$ Purser, op cit., p. 154 .

${ }^{109}$ Ibjd, p. 45.

${ }^{110}$ Purser, Op cit., p. 154 .

${ }^{111}$ Ibid., pp. 45-46.

${ }^{112}$ Ibid. , p. 46 . 
in the $1960^{\prime} \mathrm{s}^{113}$ Searching for places to duplicate the growing conditions of Burgundy and Bordeaux, in which to recreate the classic red wines of France, these newcomers rediscovered the vineyards of Oregon. ${ }^{114}$

In 1968 the Economic Development Division of the Commerce Department (prior to being split off as a separate department) sent Governor Tom McCall a memo on Oregon wine. The subsequent analysis showed that a wine grape industry might show "dramatic economic potential" for the state. 115

Table IV depicts winery numbers in Oregon since 1970.

TABLE IV

WINERIES IN OREGON, 1970-1993*

Beginning of:

1970

1975

1980

1985

1990

1993
Number of wineries

3

11

22

40

83

97

* Commercial wineries in operation and in production. ${ }^{116}$

${ }^{113}$ Ibid. , pp. 154-155.

${ }^{114}$ Clark, op cit., pp. $46+$.

${ }^{115}$ John F. Potticary, Potential for the Development of a Wine and Supporting wine Grape Industry in Oregon (Salem, OR: Oregon State Department of Commerce, Economic Development Division, August 1968).

${ }^{116}$ Drawn from a variety of sources: Oregon wine Press, Oregon Wine Advisory Board, Oregon Liquor Control Commission year-end reports, Oregon Winegrowers' Association 1991 Membership Directory (Portland: Winegrowers' Association, 1991) and their annual Discover oregon wineries brochures. Each reports a different number, variously not taking into 
These numbers are net, omitting those commercial wineries that during the course of 1970-1990 ceased operation.

\section{WASHINGTON WINE HISTORY}

Perhaps the first known vineyard in Washington was started at Fort Vancouver in 1825 , by employees of the Hudson's Bay Company (although they may have been preceded a decade earlier by French-Canadian fur traders). ${ }^{117}$ wine making at this time is inferred only, in that available evidence is only indirect.

Wine was known to have been shipped to Fort Vancouver by merchants; glass wine bottles and corks were manifested from London. The vineyards thus being serviced have long since disappeared. ${ }^{118}$

Between 1870 and 1920 , more grape growing and wine experimentation took place in washington. With the opening of the Walla Walla Valley to settlement in the 1860 's, vineyards were planted and wine made by over two dozen growers. This boom continued until the $1880^{\prime} \mathrm{s}$, when market competition from California, a shortage of water, and Walla Walla's isolation from transportation and major metropolitan

account wineries not yet in commercial operation; wineries with suspended operations; wineries in bankruptcy; and so on.

${ }^{117}$ Ron Irvin, "Planting Dreams: Washington State's Wine Roots," The Northwest Palate 6:6 (January/February 1993), p. 26 .

${ }^{118}$ Ibid., p. 26. 
areas contrived to close the commercial wineries. ${ }^{119}$

In 1871 and 1872 , commercial and personal vineyards were developed in the Yakima Valley and Puget Sound areas. By 1900, creation of irrigation companies and development of the railroads opened land for vineyard formation. ${ }^{120}$

Wineries were started in the Kennewick and Yakima Valleys, where they produced limited vintages until state initiated prohibition laws were enacted in 1916, followed in 1920 by the 18th Amendment to the U.S. Constitution. ${ }^{121}$

After Prohibition's repeal in 1933, several wineries were started in the Seattle and eastern Yakima Valley areas. Legislation was enacted by the washington legislature ${ }^{122}$ to prevent the newly-reviving industry from being suppressed by predatory market practices (selling wine at less-than-cost prices) from wineries located outside Washington's borders. Despite the Depression of the 1930 's, by 1938 there were 42 wineries in Washington, all new and serving wash-

${ }^{119}$ Clark, op cit., p. 40; Purser and Allen, op cit., p. 66; Irvine, op cit., pp. 26-27, 29.

${ }^{120}$ Irvine, op sit., p. 27.

${ }^{121}$ Ibid. , pp. 27, 29.

${ }^{122}$ Clark, op cit., pp. 40-41. See chapter 62, Laws, Extraordinary Session 1933 (Olympia, WA: Washington Legislature), which repealed Prohibition in Washington, created the Liquor Control Board, required all wineries to make sales only to the Board, distinguished between domestic and out-of-state wineries, and levied fees. Out-of-state wineries, if they wanted to sell in Washington, were required to pay the same fee as domestic wineries, even if they paid similar fees in their own states. 
ington's pent-up demand for alcoholic beverages. The wines were "American style," sweet and not complex, made from apples, berries and local grapes. The taste for Europeanstyle wines, dry and complex, had not yet been developed. ${ }^{123}$ World War II put half of Washington's wineries out of business, diverting materials needed for war use - sugar, tires, and chemicals. Manpower for picking and processing was also restricted. By 1948 , the number was down to $20 .{ }^{124}$ Post-war Washington's population boomed, and the demand for wine from a young, mobile population grew dramatically. The Washington Liquor Control Board, seeking to meet the growing public demand for wine, dramatically increased imports from out of state. As the state's largest distributor of wines, and the industry's principal regulator, it also became the domestic industry's principal competitor. ${ }^{125}$ In the 1950's, the washington industry which was producing premium, higher-priced wine stagnated and drifted, as competition from external sources importing lower-cost products commanded the market place. By 1954, two pre-war wineries - National Wine Company and Pommerelle - merged to become American wine Growers, which came to dominate the

${ }^{123}$ Ron Irvine, "Planting Dreams: Washington State's Wine Roots, Part II," The Northwest Palate 7:1 (March/April 1993), pp. 38-39 (hereafter "Planting Dreams II").

${ }^{124}$ Ibid. , p. 39.

${ }^{125}$ Ibid., p. 39. Only a half dozen private wine distributors operate within the state. 
Washington market in later years. ${ }^{126}$

A wine research center begun at Prosser in 1937 became the focus for development of European-style wines. In 1964, the Washington wine and Grape Growers' Council, an industry group, funded a 10 -year effort $(\$ 1,250$ in the first year) called the Washington wine Project to study vinifera grape culture applications. This study parallelled the beginning of viticultural research at Washington State University, which used cuttings from the Prosser research station. ${ }^{127}$

In spite of these efforts, the number of Washington wineries fell to 10 by 1969 . In that year, the washington legislature repealed restrictive marketing laws and opened the local markets to full competition by the Californians. ${ }^{128}$ By 1970, only three commercial wineries remained, one of which was American Wine Growers, now under the label of "Ste. Michelle." Associated Vintners, a collection of university employees excited by the results of their

${ }^{126}$ Clark, op cit., p. 42.

${ }^{127}$ Irvine, "Planting Dreams II," The Northwest Palate 7:1 March/April 1993), p. 39. See also Purser, Op cit., p. 67 for a more detailed description of research efforts in Washington wine grapes.

${ }^{128}$ Irvine, "Planting Dreams II," p. 38. Chapter 21, Washington Laws, 1 t Extraordinary Session (Olympia, WA: Washington Legislature, 1969) changed import licensing and taxes to be equivalent for both domestic and imported wines, and permitted wineries both to establish tasting rooms and to import out-of-state grapes and juice for wine production. 
research, was one of the others. ${ }^{129}$ Several thousand acres of vineyards were still producing wine grapes, waiting for wine makers searching for new opportunities.

Table $\mathrm{V}$ illustrates the rate of winery development in Washington since 1970. Once again, the numbers are net figures, reflecting the loss of commercial wineries to merger, bankruptcy, or closure for other reasons.

TABLE V

WINERIES IN WASHINGTON, 1970-1993*

Beginning of:

1970

1975

1980

1985

1990

1993
Number of wineries

3
3
20
61
83
85

3

61

83

*Commercial wineries in operation and in production. ${ }^{130}$

Washington's wine industry is a dichotomy, dominated by a few very large wineries but bolstered by the over 50 small firms created during its 1975-1985 growth spurt concurrent with the back-to-the-land movement of young urban professionals. Together with the premium-wine profit motive, the romance of being a winery owner and rediscovered wine making

${ }^{129}$ Ibid., p. 39 ; see also Purser, op cit., p. 68.

${ }^{130}$ Again, the number varies by which agency is reporting. See Washington Wine Commission, Touring the Washington wine Country (Seattle: The Commission, 1988). The WLCB reports a different number in its monthly reports. 
"roots" motivated many to enter the business, especially in the arid Tri-Cities area.

Federal irrigation policies may have had a greater impact than state policies and available state resources for assistance on this pattern of growth. Not until the industry began financing research and marketing efforts through self-imposed fees did the state government (through Washington State University and the wine Commission) visibly become involved in the wine industry's growth.

On the other hand, Oregon winery numbers began to grow when indigenous farmers and families took up growing wine grapes as a natural progression toward a higher-value crop, or as a hobby - none of the wineries exceed 100,000 gallons of annual production capacity. Former assistant wine makers from California also sought their own professional identities in the Burgundy-like willamette valley climate. Oregon's growth in wineries has been steady, with a more rapid expansion in the late $1980^{\prime} \mathrm{s}$ as state policies relating to land use, environment, taxes, and economic development have come into play. As with washington, much of Oregon's research and marketing policy is financed by the industry's self-assessment on harvested grape tonnage and wine sales. 
CHAPTER III

\title{
CONTEXT
}

\begin{abstract}
But, thanks to wine-lees and democracy, We've still our stage where truth calls spade a spade! ${ }^{13}$
\end{abstract}

Context is a necessary element in understanding the courses of action public administrators take when addressing a problem, issue, or policy. "Politics," "public administration," "public philosophy" and "public policy" are shorthand terms often intermingled and confused with one another. Some clarification for the purposes of this discussion are in order.

\section{DEFINITIONS}

As used herein, "politics" or political action is a process for the exercise of power and the making of compromises, in either a public or private arena, for the allocation and use of resources. ${ }^{132}$ "Public administration"

${ }^{131}$ Robert Browning, Aristophanes' Apology, at 392.

${ }^{132}$ There is no fixed definition of this term, in that it changes with time, contemporary values, and historical events. From the Greek, "politika," one primary definition from the 1960 's is "the art or science concerned with the guiding or influencing of governmental policy." Webster's Seventh New Collegiate Dictionary (Springfield, MA: G.\&C. Merriam, 1967), p. 657 . 
is the process by which people, employed by a governmental entity, jointly work toward common goals. ${ }^{133}$

"Public philosophy," which in some sense underpins all stable political entities is:

[T]he "political formula" - the "legal and moral basis, or principle, on which the power of the political class rests." It is something that can and does change over generations. Some types of public philosophy may be better, in various ways, than others. And it is possible to discover what the prevailing public philosophy is and to assess its significance by straightforward interpretation of the policies of government ${ }_{134}$ and their impact, real or threatened, on society.

Finally, "public policy" is a course of practices, actions, procedures and tactics developed within a public philosophy to guide decision making in the governmental realm. ${ }^{135}$ A variety of actors can determine public policy, a concept which needs further explanation.

PUBLIC POLICY

Who develops public policy? When stated at the beginning of a public law, "It is the policy of the state of - .," clearly the Legislature is speaking. However, in a

${ }^{133}$ Berkeley, op cit., pp. 2-3.

${ }^{134}$ Theodore Lowi, "The Public Philosophy: Interest-Group Iiberalism" in Edward V. Schneier (Ed.), Policy-Making in American Government (New York: Basic Books, 1969), p. 321.

${ }^{135}$ There is no single definition in the literature agreed upon by all authors and researchers. See, for example, Simmons and Dvorin, op cit., pp. 395-434; Schneier, op cit., pp. 3-48; George Berkeley, op cit., pp. 494-495. 
representative form of government it is also the voters who elected those legislators who are speaking.

If a policy is contrary to the voters' desires, it is within their power to replace the legislators with others who will "do the voters' bidding," or else bypass them. This power was utilized in the repeal of Prohibition.

Special interest groups at local, state and federal levels take (often the lead) part in policy formation. A special interest --lone organizations, associations, or groupings of individuals -- feel or have found that individual action is not as effective as group action. Through lobbying of legislators, support of candidates, and service on technical advisory committees, these interests' positions become well known to both law-makers and administrators. ${ }^{136}$ Public administrators make and shape public policy, in several ways. Public employee unions serve as special interest groups, as noted above. The administrative rule process carries out legislation, and those rules express administrative officials' wishes and desires. ${ }^{137}$ Budget development and implementation is used as a tool of policy making by public administrators. At all government levels,

${ }^{136}$ Keith E. Hamm, "Patterns of Influence among Committees, Agencies, and Interest Groups," Legislative Studies Quarterly, $8: 8$ (1983), pp. 379-426; Jeffrey M. Berry, The Interest Group Society (Glenview, IL: Scott, Foresman, 1989).

${ }^{137}$ Robert L. Rabin, Perspectives on the Administrative Process (Boston, MA: Little, Brown and Company, 1979), pp. 265-287. 
preliminary budgets are prepared by administrative agencies. If a proposed budget omits or deemphasizes a program, the policies embedded in that program can be suppressed.

If at a later time budget cuts are required to balance a budget, recommended cuts in spending or personnel may be aimed at unpopular or outmoded policies. Similarly, policies supported by public administrators will have adequate funding recommended. ${ }^{138}$

Finally, it is up to those in public service to enforce and implement laws and administrative rules. If an administrator decides an overly stringent or poorly written law may damage or destroy an industry, a philosophy of "benign neglect"139 may be adopted in enforcement practices. on the other hand, a policy may be enforced zealously if the administrator(s) in charge agree that, either consciously or unconsciously, that particular policy is best for the "public good." 140

${ }^{138}$ Aaron Wildavsky, The Politics of the Budgetary Process (Boston, MA: Little, Brown and Company, 1974), especially chapters 1 and 2 .

${ }^{139}$ While respecting some interviewee's request for privacy, this is the policy perceived by the industry attributed to the Oregon Liquor Control Commission from 1970 through about 1985. With the rise of the so-called NeoProhibitionists, the OLCC has taken a more active role in regulating wineries. For example, every tasting-room employee and volunteer must take and pass the same licensing examination required of bartenders and cocktail servers.

${ }^{140}$ This would seem to be the attitude of the US Bureau of Alcohol, Tobacco and Firearms agency. While some winemakers have reported some very positive experiences, BATF label reviews are subjective and has adopted an agency policy of 
PUBLIC POLICY CLUSTERS

While the academic study of public policy tends to focus narrowly on individual policies, rarely does any one policy operate in a vacuum. Not only do the players legislators, individual voters, special interests, and public administrators - influence and make public policy, but other policies in part impact the outcome of how policies are developed and enforced. ${ }^{141}$

It is within this framework that the analysis in this study is conducted. For each policy, Figure 1 may apply.

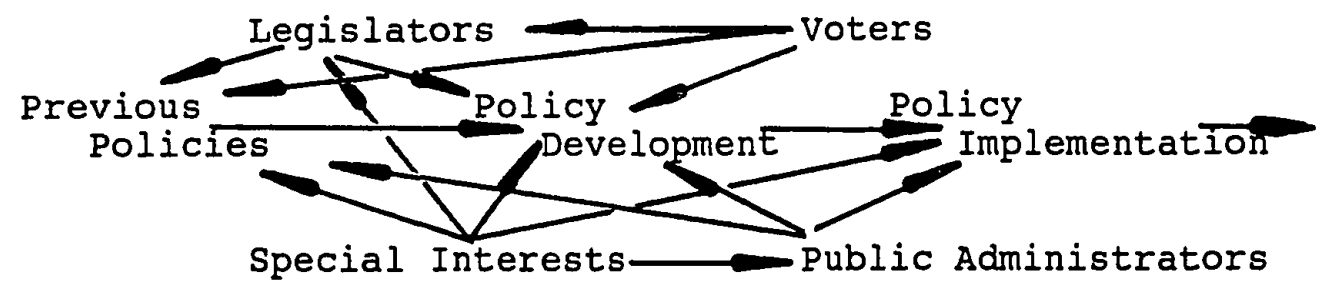

Figure 1. Policy Development.

However, as laws and policies are developed and interpreted for one area, other policies impact upon that

taking legal action against any winery which proclaims any health benefits of wine consumption. This policy is contained not in statute or administrative rule, but rather in letter.

${ }^{141}$ This concept has been addressed in so-called "iron triangle" patterns, wherein legislators, administrators and interest groups are said to control how (especially) national policy is made. Focus and attention has also been upon "power clusters," which introduces the concept of multiple agency involvement at the national level in strategic areas such as national defense, urban affairs, transportation, law enforcement, and so on. See Daniel M. Ogden, How National Policy is Made (Portland, OR: The Author, 1989). 
process. In the case at hand, the states' general policies as they relate to land use, agriculture, health, social services, economic development, environment, finance, labor, and law enforcement impact upon what a state does to develop or hinder development of an industry such as wine making, as shown in Figure 2 .

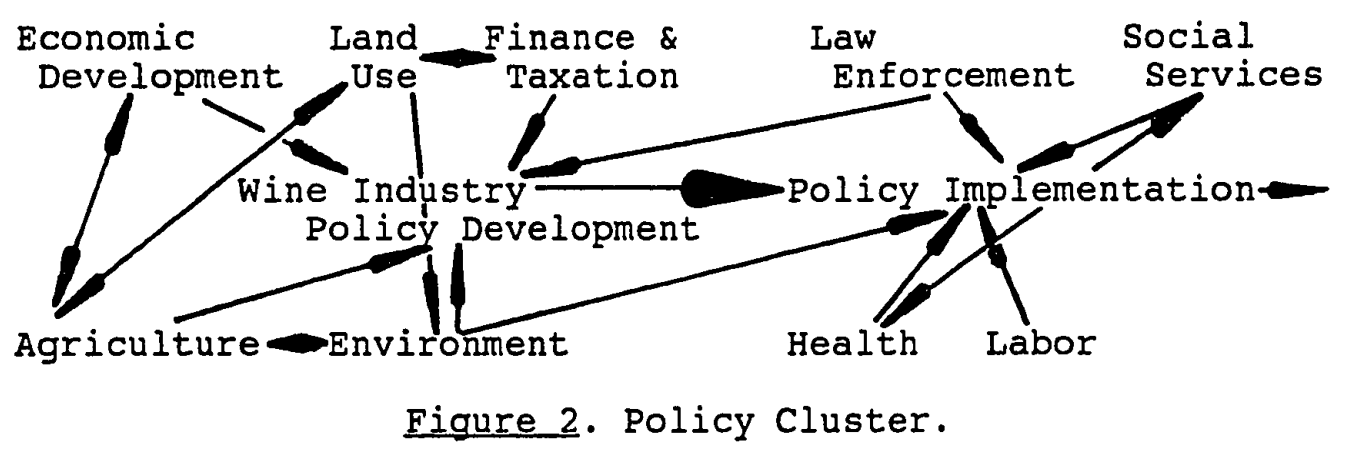

In other words, some of a state's policies on economic development, land use, finance and taxation, agriculture, liquor law enforcement, and environmental concerns help shape a wine industry policy development in its formative stages. Environmental, social services, health, labor, and law enforcement considerations help shape its implementation. ${ }^{142}$

\section{CULTURAL COMPARISONS}

The original settlers of Oregon were farmers, religious

${ }^{142}$ This practice is now being introduced at practical levels within Oregon state government. The first multi-agency coordinating group was formed in 1993 to address growth management policy. Barbara Roberts, Speech before the West Linn Chamber of Commerce, West Linn, OR, April 27, 1993. 
groups and families - Protestants, and often missionaries. Their value systems were distinctly Christian and moralistic, carryovers from their work-ethic-bound central and Western European ancestors and their own recent backgrounds from puritanical New England, and later in the $1840^{\prime} \mathrm{s}$ economically depressed "Bible Belt" areas of the Mississippi, Missouri, and Ohio river valleys. ${ }^{143}$

On the other hand, while some of these immigrants also made their way into what is now Washington, many of the earliest Washingtonians were single males of Scandinavian and German extraction by way of the Wisconsin-MichiganMinnesota region. They were attracted to the opportunities of trapping, logging and fishing at the frontier of the U.S., and brought with them value systems perhaps not as tied to religion as their Oregon neighbors. ${ }^{144}$

These immigrants were also more than willing to intermarry into Indian populations, which led others to develop a "market" for imported Eastern brides ("Mercer girls"). Later waves of immigrants stopped off on their way to the Alaskan gold fields, and brought with them an entrepreneurial spirit

${ }^{143}$ Oregon Blue Book 1987-88 (Salem, OR: Secretary of State, 1987), pp. 430-434.

${ }^{144} \mathrm{Nice}$, David $\mathrm{C}$. et al. Government and Politics in the Evergreen State (Pullman, WA: Washington State University, 1992), p. 1. Washington has one of the lowest religious affiliation rates in the U.S. 
that remains to the present day. ${ }^{145}$

Generally speaking, washington is a more cosmopolitan state than is Oregon. On two-thirds of the land area of Oregon, washington's population is: of a density two and a half times greater; faster growing ( 17.88 versus 7.98 for Oregon, 1980 to 1990); younger by more than a year at the median ( 33.2 versus 34.5 ); better educated; somewhat more racially diverse ( 118 versus Oregon's 78 minority population, although Oregon has a larger Hispanic population); and wealthier with a per capita income 108 higher than oregon. ${ }^{146}$ At the same time, Oregon receives 108 more federal aid per capita; has about 408 more local governments per capita; employs 108 more full-time-equivalent state workers per capita; experiences (in recent years) about 908 of the crime rate per 100,000 residents; and consumes on a per capita basis only 808 of the energy that washington does. ${ }^{147}$

Both states are divided geographically into one-third coast and rain forest, and two-thirds high plateau desert by

${ }^{145}$ Harold E. Barto and Catherine Bullard, History of the State of Washington (Boston: D.C. Heath, 1953), pp. 152-155.

${ }^{146}$ The bulk of this data is drawn from the us Census Bureau's Population of Census 1990 (Washington, D.C.: US Census Bureau, 1992) and County and City Data Book 1988 (Washington, D.C.: US Census Bureau, 1989).

${ }^{147}$ U.S. Department of Commerce, Bureau of the Census, Statistical Abstract of the United States 1992 (Washington, D.C.: U.S. Government Printing Office, 1992) and State and Metropolitan Area Data Book 1991 (Washington, D.C.: U.S. Government Printing Office, 1991). 
the Cascade Mountains, with most of the population of each in the northern part of the western one-third. This can on occasion result in east-west splits of opinion on social and political matters. Seattle's location on Puget Sound makes it a major West Coast and Pacific Rim seaport and transportation center, while Portland at some 60 miles inland and less oriented to container shipping is a secondary port. Similar proportions of the populations of Washington and Oregon are distributed in employment sectors: farm (38\%$398)$, manufacturing (138-148), wholesale (48), retail (128$138)$, services $(88-98)$, and government (108), with the balance in fishing, lumber, and other natural resources. ${ }^{148}$

\section{POLITICAL COMPARISONS}

Politically, Washington's population tends in recent decades to vote independently and with split tickets. Political party organizations have been steadily weakening in the twentieth century. ${ }^{149}$

Oregonians have tended in the last 30 years not to pay much attention to political party, although voter registration favors the Democratic Party. About equal numbers of Democrats and Republicans have gone to federal offices and

${ }^{148}$ U.S. Department of Commerce, Bureau of the Census, County and City Data Book 1988 (Washington, D.C.: U.S. Government Printing Office, 1989).

${ }^{149} \mathrm{Nice}$ et al., op cit., pp. 1-2. 
the Governor's office, but overall voters have preferred Democratic majorities in the Legislative Assembly. ${ }^{150}$

Lobbying on behalf of the wine industry in washington is multi-faceted. The director of the washington wine Commission (government) is also director of the Washington wine Institute (industry), and provides testimony in the latter role before legislative and administrative committees. In addition, a "government affairs liaison" based in olympia, monitors and tracks day-to-day issues for the Institute and warns of upcoming concerns. Ste. Michelle's Director of Marketing (also currently an Institute board member) provides lobbying support for that firm, and can draw on the governmental affairs suborganization of the parent U.S. Tobacco corporation. On occasion, individual winery owners interact with legislative and state agency personnel to further the interests of both themselves and the industry. ${ }^{151}$

In Oregon, winery interests are monitored and testimony provided by the director of the Oregon Winegrowers' Association, which shares offices with, but is separate from, the state's Wine Advisory Board. ${ }^{152}$ That director provides

${ }^{150}$ Oregon Blue Book, pp. 364-390.

${ }^{151}$ Interviews with washington wine Commission/Institute staff, 1991-1993.

${ }^{152}$ Interviews with Oregon Winegrowers' Association staff, 1992-1993. 
liaison with both legislators and administrators.

California wineries also maintain a presence, and interests overseen, by a Northwest governmental affairs representative of the wine Institute of California, in both states. 153

These special interest representatives also participate in lobbying at the national level through the American Vintners' Association ${ }^{154}$ and its subordinate National Council of State wine organizations, ${ }^{155}$ and the government liaison committee of the Northwest Center for Small Fruit Research. ${ }^{156}$

\section{STRUCTURES OF STATE GOVERNMENTS}

While the cultures and politics of these states may be different, the state administrative structures are similar. There may in fact be some systemic element within the mechanisms for policy implementation that create different

${ }^{153}$ Interview with Washington wine Institute staff, November 9, 1993.

${ }^{154}$ Ibid. The American Vintners' Association was formed in 1992 as a merger of the Association of American Vintners and the National Vintners Association.

${ }^{155}$ Bill Nelson, "National Council of State Wine Organizations," Oregon Grapevine X:4, August-September 1993, p. 1 .

156" Organization of the Northwest Center for Small Fruit Research," Oregon Grapevine $\mathrm{x}: 4$, August-September 1993, pp. 13,17 . The committee has members from both oregon and washington wineries and both states' lobby groups, the Washington wine Institute and the Oregon Grapegrowers' Association. 
results in this area of economic development implementation. Both states' constitution were adopted (Oregon in 1859, Washington in 1889) as patterned after the U.S. Constitution and Bill of Rights. Both have been amended many times since then, and neither have been revised in totality. ${ }^{157}$

Both state governments follow the federal model, with Executive, Legislative and Judicial branches. Oregon's Legislative Assembly is a bicameral, part-time body with a 60 member House and a 30 member senate which meets biannually. Washington's Legislative Assembly is a bicameral, part-time body with a 98 member House and a 49 member Senate which meets annually.

The Executive Branch of each is headed by an elected Governor, who serves a four year term. There is no Lieutenant or Deputy Governor in Oregon, but Washington elects a Lieutenant Governor who need not be of the same political party as the Governor.

That part of Oregon's Executive Branch headed directly by the Governor consists of 20 departments. As discussed in the previous chapter, some departments are centralized and some decentralized in function: Agriculture; Corrections;

${ }^{157}$ Each biannual edition of the oregon Blue Book contains the oregon Constitution text. Three amendments to that document address liquor, all in Article $I$ : Prohibition in oregon occurred by initiative petition in 1914 (Section 36); prohibition of liquor imports at the same time (Section 36a); and authorization of liquor sales by the glass (Section 39). Washington's constitution has been amended 86 times, but no reference to national Prohibition was included. 
Energy; Economic Development; Environmental Quality;

Executive; Fish \& Wildlife; Forestry; General Services;

Geology \& Mineral Industries; Human Resources; Insurance \&

Finance; Land Conservation \& Development; Military; Parks \&

Recreation; Police; Revenue; Transportation; Veterans'

Affairs; and water Resources ${ }^{158}$

Washington's Executive Branch departments number 21, generally duplicating Oregon's under somewhat different names. Additional departments include: Blind Services; Employment Security; Labor \& Industries; Social \& Health Services. ${ }^{159}$

Oregon's departments of State, Justice, Education, Treasury and Labor and Industries are headed by separatelyelected officials. ${ }^{160}$ In washington, the departments of State, Justice, Audits, Treasury, Education, Insurance, and Public Lands are headed by independently-elected officials. Oregon has over two hundred autonomous and semiautonomous commissions, committees, boards and offices with varied legal and programmatic responsibilities within the Branch. Of particular interest are the oregon Liquor Control Commission, the Wine Advisory Board, the Traffic Safety Commission, Programs, and the Governor's Council on

${ }^{158}$ Ibid. , 1991, pp. 11-124.

${ }^{159}$ Richard and Charity Yates, 1992 washington State Yearbook (Olympia: State of Washington, 1992), pp. 49-88.

${ }^{160}$ Ibid., pp. 11-17. 
Alcohol and Drug Abuse Programs. WAB members are appointed by the director of the state Agriculture Department; members of the remaining groups are appointed by the Governor. ${ }^{161}$

washington has over 250 autonomous commissions, committees, boards and offices with varied legal and programmatic responsibilities within the Branch. Of particular interest are the Washington Liquor Control Board, the Wine Commission, the Traffic Safety Commission, and the council on Substance Abuse. ${ }^{162}$ wine Commission members are appointed by the Agriculture Department head; the Governor appoints WLCB members, with Senate approval, 42 of the 46-member Council on Substance Abuse, and the three non-statutory members of the Traffic Safety Commission. ${ }^{163}$

\section{ECONOMICS OF WINE}

Wine

As one recent author on wine has stated, "The focus of nearly all studies of wine economics is price."164 Models developed over the past several decades have concluded that, for vin ordinare, the price of a particular bottle of wine is positively correlated with harvest size (yield) and

\footnotetext{
${ }^{161}$ Oregon Blue Book, pp. 78-124.

${ }^{162}$ Ibid.

${ }^{163}$ Yates and Yates, 1992 Washington state Yearbook.

${ }^{164}$ Leo A. Loubere, The wine Revolution in France (Princeton, NJ: Princeton University Press, 1990), p. 163.
} 
government intervention, and negatively correlated with

imports. ${ }^{165}$

Almost uniformly, for table (lower cost) wines a 208 increase in unit price results in a 28 drop in sales, while

a 108 drop in price results in only a 18 increase in sales. ${ }^{166}$ The 10-to-1 elasticity ratio seems to hold both in an upward and a downward direction.

For premium (higher cost) wines, the price is positively correlated with harvest guality and the region of production. A 108 increase in price here will yield an estimated 5-7\% drop in sales -- a 2-to-1 elasticity ratio. ${ }^{167}$

As a result, an increase in premium wine price whether brought about by market forces or government-imposed fees and taxes will result in a drop in sales.

Wineries

Some sources report that, to begin a new Northwest winery from the vines up, costs an estimated minimum $\$ 1$ million. ${ }^{168}$ Most oregon and Washington wineries are small

${ }^{165}$ Ibid. , pp. 163-165.

${ }^{166}$ Ibid. , p. 165 .

${ }^{167}$ Ibjd. , Chapter 6.

${ }^{168}$ Lorianne Denne, "Cascade Cellars Uncorks $\$ 1$ Million Stock Sale," Puget Sound Business Journal 9:4 (1989), p. 5; Raymond J. Folwell and Mark A. Castaldi, "Economics of Size in Wineries and Impacts of Pricing and Product Mix Decisions," Agribusiness 3 (1987), pp. 28+. Others, looking only at the cost of producing the wine grapes, estimate an embedded 6-year cost of $\$ 1 / 4$ million -- see Tim Cross and Tim Casteel, Vineyard Economics: The Cost of Establishing and Producing 
family-run enterprises, started because of a hobby, a desire to shelter income, or to avoid large and increasing property tax bills on large acreages. ${ }^{169}$

In addition to the obvious components of investment in land, equipment, vines, preparation of the soil, chemicals, labor, and so forth, wineries because of their nature incur special costs. For example, festivals and events held on winery grounds attract wine-buying customers; insurance and liability concerns have led to creation of specialty insurance products to protect the business in the event of an injury sustained by such a customer. ${ }^{170}$

Few Northwest wineries financed by common stock exist. They include: Stimson Lane Wines and Spirits of Washington, a holding company and wholly owned subsidiary of U.S. Tobacco; ${ }^{171}$ Cascade Estates Winery of Washington; ${ }^{172}$ and

Wine Grapes in the Willamette Valley (Corvallis, OR: Oregon State University Extension Service, 1989).

${ }^{169}$ This data comes principally from wine maker interviews. Several doctors and other professionals have started vineyards as a method of sheltering income. Oregon's land use laws for rural areas, coupled with property taxation, favor growing a crop of some kind, and one winery was begun because the owner knew nothing about growing Christmas trees.

${ }^{170}$ Christopher Dauer, "Chubb Uncorks wine Insurance Program," National Underwriter (Property/Casualty/Employee Benefits) 95:47 (1991), pp. 17-18.

${ }^{171}$ Stimson Lane Wines \& Spirits in turn owns Chateau Ste. Michelle, Columbia Crest Winery, Whidbey's, and Saddle Mountain/Snoqualmie Winery in Washington, and Villa Mt. Eden and Conn Creek in California. Directory of the Wine Industry in North America -1992 (San Rafael, CA: The Hiaring Company, December 1991), p. 327. 
Willamette Valley vineyards of oregon. ${ }^{173}$ Capitalization of Cascade Cellars was fixed at $\$ 1$ million; the current (1993) capitalization of willamette Valley Vineyards is $\$ 4$ million.

size is another issue. The company publishing wines \& Vines annually ranks North American wineries by cooperage, or storage capacity, which in turn gives some indication of market share. In recent years, five Washington wineries have made the list of America's 100 largest wineries; none from Oregon has been listed. ${ }^{174}$

The relative smallness of Northwest wineries can work to their advantage. A 1990 federal tax bill, imposing increased per-gallon taxes on wineries, was amended not to apply to wineries with under 100,000 gallons per year production, thus exempting 988 of Northwest wineries. ${ }^{175}$

\section{Eoreign Investment}

Following 25 years of building a reputation for quality, the Northwest industry has begun to attract

${ }^{172}$ Lorianne Denne, "Stock Sale by Cascade Estates [Cellars] Goes Slowly," Puget Sound Business Journal, 10:17 (1989), p. 5 .

${ }^{173} \mathrm{Jim}$ Kadera, "Vineyard Launches Second Stock offering," The Oregonian (July 16, 1990), p. D8.

${ }^{174}$ Directory of the Wine Industry in North America, p. 327. The five Washington wineries are Stimson Lane, Coventry Vale vineyards, Hogue Cellars, Cascade Estates, and Columbia Winery. Three of Stimson Lane's holdings would individually make the list as well.

${ }^{175} \mathrm{Jim}$ Kadera, "[Senator] Packwood Still Pushing for winery Tax Exemptions," The Oregonian, October 16, 1990. 
investment from overseas. In 1987, the French wine maker Domaine Drouhin began a winery in oregon, seeking to make pinot noir wines similar to their French wines. ${ }^{176}$ Two years later, the French firm Laurent-Perrier also invested in Oregon vineyard land. ${ }^{177}$

The following year, a Washington winery was purchased by the Japanese firm Sapporo Breweries. ${ }^{178}$ In 1992, the Japanese sake producer Momokawa Sake opened a tasting room in Oregon, with the announced intent to produce an oregon sake from rice grown in the region. ${ }^{179}$

\section{Economics for the Social Good}

Often overlooked are the positive economic benefits of the wine industry associated with social agency fund raising. In the past 25 years, millions of dollars have been raised for a wide variety of charities and social service organizations, ${ }^{980}$ schools, $^{181}$ and health agencies ${ }^{182}$

${ }^{176}$ Matt Kramer, "Drouhin Investment gives Oregon a Prized French Connection," The oregonian September 11, 1987, p. D3.

177 Judy Peterson-Nedry, "Laurent-Perrier Buys Oregon Land," The Wine Spectator 14 (August 31, 1989), p. 15.

178 "Yakima Valley vineyard Purchased by Sapporo Breweries," The Olympian (June 29, 1990), p. B8.

${ }^{179}$ Momokawa Sake, Ltd., Connoisseur's Guide to Premium Sake (Forest Grove, OR: Momokawa Sake, 1992).

180 " $\$ 85,000$ Raised for Monastery," The wine spectator, June 15, 1990, p. 13; Thomas Matthews, "Million Dollar Weekend for Wine in Chicago," The wine Spectator, March 31, 1990, pp. 16-17; Thomas Matthews, "New York's Grandest Charity wine Auction," The Wine Spectator, December 15, 1991, p. 16; Thomas Matthews, "Wine Auctions Lucrative for Public TV," The Wine 
through wine tastings and auctions. To the extent permitted by law, wineries seem quite eager to serve as public minded citizens in these events.

Over the years, both oregon ${ }^{183}$ and Washington ${ }^{184}$ have proposed utilizing "sin taxes" on wine and other alcoholic beverages to benefit homelessness and drug/alcohol treatment programs. Iiquor taxes are also distributed to Oregon's General Fund and cities and counties on a population/pro rata basis to support general public services. ${ }^{185}$

The industry has also served as an opportunity for women seeking to utilize their wine making and business skills in a gender neutral environment to "make their mark"

Spectator, June 15, 1990, p. 13; \$20,000 Raised in Phoenix Theater Benefit," The Wine Spectator, May 15, 1990, p. 15.

${ }^{181}$ Robyn Bullard, "\$45,000 Raised for California School," The wine spectator, Vol. 15, 1990, p. 24.

${ }^{182}$ Oregon Chapter, American Cancer Society, Annual American Cancer Society Wine Tasting (Portland, OR: The Chapter, annually from 1986). Event booklets.

${ }^{183}$ Gail Kinsey Hill, "Roberts Sees sin Taxes as Best Hope," The Oregonian, January 24, 1993, p. C4.

184 "Brewers, Vintners Oppose Tax on Alcohol to Help Homeless," The Olympian, May 6, 1988, p. A7. However, a 20 cent per liter tax goes to the state's liquor revolving fund, to support alcoholism research at wSU and the University of Washington, and the state Social and Health Service Department.

${ }^{185}$ Secretary of State, Oregon Blue Book 1989-90 (Salem, OR: Secretary of State, 1989). In fiscal year 1987-88, some $\$ 56,687,000$ was distributed among Oregon governmental agencies from these taxes. 
in the work force. ${ }^{186}$

\section{SUMMARY}

This and the preceding chapter have focused on the first question asked in the Introductory Overview - what the literature has to say about public administration and policy as it relates to development of the wine industry.

Tables VI and VII summarize state administrative agencies, by typology, state and impacts ("pushes and pulls"). Both tables classify the agencies involved with the wine industry as "protective," "regulatory," "assistive," and "direct service" according to their principal role. Of course, each agency may consist of one or more elements of the other typologies.

For the most part, assistive and direct service agencies (with the notable exception of Revenue Departments, which are considered "redistributive") do not inspect for regulation compliance, levy fines or fees, or close facilities for violations. While the commodity commissions receive an industry-self-imposed tax, the actual collection is made by the Revenue Departments. In Washington, the Revenue Department also collects a $1 / 4$ cent per liter wine

186"First Winery Operates: Lois Herbolt Leading Way in Oregon," The sunday Oregonian, May 27, 1934, p. B2; susan Sokol-Blosser, "History and Character of the oregon Wine Industry," in Ted Casteel (Ed.), oregon Winegrape Growers' Guide (Portland, OR: Oregon Winegrape Growers' Association, 1992), pp. 1-3. 
tax to support grape/wine research and education for

Washington State University. ${ }^{187}$

\section{TABLE VI}

STATE ADMINISTRATIVE AGENCIES AND THEIR

ASSISTIVE IMPACTS ON THE WINE INDUSTRY, 1970-90

\begin{tabular}{|c|c|c|c|c|}
\hline TYPE /AGENCY & FTE & $\begin{array}{c}\text { winery } \\
\text { Education/ } \\
\text { Information }\end{array}$ & $\begin{array}{l}\text { Loans/ } \\
\text { Grants }\end{array}$ & Marketing \\
\hline & 오 트 & 오 트 & & Q $\underline{W}$ \\
\hline \multicolumn{5}{|l|}{ Protective } \\
\hline $\begin{array}{l}\text { Environmental } \\
\text { State Police }\end{array}$ & $\begin{array}{ll}x \\
x & x \\
x\end{array}$ & & & \\
\hline & & & & \\
\hline \multicolumn{5}{|l|}{ Regulatory } \\
\hline Health Dept. & $\mathrm{x} x$ & & & \\
\hline Labor Dept. & $x \times$ & & & \\
\hline Land Use Control & $\mathrm{x}$ & & & \\
\hline Liquor Control & $\mathrm{x} x$ & $x$ & & \\
\hline \multicolumn{5}{|l|}{ Assistive } \\
\hline Alcohol/Drug Com. & $\mathrm{x} x$ & $\mathrm{x} x$ & & \\
\hline $\begin{array}{l}\text { Economic Develop. } \\
\text { Revenue Dept. }\end{array}$ & $\begin{array}{ll}x & x \\
x & x\end{array}$ & $\mathrm{x}$ & $\mathrm{X}$ & \\
\hline \multicolumn{5}{|l|}{ Direct service } \\
\hline Agriculture Dept. & $\mathrm{x} x$ & $x \times$ & & \\
\hline $\begin{array}{l}\text { Commodity Comm. } \\
\text { Tourism Comm. }\end{array}$ & $\begin{array}{l}x \\
x\end{array}$ & $\begin{array}{l}x \quad x \\
x\end{array}$ & & $\begin{array}{l}x \\
x\end{array}$ \\
\hline Transportation & $\hat{x} x$ & $\mathrm{x} x$ & & $\hat{x}$ \\
\hline University/Educ. & $x x$ & $\mathrm{x} x$ & $\mathrm{X} *$ & \\
\hline
\end{tabular}

Key: FTE = Full Time Equivalent personnel fraction allocated; $0=$ Oregon; $W=$ Washington; $\mathrm{X}=$ present; Blank = absent

* Demonstration projects sponsored at specific wineries

All agencies in both states devote some full-timeequivalent personnel resources to the wine industry during 1970-90, with the exception of land use control and tourism

${ }^{187}$ RCWA $28 B$. 
support in Washington. Protective and regulatory bodies generally do not provide for education, grants, loans, or marketing assistance to the industry or individual wineries.

TABLE VII

STATE ADMINISTRATIVE AGENCIES AND THEIR RESTRAINING IMPACTS ON THE WINE INDUSTRY, 1970-1990

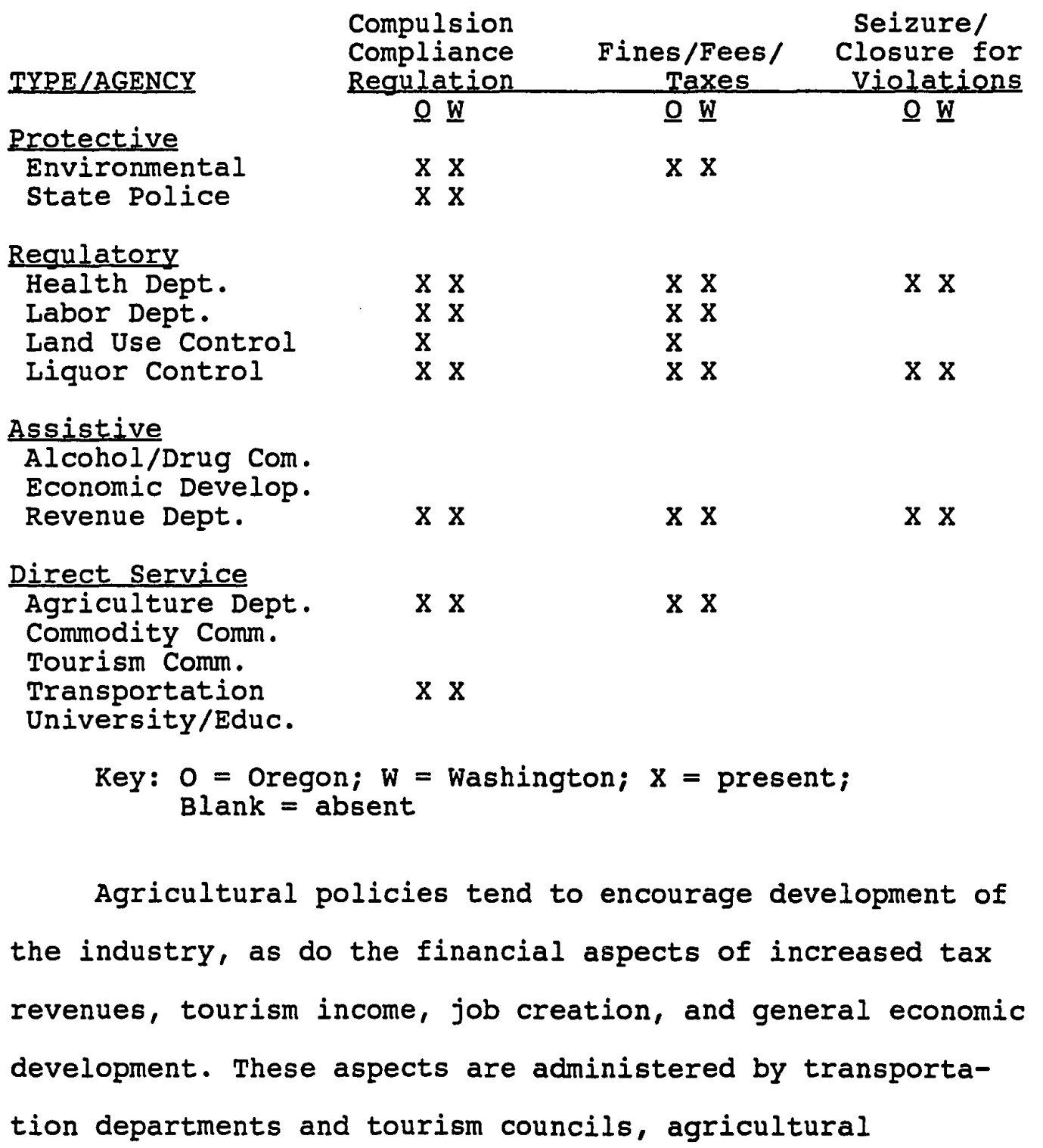


departments and their commodity commissions, land-grant universities, revenue and economic development departments, and labor bureaus. ${ }^{188}$

on the other hand, liquor control commissions seek to control and/or limit liquor consumption as a social evil. That control extends to distribution (in Washington); ensuring the moral character and training of servers, sellers and manufacturers; and monitoring sales to ensure that minors do not have access to alcohol.

Police departments are left to deal with those who consume to excess or who are not permitted to consume at all, and alcohol/drug agencies devise and operate programs to help those who cannot control addictive tendencies. ${ }^{189}$ Finally, some agencies are placed in totally ambiguous positions. Health agencies, charged with regulating the purity of wine, are faced with contradictory evidence of wine's ultimate health impacts while being forced to choose a course of action with or without federal funding. ${ }^{190}$

${ }^{188}$ These are what Ellis' typology of agencies would call either "direct-service" or "assistance/redistributive" organizations. It is reasonable to expect that the wine industry would perceive these agencies as positive and helpful. Walter G. Ellis, Typology of Administrative Organizations (Portland, OR: Portland State University, 1977), mimeo.

${ }^{189}$ Under the same typology, these would be classed as "protective" or "regulatory" agencies, whose actions would be perceived as negative or obstructive. Ellis, Ibid.

${ }^{190}$ Oregon's Health Division, for example, has apparently chosen to follow the federal dollar. Consuming two glasses of wine each day with meals, while perhaps gualitatively beneficial to cardiac health, is defined by Division adminis- 
Land use organizations seek to encourage stewardship of the land, but wineries also include manufacturing, wholesaling, and retailing aspects in what would ordinarily be exclusive farm use zones. Environmental quality offices applaud the minimal use of fertilizers and pesticides practiced by most wineries to maximize marketability of the finished product, but seek to control point-source discharge of wine making byproducts. ${ }^{191}$

trators as "chronic heavy drinking" along with liquor under the Surgeon General's quantitative guidelines. The Division has also adopted the position of the existence of the socalled "fetal alcohol syndrome." Oregon Health Division, Alcohol and Drugs in oregon, 1989 (Portland, OR: The Division, 1992), Chapters 3 and 4. Ellis would consider this agency to be "assistive;" Ibjd.

${ }^{199}$ Ellis' typology would call these agencies "protective," in that their functions are aimed at "preventing external forces or situations from adversely affecting society. Ibid. 


\begin{abstract}
I hear many cry when deplorable excesses happen, "Would there were no wine!" . . If you say, "Would there were no wine" because of the drunkards, then you must say, "Would there were no steel," because of the murderers, "Would there were no night," because of the thieves, "Would there were no light," because of the informers, "Would there were no women," because of adultery. ${ }^{192}$
\end{abstract}

Questions two through five asked in the Introductory Overview revolve around variables to be considered by public managers in helping new industry. What most effectively helps in encouraging the growth of new, start up industries, given that the policy of the state is to stimulate new industry and economic development?

While in some rare instances direct government policy can be cited for the existence of a particular winery (land use, taxation policies, loans), there may be some underlying forces which give different shape to an industry's development. The most logical places to look for foundations of an economic activity is where the money is: the product market and other, associated expenditures.

${ }^{192}$ Clifton Fadiman and Sam Aaron, The Joys of Wine (New York: Harry N. Abrams, Inc., 1975), p. 40, citing St. John Chrysostrom from his Homilies, 
INITIAL DATA

The policy of both Oregon and Washington is to stimulate economic development. ${ }^{193}$ Both states' per capita wine consumption have remained within about 108 of each other, at a level some 508 above that of the nation. ${ }^{194}$ Figure 3 illustrates the pattern from 1972 through 1990.

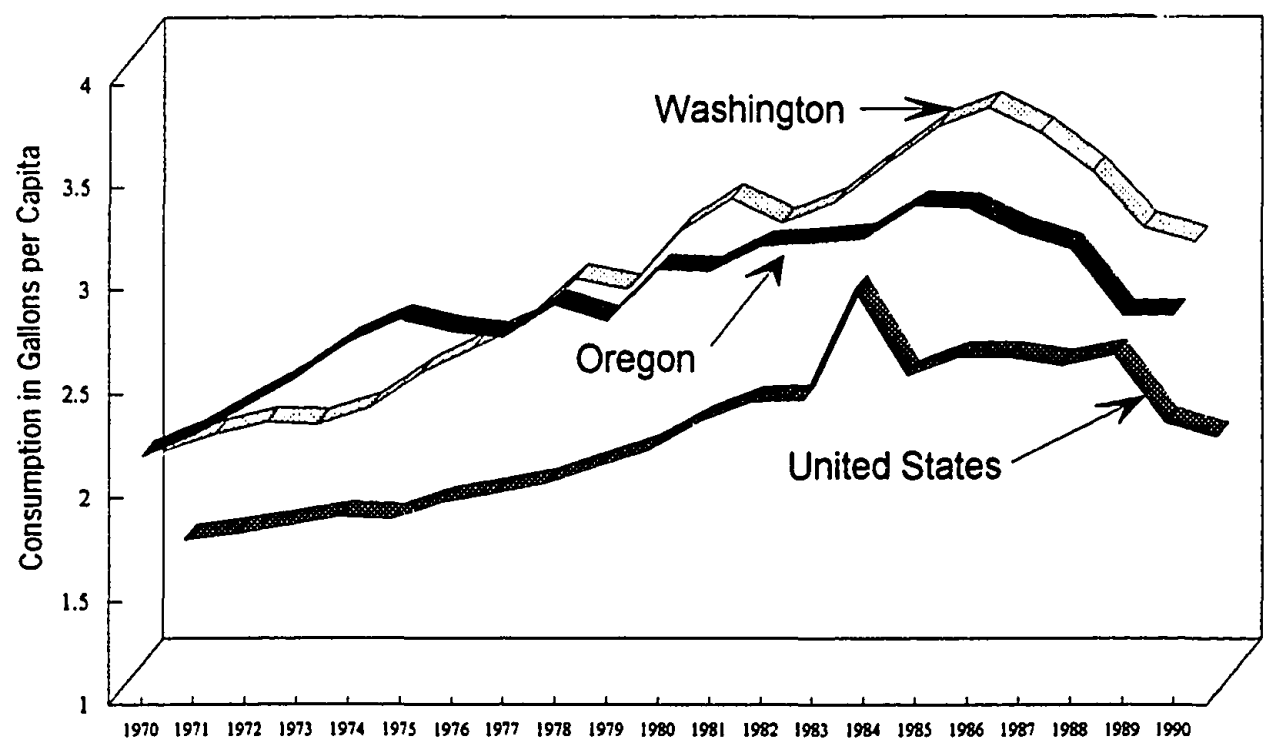

Figure 3. Per Capita wine Consumption.

Washington's population has over the last three censuses been between $160 \%$ and $170 \%$ that of Oregon's: $3,413,244$ versus $2,091,533$ in $1970 ; 4,132,180$ versus

${ }^{193}$ RCWA $43.21 \mathrm{H} ;$ ORS Chapter 184.

${ }^{194}$ Wines \& Vines annual statistical analysis, published in July of each year. 
$2,633,149$ in 1980 ; and $4,866,692$ versus $2,842,321$ in $1990 .^{195}$ If the industry dynamics were the same, washington should have 608 more wineries than Oregon, based on population.

However, this is not the case. Washington has fewer commercial wineries than has oregon (in 1993). A number of relevant factors must at this point be considered.

Consumption of wine in the two states is not solely dependent upon the existence of local wineries. The system is not closed. In 1992, oregon wineries produced 1,052,210 gallons of wine, of which 178 was shipped out of state.

Purchasers in Oregon bought (presumably for consumption) the remaining 878,342 gallons and:

$$
\begin{array}{lrl}
\text { from California } & 6,611,932 \text { gallons } \\
\text { from other US states } & 560,299 \text { gallons } \\
\text { from other nations } & 360,651 \text { gallons. }{ }^{196}
\end{array}
$$

In other words, Oregon wineries in 1992 had a 10.48 share of local markets. Washington numbers are closer to 208 .

For the moment, define a variable called "industry size" as being measured by the number of commercial wineries in operation at any time. One limitation of this measure is that all wineries are not comparable. Another limitation is

${ }^{195}$ US Department of Commerce, Census Bureau, Census of Population (Washington, D.C.: Government Printing Office, 1971, 1981, 1991).

${ }^{196}$ Oregon Liquor Control Commission, statement of wine Manufactured within or Imported into oregon as of December 1992 (Portland, OR: OLCC, 1993). 
that the economic contribution of all the non-winery firms listed in Table II is not directly considered.

Stimson Lane's massive presence with almost 8 million gallons of production capacity (19th largest in the nation) is hardly comparable to a small family-owned winery with production of 1,000 gallons. While there are other possible measures of this variable, the number of wineries is (a) simple, (b) available, and (c) relatively easy to measure. ${ }^{197}$

As discussed in the Introductory Overview, the industry is comprised of many components, and other measures are possible. ${ }^{198}$ Two factors limit the use of industry-wide data.

First, not all components are known. The small wine graphics house that designs wine labels as their sole business is identifiable, but the large advertising agency whose wine accounts make up $2 \%$ of their business, or the out-of-state foil maker, may not be known. This rules out

${ }^{197}$ It is also a generally-accepted substitute for the broader range of firms. See Jacques Delacroix and Anand Swaminathan, "Cosmetic, Speculative, and Adaptive Organizational Change in the Wine Industry, "Administrative Science Ouarterly $36: 4$, 1991, pp. 631-661; "Grapes of Rapture: Wine Industry in the Pacific Northwest," Pacific Northwest Magazine, July 1, 1989 , p. A34; and "Oregon 's Budding Table Wine Industry," Oregon Agri-Business, Winter $1977 / 78$, pp. 5-7.

${ }^{198}$ Considered but ruled out as candidates for the dependent variable included: total employment (together with the transitory nature of migrant workers) is not tabulated; total dollar sales, net income, total capital investment is often proprietary to small wineries or, while collected by IRS or state Revenue Departments, is not available even in aggregated form; data on market share and acreage planted and harvested is only available from the mid-1980's. 
industry employment, total sales, or net income as the dependent variable.

Second, financial data on all these components is not a matter of public record. Many bottlers, machinists, wholesalers, and so on are privately-held and do not make the financial extent of their involvement in the industry known. Using this variable definition, from Tables III and IV the pattern of industry growth in oregon and Washington can be seen to differ. A side-by-side comparison may be useful, as shown in Table VIII.

\section{TABLE VIII}

COMMERCIAL WINERIES IN OREGON AND WASHINGTON

Beginning of:

$$
1970
$$

1975

1980

1985

1990

1993

\section{Oregon}

3

11

22

40

83

99
Washington

3

3

20

61

83

85

This table is shown graphically in Figure 4 on the next page. The most striking difference is that the number of Oregon wineries is still on the increase as of 1993, while Washington's has leveled off. In part, mergers and acquisitions in washington approximately equal new winery creation; in Oregon, joint ventures and ownerships seem to be the rule rather than consolidations. 


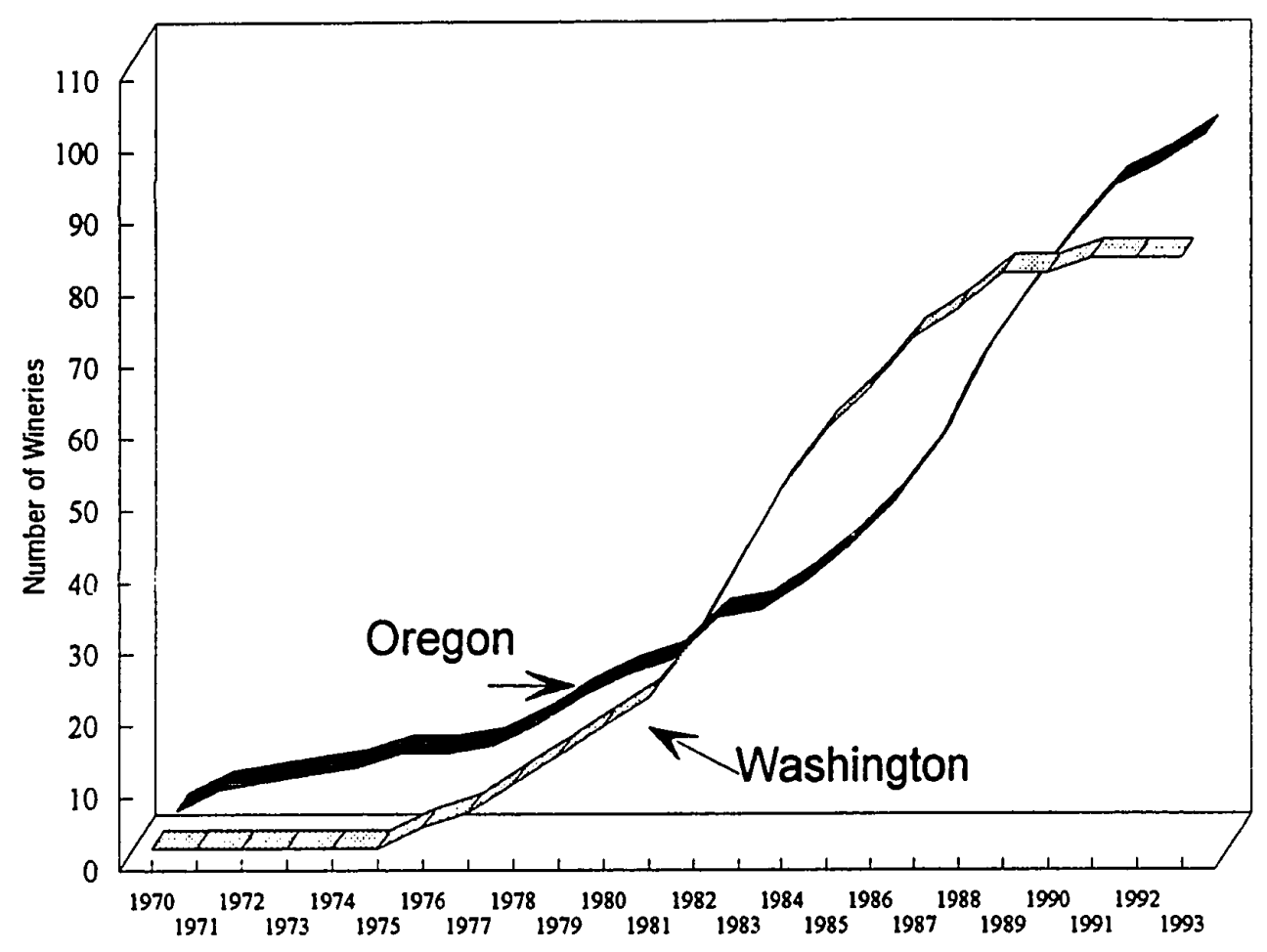

Eigure 4. Wineries in Oregon and Washington.

A robust model would be both explanatory and predictive. In a pure-market economy, the marketplace of supply and demand would explain the size of any given industry, that is,

$$
Y=f(X)+e
$$

where "Y" is the industry size, reflective of supply; " $f(X)$ " is read a "function of $\mathrm{X}, "$ " $\mathrm{X}$ " is a demand variable, and "e" is an error component.

As will be seen in the next chapter, however, market demand as reflected in consumption comprises only a portion 
of the explanation of variability of industry size in both states. At least two other factors must be at work, one of which restrains new entries into the market.

One negative force at work, as determined by interviews with wine makers, is market dominance. Washington has five of the largest 100 wineries in the nation, and in the early period between 1970 and 1980 the Stimson Lane Wines \& Spirits organization supplied enough wine to meet more than 808 of the state domestic market in production terms. Its size, coupled with a strategy of buying some smaller wineries and vineyards, may have produced some barriers to entry for some small wine makers. ${ }^{199}$

One clearly-identifiable source of positive incentive for this industry, from interviews and the literature, is government intervention in the form of loans, grants, education and marketing as provided by government policy, so that from [1] a preliminary model becomes:

$$
Y_{S}=f\left(X_{1}, X_{2}, X_{3}\right)+e
$$

where $Y_{S}$ is the number of commercial wineries in state $S, X_{1}$ is a measure of market demand, $x_{2}$ is a measure of government intervention, and $x_{3}$ is a measure of market dominance.

${ }^{199}$ There is also some evidence obtained from interviews that in the early $1960^{\prime} \mathrm{s}$, when Ste. Michelle was the largest winery of the dozen remaining in the Northwest, it opposed the creation and necessary permits for establishment of Columbia. Agency records contained nothing to confirm or deny this perception. 
"Government intervention" is the sum of government agencies and policies working both to promote the industry and to control or suppress the industry.

It is reasonable to expect, at the outset, that for Oregon and Washington there will be two equations, $Y_{O R}$ and $Y_{H A}$ different from each other, which represent the interrelationships of the variables under examination. Each state has a different number of wineries, slightly different consumption levels, clearly different patterns of government intervention, and different histories of winery growth patterns which might yield dominance effects.

If one knows consumption, the measure of government intervention, and whether a small number of wineries dominate the market, one may be able to predict the number of wineries in operation. The significance of this lies in the judgment that larger numbers of businesses represent a broader base upon which employment occurs, subsidiary local businesses and consultants are hired, taxes are levied, and financial activity takes place. Governments may be able to actively encourage the growth of an industry through entry of new firms.

Other possible sources of financial incentive are some type of private, federal or local government support. However, neither the literature nor extensive interviewing suggests any such alternatives exist in either state. 
METHODS AND TECHNIQUES

Once the question has arisen -- what is different between Oregon and Washington that encourages winery numbers to develop at different rates -- then several steps must follow. First, a definition and refining of the research question must take place, and from that research question an hypothesis.

Equation [2] represents one model of elements that can be identified and related one to another to define that hypothesis: Winery numbers $\mathrm{Y}$ in state $\mathrm{S}$ are directly related to at least three independent variables at work in that state. A secondary hypothesis is that the equation that is derived for oregon is likely to be different from that derived for washington, i.e.,

$$
Y_{O R}=/=Y_{W A}
$$

TIME FRAME

A limit must be placed upon data collection, both for analytical and for practical reasons. The time frame chosen for this study is 1970-1990. The beginning of the period is chosen for the availability of data, the approximate date of resurgence of the wine industry in each state, and the start of organized state efforts at economic development.

The ending date is chosen arbitrarily, being the time at which data was available just after the initiation of 
this study in 1991. Examination of data for 1991 and 1992 shows no significant deviations from the patterns established in the base period.

\section{VARIABLES}

For the dependent variable, candidates included:

- industry employment

- industry gross sales

- industry net income

- aggregate winery sales

- industry gross capital investment

- aggregate winery capital investment

- growth in state domestic market share by that state's wineries

- vineyard producing acreage

- number of wineries.

For the reasons previously discussed, number of operating, commercial wineries was selected. Prior to that selection, interviews were conducted among wine makers and government officials, and the literature was searched. The purpose was to identify theoretical and practical candidates for variables which might explain a state's industry size as measured by number of wineries (the dependent variable).

From the model description in the previous chapter, three independent variables are identified. The market demand variable, $x_{1}$, is per capita consumption times 
population. Per capita consumption numbers are taken from the July issue of Wines \& Vines, a trade publication. Population is taken from U.S. Census Bureau reports. Missing data is estimated by straight-line interpolation between known data points.

The government intervention variable, $x_{2}$, is a bit more difficult to estimate. State agency records do not separate out a one-tenth full-time-equivalent (FTE) salaried position to conduct winery health inspections. The same inspector may also be inspecting meat-packing plants, strawberry processors, and so on. It is far easier to determine when and for how much a lottery-fund grant was made.

First, a pattern of government agency participation over time was established for each state. For instance, health, agricultural, tax and liquor control agencies impacted wineries over the total period under study, while wine commissions, economic development departments, and tourism agencies began wine-related programs in mid-period.

Next, the total government funds for each agency devoted to wine industry regulation or assistance was estimated, based upon personnel allocation, budgets, reports, incident investigations, and noted events such as loans or grants made.

Total expenditures may not tell the story of whether money was spent to support industry growth or rather to control and suppress it. A mechanism was desired to 
determine whether a theoretical help/obstruct classification of agencies ${ }^{200}$ could be corroborated by empirical data. The market dominance variable, $x_{3}$, is a bipolar, 0 or 1, number indicating whether a small number of wineries are making more than half the sales of a state's wineries within the state domestic market in a given year. Data is collected from news and trade publication stories, and interviews. These variables were selected from a much larger list of candidates, including:

- total producing acreage

- interest rates

- total value of domestic state wine sales

- total value of all wine sales

- unemployment rates

- gross population

- total personal income in each state

- total disposable personal income in each state

- presence of an oligopoly

- government full-time-equivalent personnel devoted to the industry

- number of government programs devoted to the industry

- government dollars directed to the industry in the form of grants, loans, and other

${ }^{200}$ Ellis, Op cit. 
programmatic elements (research, education)

- government budgeted expenditures.

Most of these candidates were rejected because the data either: was not collected; was collected but unavailable because they represented protected records of IRS or state Revenue Departments; was proprietary; had substantial gaps over the time period being studied; or were not available at the state level.

Once the variables were selected, data was collected and aggregated. Aggregated were $x_{1}$, which is the product of population times per-capita consumption and $x_{2}$, which is the sum of all governmental monies expended from all agencies with a policy interest in the industry. Estimates based upon straight-line interpolation between known data points were made were data were not available.

Simple linear regression was performed on the number of wineries versus each independent variable. Subsequently, multiple regression was performed on combinations on the independent variables versus the number of wineries. The results were then discussed and reviewed with colleagues for possible flaws in the theory, data collection methodology, and analytical techniques. 


\title{
CHAPTER V
}

OBSERVATIONS

\begin{abstract}
All of these new viticultural regions of the Northwest are so individual in their ecological structure, producing their own incomparable wines -- some with a specific varietal freshness, some with an amazing depth, and some with artistic elegance and such an exciting vivacity. ${ }^{201}$
\end{abstract}

WINERY DATA

At the beginning of each year, in each state, the total number of commercial, operational wineries in existence were counted. This count included all wineries with founding dates preceding January 1st which reported wine production, less those who during the year stopped producing due to: [1] bankruptcy; [2] had legal action in process which suspended operations (divorce, probate, lawsuits); [3] had merged into another winery; [4] had been bought out; or [5] the owner simply "walked away" from the business.

The count is listed in Table VIII, for each state, as dependent variable $Y$.

\section{VARIABLE DATA}

Data was collected as described on each variable.

${ }^{201}$ Andre Tchelistcheff, in Purser, op cit., p. 3. 


\section{Market Consumption}

As stated in the preceding chapter, strength of the market in each state is calculated by multiplying each state's population times per capita consumption. Population between censuses is estimated via straight-line interpolation; per capita consumption is from Wines \& Vines July statistical reports, with missing data estimated via straight-line interpolation.

This data is listed in Table IX, for each state, as independent variable $\mathrm{x}_{1}$.

\section{Net Government Intervention}

As described in the previous chapter on methodology, the independent variable $x_{2}$ is computed by summing, in each year, estimates of all relevant state agency expenditures.

\section{Market Dominance}

Market dominance, or independent variable $x_{3}$, is not a particular issue in Oregon. While in the first 5 years of the study period one or two wineries could be said to have dominated the industry, by 1975 no two or three wineries had control of more than $50 \%$ of sales within the state.

On the other hand, Stimson Lane's Ste. Michelle and other holdings dominate the Washington domestic market through survivorship, sheer size, and acquisitions.

In 1990, Washington's five largest wineries had the storage/production capability of annually producing over 10 
million gallons of wine. About 758 of this is sold instate, or 7.5 million out of the total 15.1 million consumed by Washingtonians. The pattern for Washington described in Table VII is an estimate based upon newspaper and trade journal reports, and upon interviews with wine makers in both Washington and Oregon.

What is present in Table IX, then, is the accumulated data and processed estimates of what is in essence a time series relationship, measured in two state subsamples.

TABLE IX

COLLECTED/PROCESSED DATA, OREGON AND WASHINGTON WINE INDUSTRY

OREGON $\underset{\text { Consum. Gov't. }}{x_{1}} \mathrm{x}_{3}$ Win- 000's Expend Mkt Year eries Gallons (\$OOO) Dom

\begin{tabular}{lrrrr|}
1970 & 3 & 4,602 & 10 & 1 \\
1971 & 6 & 4,943 & 10 & 1 \\
1972 & 7 & 5,383 & 10 & 1 \\
1973 & 9 & 5,839 & 11 & 1 \\
1974 & 9 & 6,380 & 11 & 1 \\
1975 & 11 & 6,798 & 11 & 0 \\
1976 & 11 & 6,815 & 12 & 0 \\
1977 & 12 & 6,900 & 13 & 0 \\
1978 & 15 & 7,466 & 28 & 0 \\
1979 & 19 & 7,424 & 28 & 0 \\
1980 & 22 & 8,255 & 119 & 0 \\
1981 & 24 & 8,284 & 135 & 0 \\
1982 & 30 & 8,664 & 140 & 0 \\
1983 & 31 & 8,776 & 191 & 0 \\
1984 & 35 & 8,889 & 250 & 0 \\
1985 & 40 & 9,388 & 338 & 0 \\
1986 & 46 & 9,421 & 388 & 0 \\
1987 & 54 & 9,148 & 741 & 0 \\
1988 & 66 & 8,982 & 611 & 0 \\
1989 & 75 & 8,136 & 715 & 0 \\
1990 & 83 & 8,185 & 728 & 0
\end{tabular}

WASHINGTON

$$
Y \quad x_{1} \quad x_{2}, x_{3}
$$
Win- 000's Expend Mkt eries Gallons (S000) Dom

$\begin{array}{rrrr}3 & 7,167 & 9 & 1 \\ 3 & 7,597 & 9 & 1 \\ 3 & 7,968 & 10 & 1 \\ 3 & 8,093 & 10 & 1 \\ 3 & 8,549 & 10 & 1 \\ 3 & 9,357 & 11 & 1 \\ 6 & 9,997 & 11 & 1 \\ 8 & 10,615 & 13 & 1 \\ 12 & 11,688 & 14 & 0 \\ 16 & 11,696 & 14 & 0 \\ 20 & 13,057 & 14 & 0 \\ 24 & 13,964 & 18 & 0 \\ 32 & 13,696 & 38 & 0 \\ 43 & 14,368 & 79 & 0 \\ 53 & 15,454 & 115 & 0 \\ 61 & 16,522 & 161 & 0 \\ 67 & 17,206 & 176 & 0 \\ 74 & 16,926 & 234 & 1 \\ 78 & 16,298 & 404 & 1 \\ 83 & 15,258 & 446 & 1 \\ 83 & 15,136 & 658 & 1\end{array}$


ANALYSIS

The first question to ask is, "Are the industries in Oregon and Washington really different?" The answer, both from the raw data in Tables VIII and IX and from statistical analysis, is "Yes."

First, when the data of Table VII are considered, the Oregon industry continues to grow while washington's seems to be flattening out. Second, Washington's winery size differential, including five of the nation's 100 largest wineries, means those wineries dominate the washington industry. Oregon's wineries are relatively small and share proportionately in the local market.

Third, Oregon supports the same number of wineries over this time frame with only 608 of the population of Washington. Fourth, Oregon government expenditure policy seems to favor the industry about 2-to-1 over Washington's. Finally, the median (half above, half below) production by wineries in Oregon is higher than Washington, 5,600 gallons versus 5,300 gallons in 1989).

To test these suspected differences, a statistical test of difference of means was applied against two composite measures over the time frame. The first measure looked at in-state consumption of locally-produced wine on a perwinery mean basis. The second looked at mean per capita government expenditures for the winery industry. 
Results of these comparisons are found in Table $\mathrm{X}$. First assuming that the two industries (groups) are the different from one another, the "null hypothesis" is that they are identical.

The net result of comparing the two is that they are different from one another. The probability of the differences in both measures are less than 18 that the groups are drawn randomly from the same sample; the null hypothesis is rejected for both.

TABLE X INDUSTRY DIFFERENCES, OREGON AND WASHINGTON

\section{Oregon Washington}

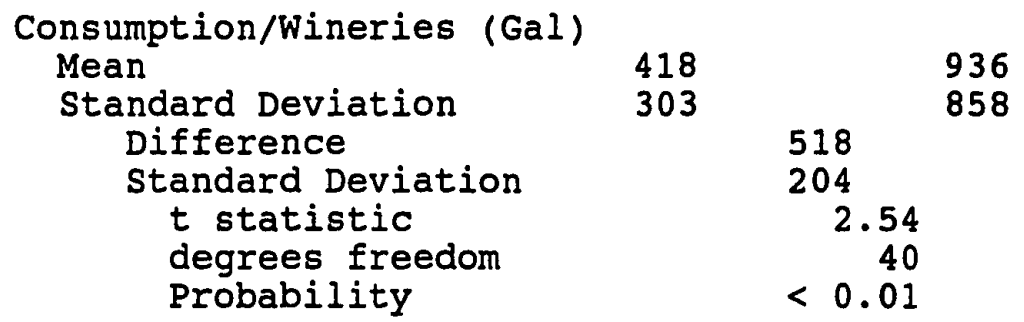

Government Expenditure/Population (\$) Mean

Standard Deviation Difference Standard Deviation $t$ statistic degrees freedom Probability

$\begin{array}{rr}21.2 & \\ 25.0 & \\ & 15.5 \\ & 5.9 \\ 2.63 \\ 40 \\ <0.01\end{array}$

5.7

8.6

.9

40

Table $x$ illustrates that, in terms of average size, Washington wineries are significantly larger in a statistical sense. However, as previously noted, in terms 
of median size, Oregon wineries are larger in terms of perwinery production, the difference being the overwhelming production of Washington's five very large wineries. Additionally, Oregon spends (statistically) significantly more money per capita on the wine industry than does washington. Two additional methods of analysis are applied against the Table $X$ data. First, a curve-fitting methodology which seeks to estimate the growth of the industry in each state over time. This method seeks to find an equation which provides a "best fit," ignoring specific variables in favor of a time series.

The second method is that of multiple linear regression, which seeks to find the "best" linear model (equation) which utilizes the three independent variables to predict the dependent variable, the number of wineries.

\section{Curve Fitting}

Curve-fitting is often the least "scientific," and most artistic or craft-related, component of an analysis. Its purpose is to determine whether a time-related pattern exists, and may offer support to the influence of some variables. An examination of Figure 4, shows two different patterns of development in the period 1970-1993 of the number of wineries in each state.

Clearly over time the relationship is not likely linear; a straight line may not be the "best fit." Business 
professionals or mathematicians, knowing (or guessing) that the numbers that make up the points in Figure 4 are business-related, might guess that one or both are cyclic. ${ }^{202}$ From the graph scale in the figure, the cycles are neither Kitchin (a 40-month cycle) nor Juglar (an intermediate, 9 to 10 year cycle). The cyclic period, which appears to be a sine (or cosine) function, is about 40 to 50 years. ${ }^{203}$

A process called Newtonian iteration, wherein a series of "educated guesses" gradually spirals in on an appropriate equation, reveals an equation (where $\mathrm{x}=$ time) which closely matches the Washington data:

$$
Y_{H A}=41+40 * \cos 0.175[x-1991.4]
$$

While the equation looks very unwieldy, it provides a close match to the measured data, and suggests that with time as the independent variable the Washington wine industry is headed for a lessening of numbers.

Figure 5 on the following page shows the graphical differences between the real-world data and equation [4].

${ }^{202}$ The author holds a bachelor's degree in mathematics, and performed one year's graduate study in the field.

${ }^{203}$ Douglas Greenwald et al., The McGraw-Hill Dictionary of Modern Economics (New York: McGraw-Hill, 1984). 3rd Edition. See also A. Burns and W. Mitchell, Measuring Business Cycles (Cambridge, MA: National Bureau of Economic Research, 1946); J. Stock, "Measuring Business Cycle Time," Journal of Political Economy 56: 1987, pp. 1240-1261; and Salih $N$. Neftci, "Statistical Analysis of Shapes in Macroeconomic Time Series: Is There a Business Cycle?" Journal of Business and Economic Statistics 11:2, April 1993, pp. 215-224. 
As a time series, the number of Washington wineries is clearly not linear. This in turn implies that a series of factors are involved that change over time (market, dominance, mergers, purchases) which lead to the presence of a particular number of wineries.

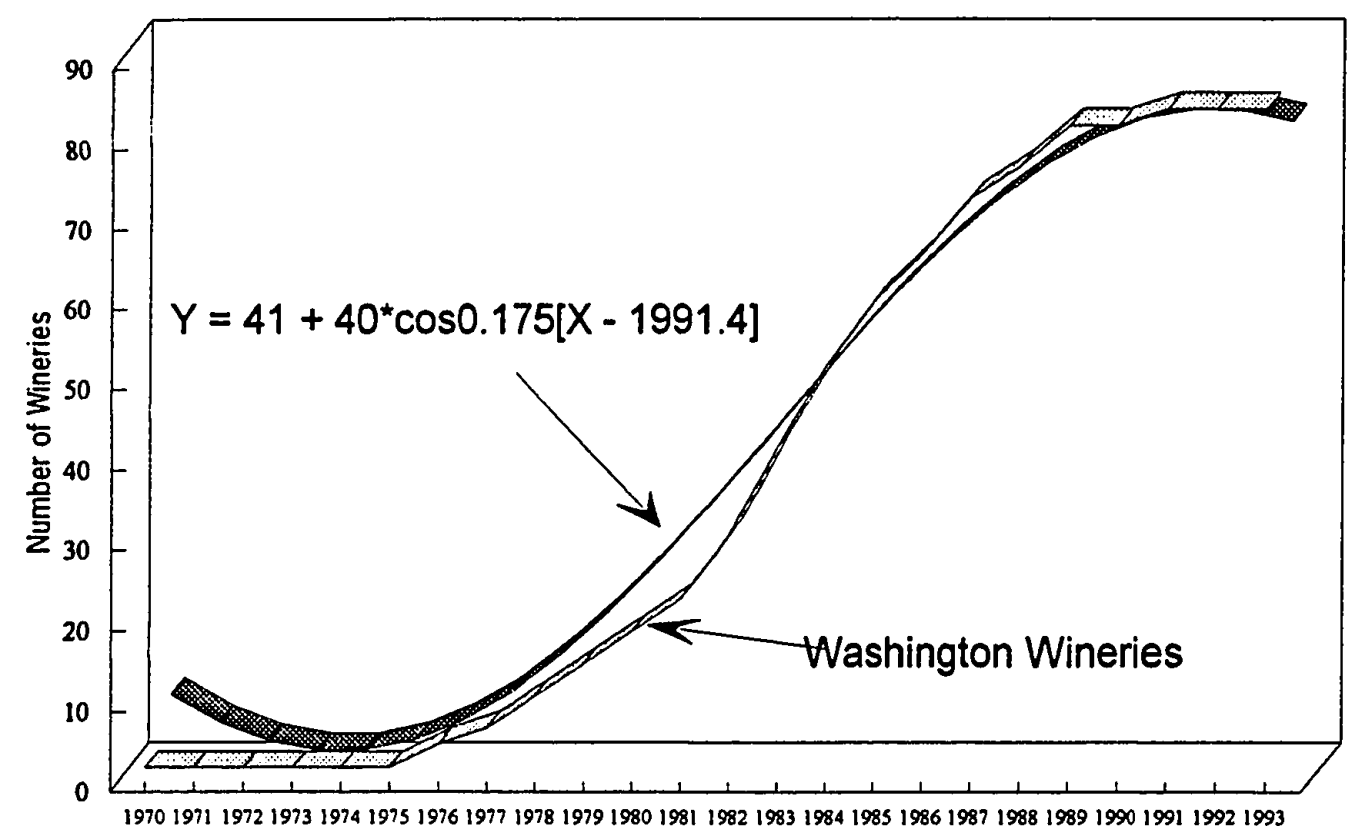

Eigure 5. Washington Wineries as Time Series.

Newtonian iteration also yields an equation which closely matches the oregon data. However, this equation is the positive portion of a parabola, rather than a segment of a cosine equation:

$$
Y_{O R}=3+0.189 *[X-1970]^{2}
$$


This equation also looks unwieldy, but it does provides a close match to the measured data, and suggests that with time as the independent variable the oregon wine industry is headed for increasing numbers, at least over the short run. This fits with that industry's recent history of adding four to six new wineries each year. Figure 6 shows the graphical comparison between the real-world data and equation [5].

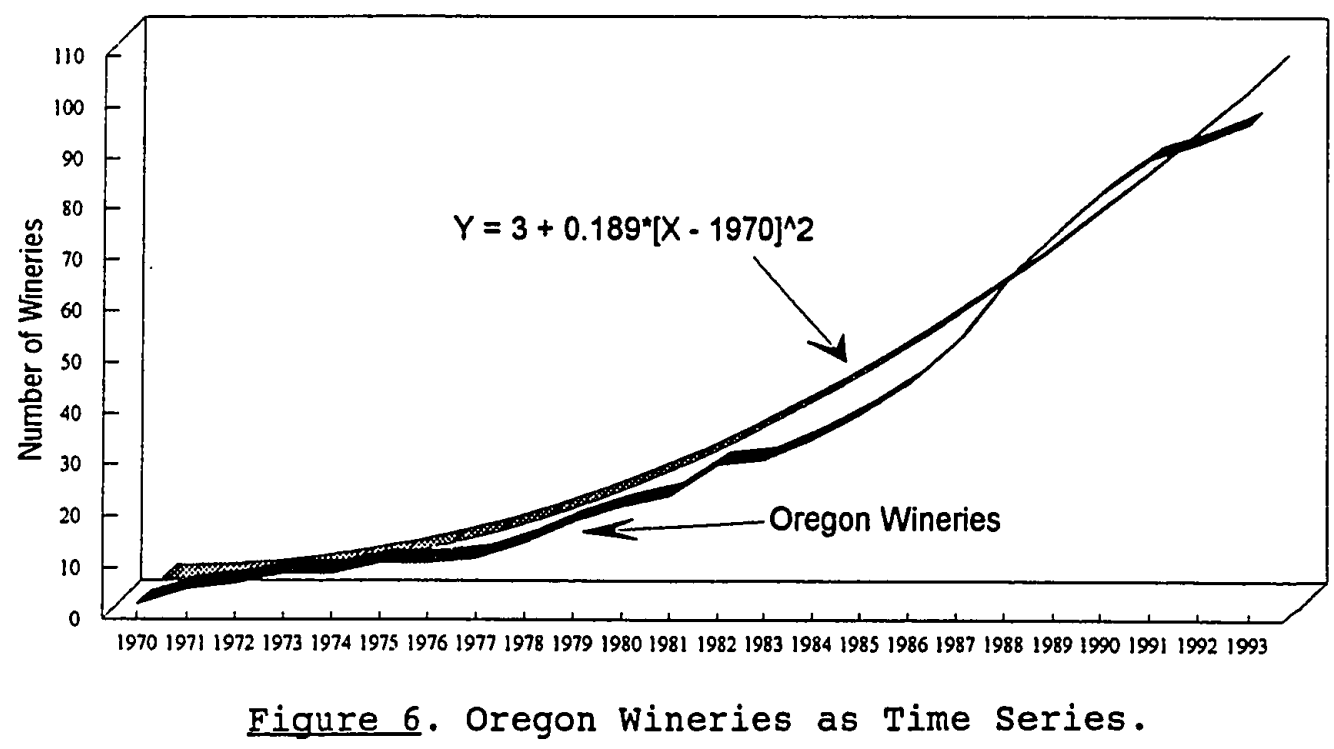

An alternate curve-fit for Oregon might reveal that the curve is also a cosine function, but with a longer period and higher amplitude. No cosine curve fitted matched the data as closely as equation [5], but if such growth is a part of a long-term business cycle, the downturn must lie 
somewhere ahead in time. ${ }^{204}$

\section{Regression}

The numerical data from Table VII allows the creation, through multiple regression, of linear equations (straight lines) for the growth of oregon and Washington wine industries over time. Although the growth curves visually are clearly not linear, the method of least squares regression allows an evaluation of the linear association between the independent variables $x_{i}$ and the variable industry size $Y$.

In regression analysis, two key numbers are generated as well as the linear equations. The first is the coefficient of each independent variable, which indicates the positive or negative relationship between it and the dependent variable.

The second is called the "coefficient of determination," or $\mathrm{R}^{2}$, which is a measure of association as to how linear the two (or more) variables are.

Finally, it should be noted that the variables $x_{1}, x_{2}$, and $x_{3}$ are in different units: gallons, dollars, and yes/no. A transformation of variable coefficients is needed to

${ }^{204}$ Several Oregon wine makers, including Bill fuller of Tualatin and Joe Campbell of Elk Cove, indicated during interviews that there is an expected downturn, or "shake-out," coming for the oregon industry. Unexpected closures, such as that of Forgeron winery in Eugene for inability to meet bank loans, may be the beginning of that trend. 
standardize the impacts of the independent variables on the dependent variable industry size. This transformation, which multiplies the coefficients by ratios of standard deviations, creates a "Beta" coefficient, which allows a direct comparison of the impacts of each variable.

Table XI demonstrates relationships (or lack thereof) among the dependent variable $\mathrm{Y}=$ industry size, $\mathrm{X}_{1}=$ market consumption, $x_{2}=$ net government intervention, and $x_{3}=$ market dominance for the data in the state of Oregon. The multiple regression equation for Oregon is:

$$
\begin{aligned}
Y_{O R}=15.3-0.001 X_{1} & +0.326 X_{2} \\
& -7.577 X_{3}
\end{aligned}
$$

and the table is constructed as follows:

TABLE XI

OREGON INDUSTRY REGRESSION SUMMARY

\begin{tabular}{llll}
$Y_{O R}$ & $x_{1}$ & $x_{2}$ & $x_{3}$ \\
\hline Simple Regression
\end{tabular}

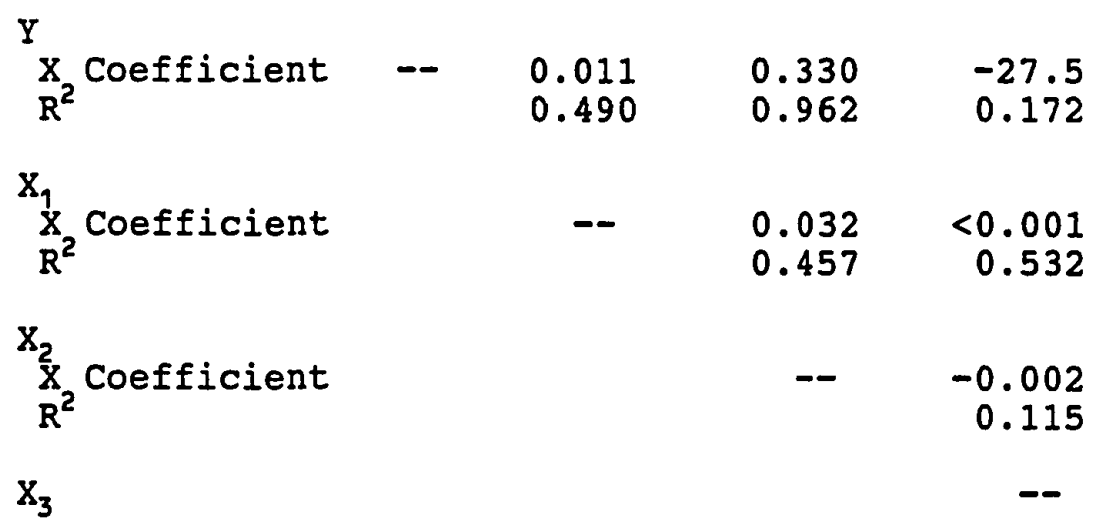


TABLE XI

OREGON INDUSTRY REGRESSION SUMMARY (continued)

$\begin{array}{llll}Y_{O R} & x_{1} & x_{2} & x_{3} \\ \text { Multiple Regression }\end{array}$

$$
\begin{array}{lccc}
\mathrm{Y} & \multicolumn{1}{c}{0.326} & -7.577 \\
\mathrm{R}_{2} \text { Coefficient }-- & -0.001 & 0.326 & \\
\text { Beta Transformation } & -0.037 & 0.967 & -0.114
\end{array}
$$

The $R^{2}$ value is 0.952 . Some 958 of the variation in industry size $Y_{O R}$ as a linear equation is accounted for by the variations in $x_{1}, x_{2}$, and $x_{3}, y_{O R}$ is positively related to market consumption and net government expenditure, and negatively related to market dominance under simple regression ( $\mathrm{Y}$ vs $\mathrm{X}_{1}$, etc.).

Under multiple regression, $Y_{O R}$ is essentially neutral with regard to market consumption (the Beta is almost "0"), very positively related to net government expenditure, and negatively related to market domination, as shown by the Beta transformations. The sum of Betas should equal $R^{2}$, but in fact fall short by 0.157 , which implies the presence of an unknown factor.

Table XII demonstrates the same data for Washington values. The multiple regression equation for washington is:

$$
\begin{aligned}
Y_{W A}=-44.48+0.005 X_{1} & +0.326 X_{2} \\
& +7.05 X_{3}
\end{aligned}
$$


with an $R^{2}$ value of 0.947 . This may be interpreted as 94.78 of the variability in $\mathrm{Y}_{\mathrm{HA}}$ being explained by the variations in the $x_{i}$ independent variables.

TABLE XII

WASHINGTON INDUSTRY REGRESSION SUMMARY

\begin{tabular}{llll}
$Y_{H A}$ & $x_{1}$ & $x_{2}$ & $x_{3}$ \\
\hline Simple Regression
\end{tabular}

\begin{tabular}{|c|c|c|c|c|}
\hline \multicolumn{5}{|l|}{ Y } \\
\hline $\begin{array}{l}\mathrm{X}_{\mathrm{R}^{2}} \text { Coefficient } \\
\text {. }\end{array}$ & --- & $\begin{array}{l}0.008 \\
0.810\end{array}$ & $\begin{array}{l}0.703 \\
0.865\end{array}$ & $\begin{array}{l}14.89 \\
0.060\end{array}$ \\
\hline$\underset{\mathrm{R}^{2}}{\mathrm{X}_{1}}$ coefficient & & --- & $\begin{array}{l}0.009 \\
0.514\end{array}$ & $\begin{array}{r}<0.001 \\
0.007\end{array}$ \\
\hline${ }_{R^{2}}^{X_{2}}$ Coefficient & & & -- & $\begin{array}{l}0.005 \\
0.131\end{array}$ \\
\hline
\end{tabular}

Multiple Regression

$$
\begin{aligned}
& Y \\
& \mathrm{R}_{\mathrm{R}^{2}} \text { Coefficient }--0 \quad 0.005 \quad 0.366 \quad 7.054 \\
& \begin{array}{llll}
\text { Beta Transformation } & 0.562 & 0.485 & 0.116
\end{array}
\end{aligned}
$$


the sum of the Betas exceeds $R^{2}$, by 0.178 , which again

implies the presence of an unknown factor greater in magnitude than market dominance.

In sumary, then, the independent variables examined account for almost 958 of the variability in the number of Washington wineries. The statistical interpretation is that at least one other variable is involved, probably a negative element, which influences the presence of a number of wineries at a given point in time. 


\title{
CHAPTER VI
}

\section{CONCLUSIONS AND RECOMMENDATIONS}

\begin{abstract}
And much as wine has play'd the Infidel, And robb'd me of my Robe of Honour - well, I wonder often what the vintners buy One-half so precious as the Stuff they sell. ${ }^{205}$
\end{abstract}

\section{COMMENTARY}

From an economic viewpoint, the supply of consumer products rise and fall with demand. Supply by a few firms or many should have little impact upon the marketplace itself, except as to price, or to limit or expand choice.

Government intervention at the consumer level usually takes the form of restrictions on product availability (tobacco, alcohol, drugs) or warnings. At the corporate level, it may take the form of targeting production to encourage a limited number of firms to enter a specific field (orphan drugs, nuclear weapons).

The Oregon experience implies that administrative policy choices can encourage creation of new firms for commercially producing wine. While aggregate consumption is also an important factor, state agency expenditures appear

${ }^{205}$ The Rubaiyat of Omar Khayyam, translated by Edward Fitzgerald (Mount Vernon, NY: Peter Pauper Press, n.d.). 
to be positively correlated with the growth in this

component of the state's economy. There is little or no evidence of the current existence of an oligopoly which might limit entry into the commercial wine making field.

On the other hand, Washington's experience implies that the number of commercial wine producing firms is driven by consumption, and only weakly correlated with state agency expenditures. While at various times a small number of wineries appears to have dominated production and market share, such an apparent oligopoly seems to have had little or no impact upon the marketplace entry of new firms.

The mechanics of these variables - government expenditures, consumption, and oligopoly - over the period of time studied have non-identical impacts in the two states, in accordance with the original prediction (equation [3]).

\section{INTERPRETATION}

What does the data and analysis herein mean in terms of policy and prediction? Given that Washington's winery data are skewed by a few, very large firms and Oregon's are not, can any inferences be drawn regarding size or numbers which might have implications for government courses of action?

In Washington, university research and education programs related to grapes and wine are funded with a tax on each liter of production, as well as each ton of grapes picked. The wine Commission is funded by a similar tax, the 
majority of which is collected from stimson Lane wines \& Spirits as the largest seller of wines in the state. ${ }^{206}$

One interpretation which could be made is that the Washington State University research programs and the wine Commission marketing programs principally benefit stimson Lane (and the other largest wineries). These two government expenditures make up the largest part of Washington's total spending for the wine industry.

More government spending in these areas, reflective of higher sales, might then primarily serve a few large wineries, with the smaller wineries receiving only a marginal benefit. The bigger wineries would be assisted with government programs to help them grow bigger still, with the rest of the industry just "along for the ride."

Lower relevant government expenditures ${ }^{207}$ would then most likely come in inspections and tourism-related activities such as road signage. Smaller wineries rely on signs to attract buyers to their tasting rooms, so that a reduction in this program would likely result in lower sales. For some wineries, this reduction might be enough to make them vulnerable to acquisition or force them out of

${ }^{206}$ See footnotes 56 and 57 .

${ }^{207}$ Which may be imposed by a November 1993 voter initiative placing a cap on total state program spending (measure 601). 
business, 208 having the result of making some big wineries bigger or creating new large wineries through merger. The number of wineries would shrink, as would employment for many of the ancillary firms listed in Table II.

In washington, however, the overriding factor in industry growth appears to be consumption. A change in relevant government spending might have only a small impact on the number of wineries in business.

A similar picture might be painted of Oregon, with the exception of the absence of large wineries at the beginning. Tourist signage is run on a pay-as-you-go basis, with wineries paying for each sign.

Government programs and spending supported by industry levies on its own sales would continue to grow only if sales and consumption continue to grow, with the benefits perhaps more evenly spread. Just how to keep sales growing is a subject of intense debate, ${ }^{209}$ and the results presented herein indicate that consumption may be less important to the Oregon industry than government support.

The other principal source of government spending for wineries in Oregon is its lottery games, monies which are funneled to the local level directly, or through regional

${ }^{208}$ From the author's own experience, and from wine maker interviews, winery tasting rooms can represent 5\%-7\% of a winery's total sales to the public.

${ }^{209}$ Denis Burger, "The wine Market: What is Really Happening?" Oregon Grapevine X:5, October-November 1993, pp. 1+. 
councils, via the Economic Development Department. As competition for this resource grows, ${ }^{210}$ diversion away from economic development would limit or eliminate these monies from support of individual wineries. ${ }^{211}$

Reduction of relevant government spending in Oregon might well result in a reduction in the number of wineries. With no large "flagship" wineries and no strong history of acquisitions and mergers, the fate of the remaining firms is unclear. An industry may emerge that looks like Washington's; with a few large firms.

Changes in specific governmental policies in both states would impact directly the wine industry. A reduction in regulation (OLCC, WLCB, health and environment, land use) might open up more competition and reduce costs of production. This on the one hand might increase the industry size by attracting new firms, but on the other reduce the chances of land owners being forced into land uses and businesses they had never intended.

\footnotetext{
${ }^{210}$ Measure 5, a voter-initiated measure passed in November of 1990, reduces and limits future property taxes available for school and local government support in oregon. Measure 1 , which failed at the November 1993 election, would not only have created a sales tax but also diverted one-half of all lottery receipts to support schools.

${ }^{211}$ Not a concept opposed by all oregon wine makers. Through interviews, it was determined that some older wineries oppose Economic Development funds being used to assist the creation of new wineries; increased domestic competition in a limited market place can lessen market share for existing firms.
} 


\section{CONCLUSIONS}

This examination has been about two topics. Through the epistemology of a field-descriptive empirical study, measurements have been taken of three variables relevant to the growth of the number of a state's operating commercial wineries. Those variables are government intervention, presence or absence of an oligopoly, and the domestic state population's wine consumption.

The core research question has been, "is state government intervention in the wine industry correlated with the growth of a state's wine industry?" The answer has been "yes," with the correlation in Oregon being strong and in Washington being weak. This answer fits with the historical narrative of winery development in each state.

A secondary research question has been, "are the other variables correlated with the growth of a state's wine industry?" As for the presence of an oligopoly, in both states the correlation is too weak to be of any significance. With regard to the domestic state population's wine consumption, the correlation to the number of wineries in Washington is strong and in Oregon is weak.

The second topic has been about a way to look at how a state's policies interact. Is devising a measure of "net impact analysis" (based upon the cluster of relevant public agencies) a useful tool in examining how the world works? 


\section{The Literature}

The literature is not well developed in measuring state activities' impacts on specific industries. One early promising lead relating government activity to business activity was "political risk analysis."212 As a quantitative technique, it permitted an individual business to objectively evaluate whether a foreign market should be entered at a given time, based upon variables which included tax policy and governmental stability.

However, risk analysis was never developed to the regional or sub-national level from an industry standpoint. While still a promising field, the tools to apply in the situation described in this study do not exist. ${ }^{213}$

Only now, in the $1990^{\circ} \mathrm{s}$, is attention being turned toward evaluation of state economic development policies. ${ }^{214}$

${ }^{212}$ David B. Hertz and Howard Thomas, "Risk Analysis: Important New Tool for Business Planning," Journal of Business Strategy 3, 1983, pp. 23-29; Stefan H. Robock, "Political Risk: Identification and Assessment," Columbia Journal of World Business July-August 1971, pp. 6-20.

${ }^{213}$ In initial interviews, wine makers and winery owners were asked if they considered the risks involved in locating in either Oregon or Washington, based upon government policy. The answer was uniformly "no," in that the wine industry already assumes virtually all the risks of the marketplace agriculture, manufacturing, warehousing, wholesaling, transportation to market, and retailing. The risk of governmental policy change seemed very small to them at the time of their entry.

${ }^{214}$ Delysa Burnier, "State Economic Development Policy: A Decade of Activity," Public Administration Review 51, MarchApril 1991, pp. 171-175; Wilson, Op cit. 
The consensus is that while political dividends from such policies are paid immediately, it remains to be seen whether economic dividends will live up to their promises. ${ }^{215}$

For the most part, the literature focuses on economic development policy alone. It does not address clusters of policies that may interact one with another to produce something wholely unexpected. Without such a base, who could expect that land use policy, coupled with tax and agricultural policy, would force someone into starting a winery? Useful taxonomies of administrative agencies are also missing from the literature. While no regulatory agency has a $100 \%$ negative impact on the industry it regulates, 216 neither does a commodity commission nor a land-grant university have a 1008 positive impact. With a lack of any published data in the literature, one can be forced to rely upon the word of those directly impacted as in the survey embedded within this study.

With regard to the oregon and Washington wine literature, while it is abundant, it is not necessarily robust. Most published material is about specific wineries, and not the industry as a whole. Some material is prevented from

${ }^{215}$ Bernier, op cit., p. 175.

${ }^{216} \mathrm{Health}$ agencies, for example, help build reputations for products created under clean and controlled environments. 
being published because of confidentiality issues. 217

Another challenging aspect of searching the literature for data is the relative newness of this cycle of the wine industry. At least two interviewees indicated their belief that the number of wineries is a direct causal function of the number of vineyards which come into production in any given year. Yet there is little or no published data prior to 1985 from which an analysis could be made, nor any support in the literature for this belief.

Finally, while still considered a start-up industry, the literature demonstrates that wine and commercial wine making has been a part of Oregon and Washington history for at least 160 years. The industry has been cyclic, with the first cycle running from 1860 to 1913 , the second from 1933 to about 1955, and the current cycle begun in about 1970, continuing into the $1990^{\prime} \mathrm{s}$.

\section{Variables}

From interviews and a search of the literature, three variables were identified to explain the patterns of growth of this quasi-start-up industry. Directly related to market forces are an increasing demand for quality wine by consumers, government intervention as measured by expenditures and

${ }^{217}$ The US Department of Agriculture Statistical Service indicated they would oppose any Freedom of Information requests for winery financial and production detail, primarily due to confidentiality promises when the data is collected. 
intermittent market domination by a few large wineries.

These three variables, taken together, account for about 958 of the variability in industry size as measured by number of wineries in each state. Under a Beta analysis, there is at least one other unknown element at work.

Government managers cannot without extreme interference impact either the market consumption demand or market dominance. In the first instance, as with Prohibition, such efforts are most likely to be ineffective. In the second, adoption of antitrust style laws may also be ineffective and, as in the case of washington, counterproductive. What they can influence is the policy cluster that surrounds the issue. It appears that, to help "grow" an industry, the balance of policy spending must be increasingly positive. This may involve deemphasizing regulatory and restrictive policies, or emphasizing policies that provide assistive, direct and indirect service. It appears that it may be the balance, and the balance as perceived by those in the industry (to moderate friction or political infighting), of government involvement that is the important element.

Most firms will accept some degree of control, either as a necessary evil or perceiving that the public will trust a firm that is in compliance with regulations. On the other hand, there should also be some opportunity to acquire help when it is needed. 
CAUTIONS

In reviewing and accepting the data and results of this research, several cautions must be kept in mind as conclusions are evaluated. The time frame is relatively short, at 21 years. A longer-term sample may yield different results. Utilization of a mixed methodology, which includes interviews with wine makers and government officials, may introduce errors into the study impairing exact duplication of reșults. Memory shifts over time, and personal estimates were utilized to gauge governmental efforts in years when detailed budget figures were not available.

If the relationships between the independent variables and the dependent variable are not truly linear, then the statistical significance found herein may not reflect the real world. This is always a hazard in regression analysis, but if the variables are nonlinear with respect to one another, there may still be a high degree of interrelationship among them; at this point the matter is undetermined, and is a topic for further research.

No claims are made here for establishing causal effects. Government expenditures are expected to grow with increased numbers of wineries, as more inspectors and auditors are added to perform regulatory and redistributive functions, or increased sales generate more tax revenue to support research and commodity commission activities. 
Alternately, expenditures may taper off as tax reform measures limit state general fund expenditures. However, multiple regression with the data in this study lagged by one year, and cumulative over the time period, showed no significant differences over the within-year analyses.

Finally, as previously noted, the number of wineries says nothing about the relative individual winery firm sizes, and is not intended to draw any conclusions about which is more efficient or effective as a way to meet the demands of a market. Washington's five large wineries together far outproduce the sum total of all of Oregon's wineries, and those five wineries' gross receipts no doubt far outstrip the total Oregon gross receipts.

This study is not, however, about individual firm size, success or performance. It is about industrial and economic development fostered by programs initiated through state administrative policy processes, and carried out through the administrative policies and programs of many state agencies.

\section{RECOMMENDATIONS}

There are at least four recommendations that may serve to benefit both academic reviewers and practical practitioners of state-level economic development, and for those wishing to follow up on this particular study.

1: Collect, maintain, and publicize the existence of a data base, consisting both of numerical data and a body of 
literature, with relevant information about an industry under consideration for economic development aid.

Industry proponents will, of course, develop and publicize data they feel will aid in adoption of programs. objective data may not be maintained, and it may not include the negative aspects of a particular industry's operations, such as pollution, job displacement, or loss of tax revenue through application of farm credits or taxable status.

Government agencies will also collect data, but based upon a particular policy or narrow focus associated with the agency doing the collecting. While information gathered may be both positive or negative, it also may not be maintained. This leaves the academic community, which in the past has sometimes been loathe to collect practical data for application to either government or the business community. In an ever-increasing "information society," only through the creation and maintenance of a fair, complete and objective data base can informed decisions be made as to where resources should be committed.

Such data bases can also, in fiscally distressing times, be a source of revenue. Access to data bases need not be provided gratis, and this type of opportunity would seem tailor-made for universities of the 1990's.

2: Develop the concept of public policy cluster studies, and apply that concept to analyze an industry's chances of success before committing substantial dollars to 
its development.

It should be clear that no policy stands alone. No government entity, nor even government agency, is a monolith. There are differing personal opinions, laws, administrative rules, and policies within a single agency on a single topic, let alone an entire local or state government. Every new policy will be impacted by history, lawmakers, voters, special interests, and public administrators. Each policy carries whole or partial dormant or active sub-policies with it, and will help or hurt, facilitate or obstruct the development and implementation of still newer policies.

Courses of action, once set in motion, take on lives of their own. It seems only prudent to understand how those lives will impact a new course of action, and reasonable to assume that universities and policy analysis programs, with their intellectual resources, would be a key proponent of development of a holistic approach to their evolution.

3: Be willing to commit funds for evaluation of economic development activities, not only of short-term gains but also of long-term trends.

One comment by Burnier bears repeating: - . [state development policy] can bring immediate political dividends, but it may take years to produce the expected economic dividends. Development policy, then, stands at a critical juncture. will these approaches deliver the sustained economic growth envisioned by policy makers? Over the next decade, that critical question will be answered by how well the particular programs meet their 
ed by how well the particular programs meet their stated goals.

Policy makers want to be right in their choices. Not unlike a war where one side declares victory and pulls its support from its allies, there is a temptation to declare an economic victory and move on to the next issue.

If in the long run that economic element fails, perhaps the public's memory will be sufficiently short to avoid assignment of blame.

If public monies are to be spent wisely, then each program must contain within it the seeds of fair and equitable evaluation. Not all decisions are going to be the right ones, but if there is no mechanism in place to learn from mistakes then the same mistakes will be made again in the future.

A partnership between academia and government for program evaluation would not only provide government with a needed (if not welcomed) service, but could also provide universities with additional funding and a living laboratory for their students. If universities could propose legislation that required academic-run program evaluations, perhaps on a system that rotates among different colleges to share the financial resources, then all could benefit.

${ }^{218}$ Burnier, op cit., p. 175. 
4: Encourage replication of this or a similar study within the next decade, when additional data will be available, especially with regard to the impact of vineyard creation and production as a substantive variable in wine industry size.

This particular study's chosen design was perhaps the most complex and least controllable: a longitudinal timeseries, cross-subject comparison with no control group and no experimental treatment -- a "natural experiment." Some of the data, particularly the market domination variable and state agency budget components devoted to the wine industry, had to be constructed and estimated. Another investigator might have made different estimations based upon the available information and interviews.

The wine industry has been with the Northwest for a long time, and its apparent cyclic nature coupled with the rise of anti-alcohol sentiment among some, and cyclic correction of overexpansion, will surely lead to a downturn sometime in the future. Followed still later, one might expect, by an upturn.

Yet wine - much like government - has been with mankind for thousands of years, alternately hailed as a cure-all for physiological and psychological ills, and condemned as a paving stone on the roadway to Hell. As long as the vines will grow, and governments will make policy, there will be fertile ground for study. 
REFERENCES

Agricultural Research Foundation, Oregon State University. 1991. 1990-91 Wine Advisory Board Reports. Corvallis, OR: The Foundation.

Alroy, Odelia E. 1990. "Kosher Wine," Judaism: A Quarterly Journal. $39: 4,452-460$.

Anshen, Melvin and Francis D. Wormuth. 1954. Private Enterprise and Public Policy. New York: Macmillan.

Artlott, John. 1974. Wine. New York: Oxford University Press.

Asher, Gerald. 1982. On Wine. New York: Random House.

Avery, Mary W. 1973. Government in Washington state. Seattle, WA: University of Washington Press.

----. 1961. History and Government of the State of Washington. Seattle, WA: University of Seattle Press.

Baliscan, A. and J. Roumasset. 1983. "Policy Choice of Agricultural Policy: The Growth of Agricultural Protection," Quarterly Journal of Economics. 98: 371401 .

Barker, M. (Ed.). 1983. Financing State and Local Economic Development. Durham, NC: Duke University Press.

Barto, Harold E. and Catherine Bullard. 1953. History of the State of Washington. Boston: D.C. Heath. 2nd Edition.

Beadle, Dan J. 1979. "Wineries in Oregon," Oregon Herald. $1: 44,13$.

Beaumont, E. and H. Hovey. 1985. "State, Local, and Federal Economic Development Policies: New Federal Patterns, Chaos, or What?" Public Administration Review. 45:2, 327-332.

Berkeley, George E. 1978. The Craft of Public Administration. Boston, MA: Allyn \& Bacon, Inc., 2nd Edition. 
Berry, Jeffrey M. 1989. The Interest Group Society. Boston, MA: Little, Brown, and Co., 2nd Edition.

"Beyond Seattle: Grape Expectations - Complete Guide to 14 wineries," Seattle Weekly. June 20, 1990, B11.

Blalock, Hubert M. Jr. 1971. Causal Models in the Social Sciences. Chicago: Aldine, Atherton.

Blaylock, Joni. 1982. "So You Want to Start a Winery . . .," Oregon Business. $5: 8,51-56$.

Bourasaw, Noel V., Wine Almanac of the Pacific Northwest. Seattle, WA: The Author, irregular from 1983.

Brayton, Gary N. et al. 1989a. Second Annual Wine Industry Financial Survey. San Francisco, CA: Touche-Ross.

---- 1989b. Second Annual Wine Industry Financial Survey Participant Workshop. San Francisco, CA: Touche-Ross.

----. 1990. Third Annual wine Industry Financial survey. San Francisco, CA: Deloitte \& Touche.

Brenn, T. 1986. "The Troms Heart Study: Alcoholic Beverages and Coronary Risk Factors," Journal of Epidemiology and Community Health. $40: 3,249-256$.

"Brewers, Vintners Oppose Tax on Alcohol to Help Homeless," The Olympian. May 6, 1988, A7.

Bridges, Benjamin. 1965a. "State and Local Inducements for Industry, Part I, " National Tax Journal. 18: March, 114.

----. 1965b. "State and Local Inducements for Industry, Part II," National Tax Journal. 18: June, 175-192.

Browne, William P. 1988a. Private Interests, Public Policy, and American Agriculture. Lawrence, kS: University of Kansas Press.

Buerkin, K. 1984. The oregon wine Industry: Historical Perspectives and the Current production and Cost Situation. Corvallis, OR: Oregon State University Extension Service.

Bullard, Robyn. 1991. "Best Evidence Yet of Alcohol's Benefits," The wine Spectator. 16: 7 .

---. 1990a. "\$45,000 Raised for California School," The Wine Spectator. 15: 24. 
----, and Kim Marcus. 1991. "Debt Woes Hit Snoqualmie, Vintech Groups," The wine spectator. $x V: 18,9$.

Burnier, Delysa. 1991. "State Economic Development Policy: A Decade of Activity," Public Administration Review. $51: 2,171-175$.

Burns, James M. and Jack W. Peltason. 1963. Government by the People. Englewood Cliffs, NJ: Prentice-Hall. 5th Edition.

Burr, M.L. 1988. "A Tot a Day Keeps Disease Away," proceedings of the Nutrition Society. 47:2, 129-133.

California Legislature. 1937. California Marketing Act of 1937: Chapter 10, Division 6, California Agricultural Code. Sacramento, CA: The Legislature.

Castaldi, Mark A. 1984. An Investment Analysis of Small Premium Washington State Wineries. Yakima, WA: Washington State University.

---- 1985. Investment and Operating Costs for Various Winery sizes. Yakima, WA: Washington State University.

Casteel, Ted (Ed.). 1992. Oregon Winegrape Growers' Guide. Portland, OR: Oregon Winegrowers' Association, 4th Edition.

"Charles $W$. Nagel was Honored at Washington State University," Wines \& Vines. 1992. 73:7, 8.

Chase, Corraine. 1986. "Susan Sokol Blosser Pioneers Wine Wines," Northwest Women. 2:1, 50-51.

"Chateau Ste. Michelle Workers Urge National Boycott of Winery," The Oregonian. September 8, 1992, C7.

Clark, D. Corbet. 1989. American Wines of the Northwest: A Guide to the wines of Oregon, Washington and Idaho. New York: W. Morrow.

----, and Lynn Crook. 1984. Great Grapes: A Guide to the Wines and Wineries of Washington. Tacoma, WA: Heath Communications.

Clore, W.J. 1974. "An Update on Washington State," Wines \& Vines. $55: 12,34-35$.

Colton, Charles (Ed.). 1965. State and Local Taxes on Business. Princeton, NJ: Tax Institute of America. 
Columbia Region Association of Governments. 1974. ColumbiaWillamette Region Comprehensive Plan: Discussion Draft. Portland, OR: The Association.

-- 1975. CRAG Overview: Data for the Planning Process. Portland, OR: The Association.

Columbia Wines. N.d. Columbia: Pioneers in Washington state Premium Wines. Bellevue, WA: Columbia Wines.

Connolly, Suzette L. 1984. Geography of the Northwest wine Industry. Seattle, WA: University of Washington.

Cox, George H. et al. 1991. "Local Government Support for Economic Development," Public Administration Quarterly. $15: 3,304-327$.

Cross, Tim and Ted Casteel. 1989. Vineyard Economics: The Costs of Establishing and Producing wine Grapes in the Willamette Valley. Corvallis, OR: Oregon State Extension Service, Report EM 8407.

Daneke, Gregory. 1985. "Small Business Policy Amid State Level Economic Development Planning," Policy Studies Journal. 13, 722-728.

Dauer, Christopher. 1991. "Chubb Uncorks Wine Insurance Program," National Underwriter (Property/Casualty/ Employee Benefits). 95:47, 17-18.

De Wolk, Roland. 1989. "Red Wines may Fight Cancer," The Wine Spectator. $14: 7$.

"'Deadly Weapon' Cited," The Oregonian. November 3, 1989, B4.

Delacroix, Jacques and Anand Swaminathan. 1991. "Cosmetic, Speculative, and Adaptive Organizational Change in the wine Industry: A Longitudinal Study," Administrative Science Quarterly. 36:4, 631-661.

Denne, Lorianne. 1989a. "Cascade Cellars Uncorks \$1 Million Stock Sale," Puget Sound Business Journal. 9:4, 3 .

---- 1989b. "Stock Sale by Cascade Estates Winery Goes Slowly," Puget sound Business Journal. 10:17, 5.

Dimock, Marshall E. and Gladys O. Dimock. 1964. Public Administration. New York: Holt, Reinhart and Winston, Inc. 3rd Edition. 
Dolnick, Edward. 1990. "Le Paradoxe Francais: How do the French Eat All that Rich Food and Skip the Heart Disease?" In Health. 4: 40-47.

Domaine Drouhin Oregon. 1988. Application for Oregon Economic Development Revenue Bonds. Dundee, OR: Domaine Drouhin Oregon.

Dornbusch, David M. \& Company, Inc. 1991. Tourist Oriented Directional signs. Washington, D.C.: U.S. Department of Agriculture.

----, and Claudia J. Kawczynska. 1992. "Tourist Oriented Directional Signs: A Self-Supporting Program to Promote Rural Business and Economic Development," Journal of Travel Research. 31:1, 3-9.

"Dream Dies on the Vine: Haviland's Demise; It's Eyes Bigger than Wallet," Seattle Post-Intelligencer. June 11, 1988 , B3.

Duff, Dan. 1985. "Oregon Wine-Makers Write Labeling Laws for Own Benefit," The oregonian. July 30, FD6.

EcoTours of Oregon. 1992. Three Oregon Experiences. Portland, OR: EcoTours of Oregon.

"\$85,000 Raised for Monastery," The Wine Spectator. 15: June $15,1990,13$.

Eisinger, Peter K. 1988. The Rise of the Entrepreneurial State. Madison, WI: University of Wisconsin Press.

Ellis, Walter G. 1977. Typology of Administrative Organizations. Portland, OR: Portland State University. Mimeo.

Ensrud, Barbara. "Beaver State's Wine Boom," Wall Street Journal. October 19, 1988, A-12.

Epitope, Inc. 1992. Annual Report - 1992. Beaverton, OR: Epitope, Inc.

---- 1992. Securities and Exchange Commission Form 10-K. Beaverton, OR: Epitope, Inc.

Fadiman, Clifton and Sam Aaron. 1975. The Joys of Wine. New York, NY: Harry N. Abrams, Inc.

Faith, Nicholas. 1978. The Winemasters. New York: Simon \& Schuster. 
Ferrence, R.G. et al. 1986. "Drinking and the Prevention of Coronary Heart Disease: Findings, Issues and Public Health Policy," Journal of Studies on Alcohol. 47:5, 394-408.

Finlayson, Gail. 1989. "Scientist says Red wine can Fight Cancer," Wines \& Vines. 70:7, 42-43.

"First Winery Operates: Lois Herbolt Leading Way in Oregon," The Sunday Oregonian. May 27, 1934, B2.

Fisher, Chris et al. 1986. Market Research Survey of Consumers and Retailers/Restaurateurs. Eugene, OR: University of Oregon.

Folwell, Raymond J. 1985. Implications of International and National Trends on the washington Wine Industry. Yakima, WA: Washington State University.

-.--, and John I. Baritelle. 1978. The U.S. Wine Market. Washington, D.C.: U.S. Department of Agriculture Economics, Statistics and Cooperatives Service.

--- , and Mark A. Castaldi. 1987. "Economics of Size in Wineries and Impacts of Pricing and Product Mix Decisions," Agribusiness. 3: $28+$.

Francis, A.D. 1972. The Wine Trade. London, ENG: Adam and Charles Black.

Fuller, William and Virginia Fuller. Tualatin Notes. Forest Grove, OR: Tualatin Vineyards, irregular.

Gardner, B.I. 1987. The Economics of Agricultural Policies. New York: Macmillan.

Gayot, Andre. 1993. Guide to the Best Wineries of North America. Los Angeles, CA: American Automobile Association.

Goldberg, Howard G. 1991. "Washington Winery Wants a "Pacific Coast" Appellation," The New York Times. 140: June $26, B 5+$.

Goldfield, Robert. 1991. "Oregon Winemakers See Tourism as the Main Ingredient in Future Sales," Daily Journal of Commerce. August 9, 1991, 3, 32 .

Gray, D. et al. (Eds.). 1986. Technological Innovations: Strategies for a New Partnership. Amsterdam: North Holland. 
Greenwald, Douglas (Ed.). The McGraw-Hill Dictionary of Modern Economics. New York: McGraw-Hill, 1965. 3rd Edition.

Gurr, Ted Robert. 1972. Politimetrics: An Introduction of ouantitative Analysis. Englewood Cliffs, NJ: PrenticeHall.

Hagood, Pat. 1974. "Washington State Grape Society Cautions on 2-4D, Grape Boycotts," Wines \& Vines. 55:2, 50.

----. 1977. "Washington's Nagel Recommends Growers Plant Nine Vitis Vinifera Grapes," Wines \& Vines. 58:7, 27.

Hailstones, Thomas J. 1984. Basic Economics. Cincinnati: South-West Publishing Company.

Hamm, Keith E. 1983. "Patterns of Influence among Committees, Agencies and Interest Groups, "Legislative Studies Quarterly. 8:8, 379-426.

Hanlon, S.B. 1986. "Disheartened Winery Representatives Say Packwood's Excise Tax would Crush the Industry," Tax Notes. 31: April 14, 109-110.

Hawksworth, M.E. 1988. Theoretical Issues in Policy Analysis. Albany, NY: State University of New York at Albany.

Haworth, Lauren. 1992. "Top 25 Oregon Wineries," Business Journal-Portland. $9: 16,10$.

Hellman, Daryl et al. 1976. State Financial Incentives to Industry. Lexington, MA: Lexington Books.

Hertz, David B. and Howard Thomas. 1983. "Risk Analysis: Important New Tool for Business Planning, "Journal of Business strategy. 3: 23-29.

Hiaring, Philip E. 1972. "The Evergreen State: 'We're Going to be Number $2^{\prime}$," wines \& Vines. $53: 4,31-33$.

---. 1992. "Financial Symposium Puts the Lie to Many 'Verities of the '80s'," Wines \& Vines. 73:11, 53-54.

Hill, Gail Kinsey. 1993a. "Legislators Forced to Mull Wine Tax Law," The Oregonian. January 27, B4.

- 1993b. "Roberts Sees Sin Taxes as Best Hope," The oregonian. January $24, \mathrm{C} 4$. 
Hill, Jim. 1992. "Sake Comes to Oregon; kanpai (Cheers)," The Oregonian. September 15, C7.

Holden, R. 1989. Northwest Wine Country: Washington, Oregon, Idaho. Seattle, WA: Holden Pacific.

Holland, Stuart (Ed.). 1972. The State as Entrepreneur. London, ENG: Weidenfeld and Nicolson.

Holmgren, Elisabeth. "Health Issues," Wines \& Vines. $72: 4$, $34 ; 72: 6,15 ; 73: 2,5-7 ; 73: 4,13 ; 73: 6,51-52 ; 73: 10$, $26 ; 73: 11,49$.

Hunt, Linda. 1982. Alcohol Related Problems. London: Heinemann Educational Books.

Hutchison, John. 1976. "Ste. Michelle Brings a Chateau winery to Rural Woodinville," Wines \& Vines. 57:10, 26.

"In Vino Paupertas," Fortune. 117: April 25, 1988, 12.

Irvine, Ron. 1993a. "Planting Dreams: Washington State's Wine Roots," The Northwest Palate. 6:6, 26-27+

----. 1993b. "Planting Dreams: Washington State's Wine Roots, Part II," The Northwest Palate. 7:1, 38-39+.

Jacobs, Julius. 1986. "Physicians Talk about the Health Value of Wine," Wines \& Vines. 67:6.

Jalonen, Wendy. 1987. "Local Graphic Design Toast," Puget Sound Business Journal. June 29, B6.

---. 1985a. "Oregon Wine Industry Blitzes Washington Market," Puget Sound Business Journal. October 7, A3.

----. 1986a. "Ste. Michelle Winery Uncorks Sweet Taste of Profitability," Puget Sound Business Journal. November 24, A2.

----. 1986b. "Snoqualmie Buys Langguth Winery to Become Second Biggest in State," Puget Sound Business Journal. November $24, \mathrm{~A} 10$.

----. 1985b. "Two Veteran Vintners Start State Wine Marketing Firm," Puget Sound Business Journal. May 20, A13.

---. 1985c. "Wine Industry Growing Economic Muscle," Puget Sound Business Journal. June $3, \mathrm{Al}$. 
Jodice, David A. 1985. Political Risk Assessment: An Annotated Bibliography. Westport, CT: Greenwood Press.

Johnson, Hugh. 1977. The World Atlas of wine. New York: Simon and Schuster. Revised Edition.

Jones, Charles 0.1970. An Introduction to the Study of Public Policy. Belmont, CA: Wadsworth Publishing.

Joy, Henry and Thomas W. Phillips. 1929. Scandals of Prohibition Enforcement. Detroit, MI: The Authors.

Kadera, Jim. 1993. "Oregon Agricultural Interests Expand Right-to-Farm Concept," The Oregonian. February 24, B2 .

----. 1990a. "Packwood Still Pushing for winery Tax Exemption," The Oregonian. October 16.

----. 1991. "Two Leading Oregon Wineries Form Alliance," The sunday Oregonian. July 28, P3.

--- . 1990b. "Vineyard Launches 2nd Stock offering," The Oregonian. July $16, \mathrm{D} 8$.

Kaplan, D.R. 1986. "A Novel Mechanism of Immunosuppression Mediated by Ethanol," Cellular Immunology. 102:1, 1-9.

Koberstein, Paul. 1992. "Betrayal, Bureaucracy and Bungling," The Sunday Oregonian. October 25, D1, 10 .

Kobrin, stephen J. 1982. Managing Political Risk Assessment. Berkeley, CA: University of California Press.

Koontz, Harold D. 1941. Government Control of Business. Boston, MA: Houghton Mifflin.

Kramer, Matt. 1986. "Bureaucrats Cloud Wine Hassle Truth," The Oregonian. May 9, C1.

----. 1987a. "Drouhin Investment Gives Oregon a Prized French Connection," The Oregonian. September 11, D3.

---- 1987b. "Wine Bill a Mistake for Industry," The oregonian. March 20, 1987, El.

Kyvig, David E. 1979. Repealing National Prohibition. Chicago, IL: University of Chicago Press.

"Large State Winemaker Files Chapter 11 Petition," The olympian. December 12, 1990, B6. 
Lepawsky, Albert. 1949. State Planning and Economic Development in the South. Washington, D.C.: National Planning Association.

Liston, Linda. 1967. "States Spar in Sizzling Contest for Industry," Industrial Development and Manufacturers Board. $136: 6,22-28$.

Loubere, Leo A. 1990. The wine Revolution in France. Princeton, NJ: Princeton University Press.

Loveridge, Scott and Thomas R. Smith. 1992. "Fostering Relationships between Local Government and Rural Businesses," Public Productivity \& Management Review. $15: 3,329-340$.

Lowi, Theodore. 1969. "The Public Philosophy: Interest-Group Iiberalism," in Edward V. Schneier (Ed.). Policy-Making in American Government. New York: Basic Books.

Lund, Leonard. 1976. Business/Government Partnership in Local Economic Development Planning. New York: Conference Board.

Mackenzie, Bill. 1987. "French Winery will Make Oregon Stomping Ground," The Oregonian. September 4, C10.

Major, Michael J. 1993. "The Columbia Crest Approach to Demystifying Wine," Wines \& Vines. 74:8, August, 19$21+$.

----. 1989a. "Legal Threat Silences Industry (Fetal Alcohol)," Wines \& Vines. $70: 4,16-21$.

-.--. 1989b. "To Market, to Market . . ." Wines \& Vines. $70: 8,18-22$.

Malecki, Edward. 1984. "High Technology and Local Economic Development," Journal of the American Planning Association. 50: Summer, 262-269.

March, J.G. and H.A. Simon. 1958. Organizations. New York: Wiley. Especially Chapter 3, 36-47.

Marton, Keith. 1990a. "How Doctors Could Deal with the Drys," Wines \& Vines. 71:6, 64-67.

--- 1990b. "The Impact of Moderate Use," Wines \& Vines. $71: 1,14$. 
Matthews, Thomas. 1990a. "Million-Dollar Weekend for wine in Chicago . . .," The Wine spectator. 14: March 31, 1617 .

----. 1991. "New York's Grandest Charity Wine Auction," The wine Spectator. 16: December 15, 16 .

--- . 1990b. "Wine Auctions Lucrative for Public TV," The Wine Spectator. 15: June 15, 13.

McCann, Lluana. 1989. Oregon Policy Choices 1989. Eugene, OR: Bureau of Governmental Research and Service, University of Oregon.

McKenzie, Richard. 1984. Fugitive Industry: The Economics and Politics of Deindustrialization. San Francisco: Pacific Institute.

McMillan, Dan. 1992a. "Oregon Winery Basks in National Investment Spotlight," Daily Journa. of Commerce. May 13,3 .

----. 1992b. "Winery Gets Ready for Expansion," Daily Journal of Commerce. August 17, 3 .

"Menus \& Venues: Shoddy Spirits Bring Death Sentence," The Oregonian. March 10, 1993, D6.

Micallef, J.V. 1981. "Political Risk Assessment," Columbia Journal of World Business. September, 47-52.

Miles, Stanley. 1989. Oregon Agricultural Commodities: Farm Values and Processed Values. Corvallis, OR: Oregon State Extension Service. Special Report 533, Revised.

----, and A. Gene Nelson. 1985. Trends in Oregon Farmland Value. Corvallis, OR: Oregon State Extension Service. Report FS 268, Revised.

Mills, John. 1984. "HillCrest Vineyards: An LCDC Tale of Woe," Landmark. 1:4, 24-25.

Mokwa, Michael P. and Steven P. Permut (Eds.). Government Marketing: Theory and Practice. New York, NY: Praeger, 1981 .

Momokawa Sake, Ltd. 1992. Connoisseur's Guide to Premium Sake. Forest Grove, OR: Momokawa Sake, Ltd.

Moraine, Claudia. 1992. "Grape Growers' Wrath," American Medical News. 35:24, 45-49. 
Mullen, w. Frank et al. 1978. The Government and Politics of Washington State. Pullman, WA: Washington State University Press.

Narver, B. et al. 1990. Washington Policy Choices: 1990s. Seattle, WA: University of Washington Institute for Public Policy and Management.

Nelson, Biil. 1990. "Reflections on Passage of an Important Decade," OWA Regular Membership Newsletter. 2:1, 1-2.

Nice, David C. et al. (Eds). 1992. Government and Politics in the Evergreen State. Puliman, WA: Washington State University.

Nigro, Felix A. 1970. Modern Public Administration. New York: Harper \& Row. 2nd Edition.

North, Douglass. 1955. "Location Theory and Regional Economic Growth," The journal of Political Economy. 63 : June, 234-258.

Ochs, Ridgely. "What's a Woman to Do?" The Oregonian. May 24, 1993, p. C3.

Ogden, Daniel M. 1989. How National Policy is Made. Portland, OR: The Author.

Oregon Chapter, American Cancer Society. 1986, 1987. Annual American Cancer Society wine Tasting. Portland and Eugene, OR: American Cancer Society. Event booklet.

Oregon Department of Agriculture, Agricultural Statistics Service. 1989. 1988-89 Oregon Agricultural and Fisheries Statistics. Salem, OR: The Department.

Oregon Department of Human Resources, Office of Alcohol and Drug Abuse Programs. 1990. Operations Plan, FY 1991: Section IV, Appendix B, Substance Abuse and Early Rrevention. Salem, OR: The Office.

Oregon Economic Development Department. 1990. Doing Business in Oregon. Salem, OR: The Department.

----- 1991. Economic Development Revenue Bond Program: Program Description and Information for Applicants. Salem, OR: The Department.

-.-. 1991. Oregon Business Development Fund: List of Approved Projects. Salem, OR: The Department. 
--- 1990. Oregon Business Development Fund: Program Description and Pre-Application. Salem, OR: The Department.

Oregon Executive Department. Adopted Budget, Biannual Legislative Assembly. Salem, OR: Oregon Executive Department, one year after biennium.

----. Governor's Recommended Budget. Salem, OR: Oregon Executive Department, one year before biennium.

----. Oregon Comprehensive Annual Financial Report. Salem, OR: Oregon Executive Department, annually.

Oregon Health Division, Department of Human Resources. 1992. Alcohol and Drugs in oregon, 1989. Portland, OR: Oregon Health Division.

---: 1991. Health objectives for the Year 2000. Portland, OR: Oregon Health Division.

---. 1990. Reducing Risk Behaviors that Affect Health. Portland, OR: Oregon Health Division.

Oregon Land Conservation and Development Commission. 1991. Farm and Forest Research Study: Discussion of Policy Issues: Task I, II, and III Reports. Salem, OR: The Commission.

--. 1990. Oregon's Statewide Planning Goals: 1990. Salem, OR: The Commission.

Oregon Land Conservation and Development Department. 1991. Shaping Oregon's Future: Biennial Report for 19891991. Salem, OR: The Department.

Oregon Legislative Assembly. Oregon Revised Statutes Chapters 377, 471, 473, 576. Salem, OR: The Assembly.

Oregon Liquor Control Commission. 1987. Law Excerpts from Manufacturers and Wholesale Distributors of Alcoholic Liquor. Portland, OR: The Commission.

---. OLCC Administrative Rules, Chapter 845. Portland, OR: The Commission.

----. N.d. Qur Values. Portland, OR: The Commission.

----. Winery Statistical Summaries. Portland, OR: The Commission, annually from 1987. 
Oregon Lottery Commission. 1993. Willamette Valley Vineyards: Advertising Spot for Oregon Lottery commission. Salem, OR: The Commission.

Oregon Progress Board. 1992. Oregon Benchmarks. Salem, OR: The Board.

Oregon Secretary of State. Oregon Blue Book. Salem, OR: Secretary of State's office, biannual publication.

Oregon Travel Information Council. 1991. Travel Oriented Directional signing \& Fee schedule. Salem, OR: The Council.

Oregon Vineyard Tours. 1984. Oregon's Vineyard Tours. Portland, OR: Oregon Vineyard Tours, Inc.

Oregon Wine Advisory Board. 1992. FY 92-93 WAB Marketing Plan. Portland, OR: The Board.

----. Minutes of Monthly Meetings. Portland, OR: The Board, irregular.

----. 1993. Oregon Winery List. Portland, OR: The Board.

---. 1984. Oregon Wines... They Could Only Happen Here. Portland, OR: The Delkin Company.

---- 1985. Oregon Wine Industry Facts. Salem, OR: The Board.

----, Research Committee. WAB Cellar \& Vineyard Notes. Portland, OR: The Board, irregular.

Oregon Wine Advisory Board and Oregon Department of Agriculture. Wine Advisory Board Research Report. Portland, OR: The Board and the Department, irregular.

Oregon Wine Advisory Board, Washington Wine Commission and Thriftway Grocers. 1992. Pacific Northwest Appellations Map. Salem, OR: Wine Advisory Board.

Oregon Wine Press. Oregon Wine. Portland, OR: Oregon Wine Press, monthly except December-January from 1984.

Oregon Winegrowers' Association. Discover Oregon Wineries. Salem, OR: Pending Formations, annually or biannually from 1981 .

--- 1991. 1991 Membership Directory and Reference Guide. Portland, OR: Oregon Winegrowers' Association. 
----, Southern Oregon Chapter. N.d. Wineries of Oregon's South Willamette Valley. Eugene, OR: The Chapter.

"Pacific Northwest Wine: Growing Industry," Portland Magazine. September 1976, 15.

Pack, Janet. 1973. "Determinants of Migration to Central Cities," Journal of Regional Science. 13: August, 249260 .

Peirce, Neal R. "Wars between States Waste Coveted Money," The Oregonian. April 19, 1993, p. B7.

Perdue, Lewis. 1992. The French Paradox and Beyond. Sonoma, CA: Renaissance Publishing, 1992.

Perry, D. and A. Watkins (Eds.). 1977. The Rise of the Sunbelt Cities. Beverly Hills, CA: Sage.

Peterson-Nedry, J. 1992. "The Church of Royal and Other Spokane Tales," The Northwest Palate. SeptemberOctober, 24-27.

-.-. 1991. "Domaine Drouhin Oregon . . .," The Northwest Palate. May-June, 23-24t.

----. 1989. "Laurent-Perrier Buys Oregon Land," The wine Spectator. 14: August 31, 15.

Plosila, Walter and David Allen. 1985. "Small Business Incubators and Public Policy: Implications for State and Local Development Strategies," Policy Studies Journal. 13: June, 729-734.

Potticary, John F. 1968. Potential for the Development of a Wine and Supporting Wine Grape Industry in Oregon. Salem, OR: Oregon Department of Commerce, Economic Development Division, August.

Premus, Robert. 1982. Location of High Technology Firms and Regional Economic Development. Washington, D.C.: Subcomittee on Monetary and Fiscal Policy, Joint Economic Committee, U.S. Congress.

Prestwich, Patricia. 1988. Drink and the Politics of Reform. Palo Alto, CA: Society for the Promotion of science and Scholarship, Inc.

Price Waterhouse. 1991. Report of Independent Accountants to the Board of Directors and Shareholders of Willamette Valley Vineyards, Inc. Portland, OR: Price Waterhouse. 
"Professor Porter Lombard has Retired from Oregon State Horticulture," Wines \& Vines. 73:7, July 1992, 8.

Purser, J. Elizabeth and Lawrence J. Allen. 1977. The Winemakers of the Pacific Northwest. Vashon Island, WA: Harbor House Publishing Ltd.

Rabin, Robert L. 1979. Perspectives on the Administrative process. Boston, MA: Little, Brown and Company.

Rasky, Susan F. 1990. "Some Firms will Get Tax Breaks," The oregonian. October 22, A7.

Reiten, Richard G. 1988. Memorandum: Application of Domaine Drouhin Oregon, Inc. for Industrial Development Revenue Bond Financing, to be considered at the Finance Committee's June 22, 1988 Meeting. Salem, OR: Director, Oregon Economic Development Department, June 15.

Richardson, Harry. 1973. Regional Growth Theory. London: Macmillan.

Roberts, Barbara. 1993. Speech of the Oregon Governor before the West Iinn (OR) Chamber of Commerce. West Linn: April 27.

Robock, Stefan H. 1971. "Political Risk: Identification and Assessment," Columbia Journal of World Business. JulyAugust, 6-20.

Rogers, Jerry (Ed.). 1983. Global Risk Assessments: Issues, Concepts \& Applications. Riverside, CA: Global Risk Assessments, Inc.

Rosemary, Kristine. "Wine Boycott Seeks Bargaining Rights," The Oregonian. September 21, 1993, B7.

Samuelson, Paul A. 1964. Economics: An Introductory Analysis. New York, NY: McGraw-Hill. 6th Edition.

Schneider, Edward V. (Ed.). 1969. Policy-Making in American Government. New York: Basic Books.

Schnoor, Bryan D. 1979. Research, Analysis and Program for Levey Vineyards Winery. Pasco, WA: N.P.

Shaffer, Leslie and Paul Appelt. 1969. "Wine Grapes - Possible New Crop for Oregon," Oregon Farmer. August 7, $6+$. 
Shapiro, Alan C. 1981. "Managing Political Risk: A Policy Approach," Columbia Journal of World Business. 16:3, 63-70.

Shoemaker, Wells. 1990. "How Researchers 'Sold' the Fetal Alcohol Syndrome," Wines \& Vines. $71: 4,16-19$.

Simmons, Robert H. and Eugene P. Dvorin. 1977. Public Administration: Values, Policy, and Change. Port Washington, NY: Alfred Publishing.

Simon, Herbert A. 1976. Administrative Behavior. New York: Free Press. 3rd Edition.

Simons, Henry C. 1948. Economic Policy for a Free Society. Chicago, IL: University of Chicago Press.

Smith, Robert. 1982. "Wine and Washington," The Liquor Reporter. April, 8-9.

"Snoqualmie Quaffs Langguth Winery," The Liquor Reporter. January $1,1987,1+$.

Sogge, Bob. 1982. "A History of Oregon Wines," Lane County Living. October, 6-7.

Sokol Blosser, Susan. 1992. "History and Character of the Oregon Wine Industry," in Casteel, Ted (Ed.). Oregon Winegrape Growers' Guide. Portland, OR: Oregon Winegrowers' Association, 1-3.

----. 1991. Speech before the Portland State University Business Department Alumni Association, Portland, OR. November 2 .

"State-by-State Distributor Guide," Wines \& Spirits. 11:6, $1992,40-44$.

"Staying Liquid," The Economist. 309: November 26, 1988, 91.

Steinbach, Carol and Robert Guskind. 1984. "High-Risk Ventures Strike Gold with State Government Financing, " National Journal. 16: September 22, 1767-1771.

Steiner, George A. 1953. Government's Role in Economic Life. New York: McGraw-Hill.

Steinnes, Donald. 1984. "Business Climate, Tax Incentives, and Regional Economic Development," Growth and Change. 15: April, 38-47. 
Stockley, Tom. 1977. Winery Trails of the Pacific Northwest. Mercer Island, WA: Writing Works.

----. 1978. Winery Tours in Oregon, Washington, Idaho and British Columbia. Seattle, WA: Writing Works.

Strance, W.E. 1986. Alcohol Hospitality for the Eighties and Nineties. Oregon City, OR: The Author. Prepared for the Oregon Liquor Control Commission.

Strange, Carolyn. 1991. "Biotechnology in the Vineyard," Vineyard \& Winery Management. September/October. Reprint.

Tharpe, Mike and Ann Moncreiff. 1990. "America's 'Little Dragons': Why Six States are Prospering Amid the Nation's Malaise," US News and World Report. 109:5, 19.

Thomas, William. 1975. Historical and Functional Aspects of State Industrial Development organizations. Columbia, SC: University of South Carolina.

Thompson, E. Jr. 1980. Farming in the shadows of suburbia. Washington, D.C.: National Association of Counties Research Foundation.

Ting, Wenlee. 1988. Multinational Risk Assessment and Management: Strategies for Investment and Marketing Decisions. New York: Quorum Books.

Toner, W. 1978. Saving Farms and Farmlands: A Community Guide. Chicago: American Society of Planning Officials, Report No. 333.

"Transcript: Sixty Minutes: The French Paradox," Sixty Minutes. New York: CBS, November 1991.

Tripp, Julie. 1989. "Winery Suspended for Not Disclosing sulfite Content," The Oregonian. December 22, F10.

Tualatin Vineyards. The Story of Tualatin Vineyards. Forest Grove, OR: Tualatin Vineyards, annually from 1985.

" $\$ 20,000$ Raised in Phoenix Theater Benefit," The Wine Spectator. 15: May 15, 1990, 15.

United Oregon Horticulture Advisory Board. 1987. Oregon's Growing Industry: A Profile of High-Value Crops. Corvaliis, OR: Oregon State University Department of Horticulture. 
U.S. Congress. 1966a. Demonstration Cities and Metropolitan Development Act of 1966. Washington, D.C.: U.'S. Government Printing office.

U.S. Congress. 1966b. Housing and Urban Development Act of 1966. Washington, D.C.: U.S. Government Printing Office.

U.S. Congressional Budget Office. 1984. The Federal Role in State Development Programs. Washington, D.C.: U.S. Government Printing Office.

U.S. Department of Agriculture. 1988. Oregon Vineyard and Winery Report, 1987. Portland, OR: USDA Agriculture Statistics Service.

----. Oregon Vineyard Report. Portland, OR: USDA Agricultural statistics Service, annually from 1988.

----. Oregon Winery Report. Portland, OR: USDA Agricultural Statistics Service, annually from 1988.

----. Washington Agricultural Statistics. Seattle, WA: USDA Agricultural Service, annually.

U.S. Department of Commerce, Census Bureau. 1984. 1982 Census of Agriculture; Part 37, Oregon state and County Data. Washington, D.C.: U.S. Government Printing Office.

---. 1971-1991. Census of Population. Washington, D.C.: U.S. Government Printing Office.

---. 1989. County and City Data Book, 1988. Washington, D.C.: U.S. Government Printing Office.

----. 1991. State and Metropolitan Area Data Book. Washington, D.C.: U.S. Government Printing Office.

----. 1992. Statistical Abstract of the United States 1992. Washington, D.C.: U.S. Government Printing Office.

U.S. Department of Health and Human Services. 1990. Healthy People: 2000. Washington, D.C.: U.S. Government Printing Office. Chapter 4, "Alcohol and Other Drugs," 163-184.

U.S. Department of Housing and Urban Development. 1979. Urban Development Action Grant Program: First Annual Report. Washington, D.C.: U.S. Government Printing Office. 
U.S. Department of the Treasury, Bureau of Alcohol, Tobacco and Firearms. 1985. Information for New wineries. Washington, D.C.: BATF.

U.S. House of Representatives. 1985. Federal and State Roles in Economic Development. Hearings. 99th Congress, 1 st Session; Washington, D.C.: U.S. Government Printing Office.

U.S. Small Business Administration. 1984a. State Export Promotion Activities. Washington, D.C.: U.S. Government Printing office.

---- 1984b. State Policies and Programs to Enhance the Small Business Climate. Washington, D.C.: U.S. Government Printing Office.

---. 1979. The states and Small Business. Washington, D.C.: U.S. Government Printing Office.

Valette, Jean-Michel G. 1990. Dollars Vs. Gallons: Time for a Change of Perspective. San Francisco, CA: Hambrecht \& Quist, Inc.

--- 1987. U.S. Wine Industry: Emerging Opportunities. San Francisco, CA: Hambrecht \& Quist, Inc.

"Vintner Leaves in Protest," The Oregonian. October 15, 1990, B3.

"Vineyards: Fertile Ground for Sightseers: [PNW] Region's Wineries are Becoming a Key Industry," Travel Weekly. $49: 10$, February 1, 1990, 20.

Walker, Larry. 1985. "Iila Gault Focuses on the Wines of Washington State," Wines \& Vines. $66: 11,80$.

Walker, Lee. 1989. The Changing Arena: State Strategic Economic Development. Washington, D.C.: Council of State Governments. Vol. 2 .

Washington Constitution. Olympia, WA: State of Washington, 1889 .

Washington Legislature. 1987. Revised Code of washington, Annotated, Chapter 15.88. Olympia, WA: The Legislature. Laws 1987, Chapter 452 .

----. Revised Code of Washington, Annotated, Chapter 66.24. Olympia, WA: The Legislature, 1937 et seq. 
Washington State Department of Agriculture. 1985. Washington State Wine News. Olympia, WA: The Department.

Washington State Department of Commerce. 1983. Washington State Wineries. Olympia, WA: The Department.

Washington State Department of Commerce and Economic Development. 1961. The Grape Industry in the state of Washington. Olympia, WA: The Department.

Washington State Liquor Control Board. 1991. Liquor Laws and Regulations. Olympia, WA: The Board, with changes.

---. Report of Net Wine Sales to Importers and Wholesalers in the State of Washington. Olympia, WA: The Board, monthly.

----. Report of Ouantity of wine sold to Importers and Wholesalers within the state of Washington, stated in Gallons. Olympia, WA: The Board, monthly.

Washington State University, College of Agriculture. 1974. Economic Development Impact of an Expanded Wine-Grape Industry in Washington. Yakima, WA: The College.

---. 1975. Technical and Economic Assistance in Fostering the Economic Development of the Wine-Grape Industry in Washington. Yakima, WA: The College.

---. 1973. "Washington's Wine Future:" Proceedings of a Seminar for the Pacific Northwest Grape and Wine Industry. Yakima, WA: Washington State Department of Commerce and Economic Development, November 7-8.

Washington Wine Commission. 1989a. Growth Continues for Washington Wine Grape Acreage. Seattle, WA: The Commission.

---. 1993. Touring the Washington wine Country. Seattle, WA: The Commission.

----. N.d. Wine Commission Created by Washington State Legislature. Seattle, WA: The Commission, n.d.

Webster's Editorial Board. 1967. Webster's Seventh New Collegiate Dictionary. Springfield, MA: Merriam.

Welch, Susan and John Comer. 1988. Quantitative Methods for Public Administration. Chicago, IL: Dorsey Press.

Wheat, Leonard. 1983. Regional Growth and Industrial Location. Lexington, MA: Lexington Books. 
White, Anthony G. 1990. Eruits of the Vine: Oregon's Government and Wine Industry Toward the Year 2000. Portland, OR: Lewis \& Clark College, unpublished paper.

---- (Ed.). Northwest Wine \& Dine. West Linn, OR: Northwest Wine \& Dine, Inc., bimonthly 1985-1987.

Wilcox, Clair. 1955. Public Policies Toward Business. Homewood, IL: Richard D. Irwin, Inc.

Wildavsky, Aaron. 1974. The Politics of the Budgetary. Process. Boston: Little, Brown and Company.

Wilford, John N. 1991. "The Earliest Wine: Vintage 3500 B.C. and Quite Robust," The New York Times. 140: April 30, $\mathrm{B} 1+$.

Wilson, James Q. (Ed.). 1966. Urban Renewal: The Record and the Controversy. Cambridge, MA: MIT Press.

Wilson, Roger. 1989. State Business Incentives and Economic Growth: Are They Effective? A Review of the Iiterature. Washington, D.C.: Council of State Governments, Vol. 1.

"Wine Boycott Urged," The Oregonian. December 21, 1989.

"Wine Industry Seeks Millions in Aid from State," Northwest Grape Grower/Winemaker. November 1986, 7 .

"Wineries get Government's Go-Ahead to Tout Health Benefits," The Oregonian. August 17, 1993, FD4.

"Wineries Win Land Use Fight," Oregon Business. 19:2, 1983, 15 .

Wines \& Vines, Inc. Wines \& Vines Directory Issue. Annual December issue of periodical, annually.

Wolfe, Robert. 1991a. "Leading French Vintners Celebrate Their First Oregon-Made Wine," The Oregonian. April 11.

---. 1991b. "New Propagation Technique May Aid Phylloxera Battle," The wine Spectator. 16: July 15, 7.

Wolverton, Lincoln and Joan Wolverton. Salishan Vineyards Update. LaCenter, WA: Salishan Vineyards, irregular.

"Yakima Valley Vineyard Purchased by Sapporo Breweries," The Olympian. June 29, 1990, B8. 
Yarzebinsky, Joseph A. 1992. "Understanding and Encouraging the Entrepreneur," Economic Development Review. 10:1, 32-35.

Yates, Richard and Charity Yates. 1992. 1992 Washington State Yearbook: A Guide to Government in the Evergreen State. Seattle, WA: Information Press. 10th Edition.

Zimmerman, Joseph F. State and Local Government. New York: Barnes and Noble, 1962.

Zyman, John. 1983. Governments, Markets, and Growth. Ithica, NY: Cornell University Press.

PERSONAL INTERVIEWS

Government and Affiliated Persons

Interview with Julianne Allen, Executive Director, Oregon wine Advisory Board, in Portland, OR; January 29, 1993.

Interview with Carol Brant and Barrett MacDougall, Oregon Economic Development Department, in Salem, OR; July 19, 1991.

Interview with Clark C. Campbell, A\&D Systems Chief, Office of the Director, Office of Alcohol and Drug Abuse Programs, Oregon Department of Human Resources, in Salem, OR; July 19, 1991.

Interview with Barbara Driver, Oregon Travel Information Council, in Salem, OR; July 26, 1991.

Interviews with william Nelson amd staff, Oregon Winegrowers' Association, in Portland, OR; July 7, 1992 and November 1993.

Interview with Staff, Washington wine Commission, in Seattle, WA; August 16, 1991.

Personal Communication from Leigh Zimmerman, METRO, March 19, 1992 forwarding "18 for Recycling Program: Projects Recommended for Fourth Year - February 1992," with project summaries, Portland, OR, February 1992.

Wine-Makers and Winery Owners

Interviews with Dr. Fred Benoit, Chateau Benoit winery, in Carlton, OR; 1988-1989. 
Interviews with Jim Berneau, willamette Valley winery, in Portland and Salem, OR, February 1993.

Interviews with Cliff Blanchette, Hood River Vineyards, in Hood River, OR, 1985-1992.

Interview with Bill Blosser, Sokol-Blosser Winery, in Dundee, OR, March 1986.

Interviews with Joe and Pat Campbell, Elk Cove Vineyards, in Gaston, OR; 1980-1992.

Interview with Ron Chappel, Secret House Vineyards, in Eugene, OR; July 1993.

Interview with Karen Ford, Ashland Vineyards, in Portland, OR; September 16, 1992 .

Interviews with Virginia Fuller, Tualatin Vineyards, in Forest Grove, OR; 1980-1993.

Interviews with william Fuller, Tualatin Vineyards, in Forest Grove, OR; 1980-1993.

Interview with Bill Gordon, Gordon Brothers Cellars, in Pasco, WA; November 20, 1992.

Interview with Paul Hart, Rex Hill Vineyards, in Newberg, OR; July 1991.

Interviews with Trudy Kramer, Kramer Vineyards, in Gaston and Canby, OR; 1991-1992.

Interviews with Tom and Wendy Kreutner, Autumn Wing Vineyard, in Newberg, OR; 1989-1992.

Interviews with David Lett, The Eyrie Vineyards, in McMinnville, OR; 1990-1991.

Interview with Loie Maresh, Maresh Red Barn Vineyards, in Dundee, OR; July 12, 1992.

Interview with Stephen McCarthy, Clear Creek Distillery, in Portland, OR; January 14, 1993.

Interview with Scott Pontin, Pontin del Roza, in Prosser, WA; November 21, 1992 .

Interview with Bill Preston, Preston Winery, in Pasco, WA; November $20,1992$. 
Interviews with Harvey Shafer, Shafer vineyard Cellars, in Forest Grove, OR, 1985-1991.

Interview with Susan Sokol-Blosser, Sokol-Blosser Winery, in Portland, OR, November 2, 1991.

Interview with Ralph Stein, Yamhill vineyards, in Portland, OR, October 1991.

Interview with Carl Stevens, Oak Grove Winery, in Rickreall, OR, October 1992.

Interview with Mike Wallace, Hinzerling Vineyards, in Prosser, WA; November 21, 1992.

Interviews with Marilyn Webb, Bethel Heights Vineyard, in Salem, OR; 1984-1992.

Interview with Helmut Wetzel, Chateau Bianca Winery, in Dallas, OR; September 1992 .

Interviews with Iincoln and Joan Wolverton, Salishan

Vineyards, in La Center, WA; 1985-1992. 


\section{GLOSSARY}

Addiction: the state of having devoted oneself to the compulsive or habitual use of something, for example, narcotics, alcohol, overeating, or sex.

Administrative Rules: a codification of the rules by which an administrative agency interprets and implements policy and legislation enacted by that agency's overriding elective bodies.

Agribusiness: business enterprise engaged in producing, processing and/or marketing of food and non-food farm products.*

Agriculture: cultivation of land for a crop, or the raising of live stock.

Alcohol: an organic, hydro-carbon compound formed as a natural byproduct of fermentation; the intoxicant element of beer, liquor, and wine; C2H5OH; ethyl alcohol.

Appellation: a governmentally-recognized geographic region within which wine is produced and identified. The appellation is mandatory on labels for varietalidentified wines, and $100 \%$ of all the grapes must have come from that region; a method of identification and quality control.

AVA (American Viticultural Area): an appellation within the United States, designated by the BATF.

BATF (Bureau of Alcohol, Tobacco, and Firearms - Federal): a division of the U.S. Department of the Treasury, charged with regulating certain labeling, distribution, and financial aspects of alcohol production.

Beer: a fermented alcoholic beverage brewed from malt and flavored with hops; usually $38-88$ alcohol by volume.

Boutique wine: wine produced in small quantities, usually premium or ultra-premium, and sold through non-chain outlets.

Brandy: wine, part of which has been distilled and then added to the original wine fluid, raising its alcohol content to approximately 208-258 (40-50 Proof). 
Business: "any organization whose major purpose for existence is to earn a profit for its owners, including corporations, partnerships, and proprietorships that provide goods and/or services to their customers . . ."*

Commodity: any good available for sale.*

Commodity Commission: a promotional and marketing advisory body, providing advice to the ODA or WDA and representing industry interests. Commodity commissions are usually funded by levies or surcharges on the value of the agricultural commodity they represent. OWAB (see below), while not technically a commodity commission, functions as though it were.

Competition (pure): market condition in which there are a large number of sellers, the goods being sold are identical, and there is no obstruction to market entry to new sellers.*

Concentration Ratio: a measure of the total business in an industry concentrated in the largest firms.*

Cooperage: wooden or metal containers in which wine is produced and/or stored.

Crush: an industry term for the total volume of pre-wine grape liquid produced from crushing the grapes picked during a particular year's harvest. Crush units are English gallons.

Depressant: a substance or drug which has the effect of suppressing the activity of the human central nervous system.

Distillation: a chemical-mechanical process whereby alcohol is concentrated in a final liquid product. In the wine industry, distillation is used to produce brandy, fortified wine, and liqueurs.

Distributor: one who transports and distributes, from the wholesaler, a commodity or product to the retailer for marketing and sale.

Drug: (1) a substance used as medicine in the treatment of disease; (2) a narcotic.

EDC (Economic \& Development Council): a local, county-level counterpart to the EDD. Also "Economic Development Commission;" see Oregon Economic Development Department. 
Enology: variation of oenology.

Estate-Bottled: an indicator that wine was made from grapes grown from the winery's own vineyards, and located on land immediately adjacent to the winery. Such a wine cannot contain the juice of purchased grapes, or grapes grown at a remote site where the winemaker has less than 1008 knowledge and control of agricultural practices, such as the use of pesticides or herbicides to control insects or weeds.

Extension Service: a program of Oregon State University which "extends" advice and services throughout the state through county agents, in the areas of agriculture, forestry, home economics, energy and community development.

Farm Winery: a winery operated as a secondary farm process, utilizing fruit or grapes from the incident farm or local area farmers to produce wine as a supplement to the farm's primary crop production.

Farmer: one who cultivates land or crops, or raises livestock.

Fermentation: a bio-chemical process during which yeast cells produce enzymes, which in turn consume grape sugar to produce alcohol, carbon dioxide, and other byproducts.

Fortified wine: wine to which grain alcohol or brandy is added to increase its final alcohol content.

Freedom of Entry: the relative ease with which new sellers may enter a market.*

Fruit wine: wine which results from the fermentation of fruits other than grapes. Almost any fruit can be fermented to produce a fruit wine.

GCADAP (Governor's Council on Alcohol and Drug Abuse Programs, Oregon Department of Human Resources): a policy/advisory agency of the Oregon Department of Human Resources. The 11-member Council analyzes prevention, intervention and treatment programs and activities, and recommends a plan to coordinate statewide activities for implementation of its recommendations.

Grape: a fleshy, smooth-skinned fruit of the woody vine of the genus vitis. 
Harvest: an industry term for the total volume of grapes picked from a vineyard or collection of vineyards after a single growing season. Units are English tons.

Horticulture: the science of cultivating fruits, flowers, and other plants.

Impairment: in humans, a depressant effect on the central nervous system which inhibits reaction time and reaction to stimuli such as pain.

Industry: group of businesses that produce, distribute and sell the same or similar types of goods or services. Such a group will also include the infrastructure required for existence, and complimentary businesses needed to increase efficiency or market effectiveness.*

Infrastructure: underlying foundation of systems and organizations necessary for economic activity to function, such as roads, power systems, communications, public safety, and so on.*

Intoxicant: a substance or experience that intoxicates, especially through ingestion, any one or all of a series of altered mental and associated physical states ranging from exhilaration through stupefaction.

IRS: the United States Internal Revenue Service, an Executive Department subdivision charged with collecting taxes for the federal government.

Jug wine: wine which is usually sold in 1.5 or 2-liter bottles, for an average price of less than $\$ 4$ per 750 milliliters.

Juglar Cycle: an intermediate, major non-seasonal business cycle, representing fluctuations of price, production, employment, and growth with a frequency of nine to ten years. Each cycle is divided into expansion, levelout, contraction, and recovery phases. Short-frequency cycles are called Kitchin cycles, lasting about 40 months; long-frequency cycles are called Kondratieff cycles, lasting from 54 to 60 years.*

Kosher Wine: wine prepared in ways prescribed by Jewish ceremonial rites.

ICDC (Land Conservation and Development Commission) and Department: an administrative subdivision of the Executive Branch of the State of Oregon. Overseen by a 7-member commission, its function is to administer oregon's land-use planning laws and programs to protect 
resources and provide for managed, orderly development of those resources. See ORS Chapter 197.

Liquor: an alcoholic beverage made by distillation; usually 408- 508 alcohol by volume; also a generic term to include alcohol, spirits, wine or beer.

MADD (Mothers Against Drunk Driving): a non-profit association of individuals whose primary goal is to influence public policy and its application in the arena of alcohol abuse, specificaliy as it relates to automobile operation.

Manufacturer: a person or corporation who creates a product or ware from raw materials, by hand and/or utilizing machinery.

Market: the aggregation of the buying and selling of a commodity or service.

Market Share: ratio of a business' sales to total industry sales.*

Narcotic: a substance which relieves pain, and induces stupor or sleep. In extremes, can induce coma or death. Examples are opium, cocaine, heroin.

Neo-Prohibitionist: a term given by those in alcoholproduct industries for people and organizations seeking to limit or prohibit the sale and consumption of alcoholic beverages for primarily moral or valuerelated reasons.

OADAP (Office of Alcohol and Drug Abuse Programs, Oregon Department of Human Resources): a programmatic, nondivisional subdivision of the Oregon Department of Human Resources. Providing programmatic oversight of drug and alcohol programs, the office takes the State's lead in planning, contracting and/or regulating prevention and treatment activities. It also coordinates with other state agencies in producing a biennial Oregon State Plan for Alcohol and Drug Abuse Programs, and provides staffing for the Governor's Council on Alcohol and Drug Abuse Programs, and oversees expenditure of funds - including those from wine tax funds utilized for program purposes.

ODA (Oregon Department of Agriculture): an administrative sub-division of the Executive Branch of the State of Oregon. Overseen by a 10-member citizen State Board of Agriculture, its functions include agricultural policy development, marketing, development and introduction of new crops, disease control, inspection, labeling, 
testing, identification, regulation, and monitoring of food and processing elements, laboratory testing, soil and water conservation, and establishment/enforcement of standards. See ORS Chapters in the 500 series.

ODOR (Oregon Department of Revenue): an administrative subdivision of the Executive Branch of the State of Oregon. Among other duties, the Department collects excise taxes on grapes and wines, payroll taxes, and ensures equitable application of real and personal property taxes. See ORS Chapter 305.

ODOT (Oregon Department of Transportation): an administrative subdivision of the Executive Branch of the state of Oregon. Overseen by a 5-member Transportation Commission, the Department develops, establishes, and maintains state transportation policies and plans, and administers policies relating to highways, motor vehicles, and public transit. Among its subagencies are the Motor Vehicles Division. See ORS Chapter 184.

ODSP (Oregon Department of State Police): an administrative subdivision of the Executive Branch of the State of oregon. The agency was created as a rural highway patrol and assistant to local law enforcement agencies. One of its programs, REDDI (Report Every Drunk Driver Immediately) provides for reporting and apprehension of intoxicated drivers on state highways. See ORS Chapter 181 .

OEDD (Oregon Economic Development Department): an administrative subdivision of the Executive Branch of the State of Oregon. Advised by the 9-member oregon Economic Development Commission, the department is to develop, promote and maintain Oregon business opportunities and participate in the creation of jobs. Among its subdivisions are a Regional Strategies Unit, a Policy and Strategic Planning Office, a Private Sector Development agency, the Business Development Division, the Business Resources Division, the Tourism Division, and the International Trade Division. See ORS Chapter 184.

Oenology: the study of wine and wine making.

OHC (Oregon Health Council): an advisory council to the Oregon Department of Human Resources' Office of Health Policy (OHP). Consisting of a 16-member body, OHC prepares and annually revises a State Health Plan which identifies significant health case issues, and makes policy recommendations to the oregon Governor. See ORS 442.035 . 
OHD (Oregon Health Division): an administrative subdivision of the Oregon Department of Human Services. Its functions include analysis of health statistics, conducting special studies on disease, monitoring business activities that might impact citizens' health, overseeing public health standards and priorities, and providing health information and education. See ORS 184.830 .

OHP (Office of Health Policy, Oregon Department of Human Services): an administrative subdivision of the Oregon Department of Human Services. Its functions include coordination of multi-party health concerns, health planning, and policy analysis of critical health issues. One subordinate entity is the Health Policy Analysis section. It is not administratively on an equivalent basis with the seven divisions of the DHS.

OLA (Oregon Legislative Assembly): the legislative branch of the State of Oregon. Administrative departments, divisions and commissions provide biannual reports to various committees and subcommittees of the OIA, and together with industry representatives and citizen lobby groups attempt to introduce, change, or abolish statutes of the state created and passed by the OLA.

OLCC (Oregon Liquor Control Commission): an administrative subdivision of the Executive Branch of the State of oregon charged with overseeing the liquor laws of the State.

ORS: Oregon Revised Statutes, the laws of the State of Oregon.

OSF\&EC (Oregon State Fair and Exposition Center): an administrative subdivision of the Executive Branch of the State of Oregon, separate from any department. Overseen by a 5-member State Fair Advisory Commission, the Center is an exposition complex of halls, pavilions, an auditorium, barns, stables, a racetrack, a stadium, and a theater where each year a 2-week display of Oregon's harvests is held. In recent years, an Oregon wine-judging event held over several days has been a prominent part of the state Fair events. See ORS Chapter 565.

OSU (Oregon State University): a land-grant and sea-grant university, subdivision of the Oregon state system of Higher Education. The university provides an educational and research base for support of Oregon's agricultural resource, as well as forestry and marine resources. 
OSU ARF (Oregon State University Agricultural Research Foundation): an agricultural research program, funded through public and private sources, administered by OSU for the benefit and improvement of agricultural programs throughout the state.

OSU TTO (Oregon State University Technology Transfer Office): a program of adapting and transferring technological to the local level basic discoveries and

innovations in the fields of engineering, agriculture, and science.

OTSC (Oregon Traffic Safety Commission): an administrative and advisory subdivision of the Executive Branch of the State of Oregon. Overseen by a 5 -member board, the Commission plans, develops and conducts state-wide highway safety programs. See ORS 802.230 et seq. Under its guidance, a subordinate Governor's Advisory Committee on DUI (Driving Under the Influence) formulates programs to reduce the incidence of Oregonians driving under the influence of intoxicants. See Oregon Executive Order 83-20.

OWA (Oregon Winegrowers' Association): an industry professional/ support group for commercial winegrape growers and commercial winemakers.

OWAB (Oregon Wine Advisory Board), sometimes WAB: an administrative subdivision of the Oregon Department of Agriculture. Similar in nature and functions to a commodity commission, the OWAB (formerly Table wine Advisory Board) is overseen by an 11-member board, and is charged with encouraging and promoting research and experimentation into the ecological and viticultural aspects of winemaking, and promotion and marketing of Oregon wines. See ORS 576.775.

Phylloxera: a root louse which lives in the soil, attacking the rootlets of grape vines and eventually killing nonresistant root-stocks.

Policy: a plan, or course of action, designed to influence or direct courses of action and decisions.

Premium wine: wine which sells for between $\$ 4$ and $\$ 7$ per 750-milliliter bottle.

Prohibition: the period of history 1920-1933 when the manufacture, sale, or transportation of alcoholic beverages in the United States was prohibited under the 18th Amendment to the U.S. Constitution. States and 
local governments criminalized the possession and/or consumption of such beverages. The 18th Amendment was repealed by the 21st Amendment, passed by the US Congress in 1933 .

Proof: an indication of alcohol content, utilized by the liquor industry. One (1) proof is approximately 28 alcohol by volume. Table wine is between $10 \%$ ( 5 proof) and 148 ( 7 proof) alcohol by volume.

RCWA: Revised Code of Washington, Annotated, the laws of the State of Washington.

Regulation (by government): setting and/or maintaining legal conditions by a unit or units of government to ensure for consumers the fair, safe, and efficient operation of businesses, industries, or systems of enterprise.*

Reserve: wine from a crush that the winemaker has set aside, or reserved, for additional or different treatment than the rest of the wine produced from that crush.

Retailer: a merchant who sells in small quantities, usually to the ultimate customer who will consume the product.

Risk: exposure of an investor or business person to possible gain or loss of money, usually defined in terms of uncertainty and potential change in economic conditions (consumer tastes or technology), natural conditions (drought, inundation, volcanic activity), political conditions (revolution, change of elected officials or philosophy), or administrative conditions (regulatory change, economic development support).*

Root-Stock: a grapevine base, including roots and central stem, grown for various characteristics (including disease resistance and resistance to the root louse Phylloxera) and onto which the producing stem(s) of the grapevine are grafted.

SADD (Students Against Drunk Driving): a non-profit association of individuals whose primary goal is to influence public policy and its application in the arena of alcohol abuse, specifically as it relates to automobile operation.

Table Wine: an unfortified wine suitable for, and sale packaged for use with, a meal.

Tasting Room: a sales/retail outlet, usuaily physically located at a winery, designed to give visitors an opportunity to taste a winery's products or purchase 
other wine-related items.

TIC (Travel Information Council): an 11-member advisory board to the ODOT, which oversees the administration of the Oregon Highway Logo and Tourist Oriented Directional Signing programs. It also operates 13 information kiosks located throughout the state, particularly close to interstate border highway crossings. See ORS 377.800 et seq.

Trademark: a symbol, or signature, of the winery producing a particular label.

Ultra-premium wine: wine that sells for more than $\$ 7$ per 750-milliliter bottle.

USDA (United States Department of Agriculture): a subdivision of the Executive Branch of the federal government, charged with aiding and assisting states in developing and marketing agricultural products; a Statistics Service maintains data bases in most states on vineyards and winery production, in cooperation with local Departments of Agriculture and commodity commissions.

Varietal: characterizing a biological variety, a biological subdivision; among winegrapes grown in the Pacific Northwest, the grape varietals include Pinot Noir, Pinot Gris, Pinot Meunier, Gewurztraminer, Chardonnay, White Riesling, Cabernet Sauvignon, Sauvignon Blanc, Mueller-Thurgau, Marechal Foch, Merlot, Chenin Blanc, Early Muscat, Muscat Ottonel, and Sylvaner. Oregon wines must be either named after their varietals, or a trade name developed specifically for that wine; they may not be named after appellations of other states or countries ("Burgandy," "Champagne," "Chablis," etc.).

Vin ordinaire: an inexpensive, (usually) red table wine.

Vine: a single grape-growing plant.

Vineyard: an agricultural plot of land where grape vines grow. Some vineyards are located on the same site as the winery, while others are remote from the site where the wine is produced.

Vintage: the year in which a wine is produced, the same year in which the grapes were harvested. In Oregon, for a bottle's label to carry a particular vintage year, at least $95 \%$ of the grapes used to produce that wine must have been harvested in the stated year; a method of identification and quality control. 
Vintner: a wine merchant, or a maker of wine.

Viticulture: cultivation of grapes.

WDA (Washington Department of Agriculture): an administrative and regulatory subdivision of the State's Executive Department, charged with regulating agricultural development, production and processing, and for consumer protection. See RCWA Chapter 43.23.

WDCED (Washington Department of Commerce and Economic Development): an administrative subdivision of the State's Executive Department, responsible for economic development throughout the state. Programmatic divisions include trade, travel, industry, small business, and research. Part of its responsibility is to carry out State economic Policy as set forth in RCWA Chapter 43.21H. See RCWA 43.31 and 70.98 .

WDOT (Washington Department of Transportation): an administrative subdivision of the State's Executive Department, charged with overseeing public highway and rail systems, ride-sharing programs, administration of federal and state capital improvement funds, and highway signage. See RCWA Chapter 47.01.

Wholesaler: a merchant middleman who sells chiefly to retail outlets or commercial or institutional entities for direct end-use or retail sales.

Wine Library: a winery's or research organization's collection of wines, ordered in such a way as to facilitate study of the aging characteristics of varietal wines.

Wine: the fermented juice of various kinds of grapes, or of other fruits or plants.

Winemaker: the individual in charge of producing a finished wine product from grape fruit.

Winery: a processing site where wine is made.

WLCB (Washington Liquor Control Board): an administrative agency of the state Executive Branch charged with overseeing the liquor laws of the state. See RCWA Chapter 66 .

WSP (Washington State Patrol): Washington's state police agency, an administrative subdivision of the State's Executive Department. A principal function is 
enforcement of traffic safety rules. See RCWA Chapter 43.43 .

WSU (Washington State University): a land-grant university, subdivision of the Washington State system of Higher Education. The university provides an educational and research base for support of Washington's agricultural resources, including the wine industry. See RCWA 28B. 30 .

WTSC (Washington Traffic Safety Commission): a nonadministrative subdivision of the WDOT, composed of six state elected and appointed Executive Department officials and three others from outside the Department. Its function is to plan education, training, public information and enforcement programs to promote safe driving habits and reduce highway accidents and injuries. See RCWA 43.59.

WWC (Washington wine Commission): an administrative subdivision of the Washington Department of Agriculture. Similar in nature and functions to a commodity commission, the WWC is charged with encouraging and promoting research and experimentation into the ecological and viticultural aspects of winemaking, and promotion and marketing of Washington wines. Its 11 members are appointed: five from wine producers, five from wine grape growers, and one wine wholesaler. See RCWA Chapter 15.88.

* Adapted from Douglas Greenwald et al. (Eds.), The MCGraw-Hill Dictionary of Modern Economics (New York, McGraw-Hill, 1983). 3rd Edition. 